University of Michigan Law School

University of Michigan Law School Scholarship Repository

\title{
Expungement of Criminal Convictions: An Empirical Study
}

\author{
J.J. Prescott \\ University of Michigan Law School, jprescott@umich.edu \\ Sonja B. Starr \\ University of Michigan Law School, sbstarr@umich.edu
}

Available at: https://repository.law.umich.edu/articles/2165

Follow this and additional works at: https://repository.law.umich.edu/articles

Part of the Criminal Law Commons, Labor and Employment Law Commons, and the Law and Society Commons

\section{Recommended Citation}

Prescott, J.J. "Expungement of Criminal Convictions: An Empirical Study." Sonja B. Starr, co-author. Harv. L. Rev. 133, no. 8 (2020): 2460-555.

This Article is brought to you for free and open access by the Faculty Scholarship at University of Michigan Law School Scholarship Repository. It has been accepted for inclusion in Articles by an authorized administrator of University of Michigan Law School Scholarship Repository. For more information, please contact mlaw.repository@umich.edu. 


\section{HARVARD LAW REVIEW}

(1) 2020 by The Harvard Law Review Association

\section{ARTICLE \\ EXPUNGEMENT OF CRIMINAL CONVICTIONS: AN EMPIRICAL STUDY}

\section{J.J. Prescott \& Sonja B. Starr}

INTRODUCTION

I. Expungement Policies AND RELATEd ReSEARCH .................................................24 2468

A. The Economic and Legal Aftermath of a Criminal Conviction.................................2468

B. Sealing of Criminal Records: The Legal and Policy Landscape ...............................2472

C. Research Questions and Existing Empirical Research on Expungement................2476

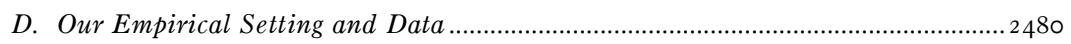

II. The Uptake Gap: Who Seeks And Receives Expungements?.......................24 246

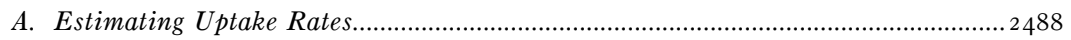

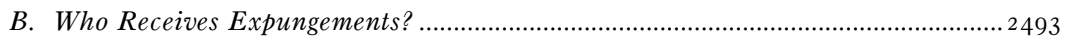

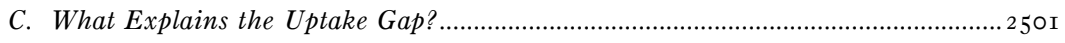

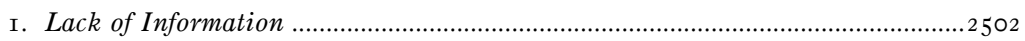

2. Administrative Hassle and Time Constraints ...................................................2502

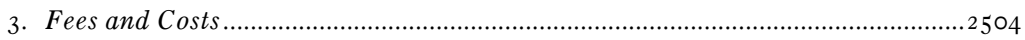

4. Distrust and Fear of the Criminal Justice System .............................................2504

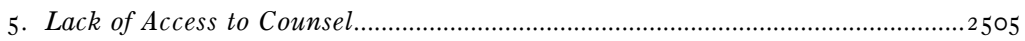

6. Insufficient Motivation to Pursue Expungement ....................................................2506

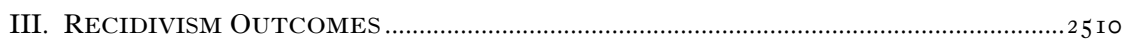

A. Recidivism Among Expungement Recipients .............................................................. 5 I I

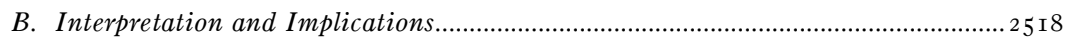

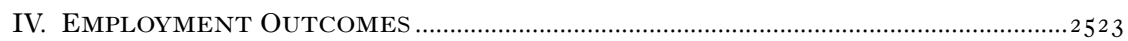

A. Employment and Wage Trajectories for Expungement Recipients............................2524

B. Interpretation: Expungement Effect, Motivation, or Mean Regression? .................2533

V. OTHER OBJECTIONS To EXPUNGEMENT LAWS ...................................................254

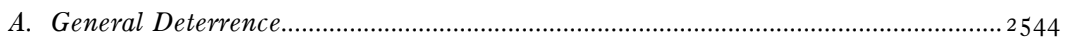

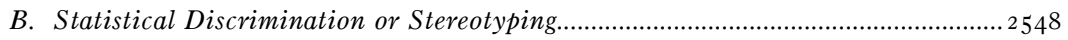

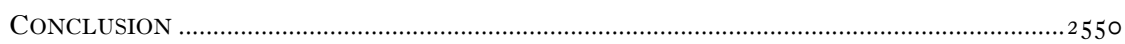




\title{
EXPUNGEMENT OF CRIMINAL CONVICTIONS: AN EMPIRICAL STUDY
}

\author{
J.J. Prescott and Sonja B. Starr*
}

Laws permitting the expungement of criminal convictions are a key component of modern criminal justice reform efforts and have been the subject of a recent upsurge in legislative activity. This debate has been almost entirely devoid of evidence about the lawe' effects, in part because the necessary data (such as sealed records themselves) have been unavailable. We were able to obtain access to de-identified data that overcome that problem, and we use it to carry out a comprehensive statewide study of expungement recipients and comparable nonrecipients in Michigan. We offer three key sets of empirical findings. First, among those legally eligible for expungement, just $6.5 \%$ obtain it within five years of eligibility. Drawing on patterns in our data as well as interviews with expungement lawyers, we point to reasons for this serious "uptake gap." Second, those who do obtain expungement have extremely low subsequent crime rates, comparing favorably to the general population - a finding that defuses a common publicsafety objection to expungement laws. Third, those who obtain expungement experience a sharp upturn in their wage and employment trajectories; on average, within one year, wages go up by over $22 \%$ versus the pre-expungement trajectory, an effect mostly driven by unemployed people finding jobs and minimally employed people finding steadier or higher-paying work.

\section{INTRODUCTION}

$\mathrm{T}$ oday, somewhere between I9 and 24 million Americans have felony conviction records, ${ }^{1}$ and an unknown - but presumably much

* Henry King Ransom Professor of Law and Henry M. Butzel Professor of Law, respectively, and Co-Directors of the Empirical Legal Studies Center, University of Michigan Law School. The authors gratefully acknowledge the generous financial support of the National Science Foundation (Award No. SES I023737) and the assistance of several Michigan state agencies in obtaining data: the State Police; the Workforce Development Agency; the Unemployment Insurance Agency; the Department of Technology, Management and Budget; and the State Court Administrative Office. We are also grateful to Miriam Aukerman, Jeff Morenoff, and David Harding for early advising, to conference and workshop participants at the NBER Summer Institute, Harvard Law School, the University of Michigan, the Center for American Progress, and the Michigan District Judges Association for helpful feedback, to colleagues at Michigan and elsewhere for fruitful discussions, and to all the experts whose interviews and emails are cited herein for sharing their insights. We are indebted to Margaret Love and David Schlussel for their advice and support on this project, and we thank the many research assistants who contributed during the project's ten-year history, including Patrick Balke, Grady Bridges, Gabriella D'Agostini, David Do, Haley Dutch, Jonathan Edelman, Nathaniel Givens, Seth Kingery, Rami Krispin, Elena Malik, German Marquez Alcala, Charlotte McEwen, Chris Pryby, Chelsea Rinnig, Zehra Siddiqui, and especially Simmon Kim for his extensive efforts.

1 See The Economic Impacts of the 2020 Census and Business Uses of Federal Data: Hearing Before the J. Econ. Comm., I I6th Cong. I 2 (2019) (statement of Nicholas Eberstadt, Henry Wendt Chair in Political Economy, American Enterprise Institute); Sarah K.S. Shannon et al., The Growth, Scope, and Spatial Distribution of People with Felony Records in the United States, I948-20I0, 54 DEMOGRAPHY I795, I806 (2017). When arrests are added, 75 million Americans - a third of adults - have criminal records. See FBI, NOvEMBER 2018 Next 
larger - number have misdemeanor conviction records. ${ }^{2}$ In recent years, policymakers, civil rights advocates, and scholars have paid increasing attention to the substantial barriers to employment, ${ }^{3}$ housing, ${ }^{4}$ and social integration ${ }^{5}$ that these records can pose, not to mention the hundreds of collateral legal consequences that typically flow from criminal convictions, such as restrictions on public-benefits eligibility and occupational licensing. ${ }^{6}$ Taken together, these hurdles have been described as amounting to a "new civil death," and on a collective scale, this phenomenon magnifies racial disparities in employment and other outcomes due to disparities in the distribution of criminal records. For all these reasons, a core part of this century's emergent criminal justice reform movement has been a search for effective policy levers to mitigate the reentry barriers faced by people with criminal records. This effort is picking up steam in virtually every corner of the country, with two-

GENERATION IDENTIFICATION (NGI) SYSTEM FACT SHEET I (20I8), https://www.fbi.gov/filerepository/ngi-monthly-fact-sheet/view [https://perma.cc/5 KQJ-UBL 5 ].

2 No studies currently document the total number of Americans with misdemeanor convictions. However, statistics collected between 2008 and 2016 indicate that misdemeanors routinely make up over $70 \%$ of a state's criminal caseload. Megan Stevenson \& Sandra Mayson, The Scale of Misdemeanor Justice, 98 B.U. L. REV. 73I, 746 n.8I (2018).

3 See, e.g., Nan Astone, Michael Katz \& Julia Gelatt, Urban Inst., InNovations in NYC Health \& Human Services Policy: Young Men's Initiative 6 (20I4), https://www.urban.org/sites/default/files/publication/3265 I/4I 3057-Innovations-in-NYC-Healthand-Human-Services-Policy-Young-s-Men-s-Initiative.PDF [https://perma.cc/V954-Y 23 W]; Fact Sheet: President Obama Announces New Actions to Promote Rehabilitation and Reintegration for the Formerly-Incarcerated, OBAMA WhITE HOUSE ARCHIVES (Nov. 2, 2015), https://obamawhitehouse.archives.gov/the-press-office/2015/I I/o2/fact-sheet-president-obamaannounces-new-actions-promote-rehabilitation [https://perma.cc/F8gL-69 $\left.\mathrm{K}_{4}\right]$.

4 See, e.g., Anne Morrison Piehl, Hamilton Project, Putting Time Limits on the Punitiveness of the CRiminal Justice System 9 (20I6), https://www. hamiltonproject.org/assets/files/reducing_punitiveness_piehl_policymemo.pdf [https://perma.cc/ XQ5P-DWKF]; MARIE Claire Tran-LEung, SARgent Shriver NaT'L Ctr. ON POVERTy Law, When Discretion Means Denial: A National Perspective on Criminal RECORDS BARRIERS TO FEDERALlY SUBSIDIZED HOUSING I (20I5), https://www. povertylaw.org/wp-content/uploads/2019/og/WDMD-final.pdf [https://perma.cc/GV7K-GSEV].

5 See, e.g., Amy L. Solomon, In Search of a Job: Criminal Records as Barriers to Employment, NIJ J., June 20I2, at 42, 44, https://www.ncjrs.gov/pdffiles I/nij/238488.pdf [https://perma.cc/2 T6Y-TK 9 F]; Letter from Eric H. Holder, Jr., U.S. Attorney Gen., to State Attorneys Gen. (Apr. I8, 20I I) (available

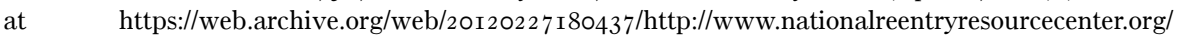
documents/0000/ı088/Reentry_Council_AG_Letter.pdf).

6 See Margaret Colgate love et al., Collateral Consequences of Criminal CONvictions: LAW, POLICY AND PRACTICE $\S$ I:I2, 2:8, 2:75, 6:I6 (20I8); see also Gabriel J. Chin, The New Civil Death: Rethinking Punishment in the Era of Mass Conviction, I6o U. PA. L. REV. I789, I8II-I4 (2012); Alexandra Natapoff, Misdemeanor Decriminalization, 68 VAND. L. REV. 1055, 1089-94 (2015). See generally National Inventory of Collateral Consequences of Conviction, CSG JUST. CTR., https://niccc.csgjusticecenter.org [https://perma.cc/ ${ }_{79}{ }_{9}{ }_{-5} \mathrm{PFN}$ ] [hereinafter CSG Inventory].

7 Chin, supra note 6, at I 790; see also JAMEs B. JACOBS, THE ETERNAL CRIMINAL RECORD 4 (2015) (observing that criminal records are "for life" and "there is no statute of limitations"). 
thirds of U.S. states adopting one or more such policies in $2018,{ }^{8}$ and fortythree states, the federal government, and the District of Columbia passing an "extraordinary I 53 laws" aimed at this problem in 2019.9

Perhaps the policy levers with the greatest theoretical potential to improve reentry outcomes are laws that allow criminal conviction records to be wholly expunged or, at least, sealed from public view. We will refer to such laws collectively as "expungement laws," and this process as "expungement," although such shorthand elides some differences. ${ }^{10}$ Expungement offers the possibility of sweeping aside a wide range of legal and socioeconomic consequences at once; these laws typically authorize individuals to apply for jobs, housing, schools, and benefits as though their convictions did not exist.

Today, a substantial majority of U.S. states provide some form of expungement procedure for otherwise-valid adult convictions. ${ }^{11}$ Many states have recently adopted, or are presently considering, new expungement laws or expansions to existing ones. ${ }^{12}$ For example, New Mexico,

8 A major report by the Collateral Consequences Resource Center documents the "extraordinary number of laws passed [by thirty-two states, the District of Columbia, and the U.S. Virgin Islands] in 2018 aimed at reducing barriers to successful reintegration for individuals with a criminal record," calling it the "most productive legislative year since a wave of 'fair chance' reforms began in 2013." Press Release, Collateral Consequences Resource Center, New Report on 2018 Fair Chance and Expungement Reforms (Updated) (Jan. Io, 20I9), https://ccresourcecenter. org/20I $/$ / I/Io/press-release-new-report-on-20 I 8-fair-chance-and-expungement-reforms/\#more-18004 [https://perma.cc/4AGU-6CH5]; see also MARGaret LOVE \& DAVID SCHLUSSEL, COLlateraL CONSEquenCES RES. CTR., REDUCING BARRIERS TO REINTEGRATION: FAIR CHANCE AND EXPUNGEMENT REFORMS IN 20I8, at 2-3 (20I9), https://ccresourcecenter.org/wp-content/ uploads/20I9/or/Fair-chance-and-expungement-reforms-in-2018-CCRC-Jan-20I 9.pdf [https://perma.cc/9QA $5-9$ PMM].

9 Margaret love \& David Schlussel, Collateral Consequences Res. Ctr., PATHWAys to REINTEGRATION: CRIMINAL RECORD REFORMS IN 20I9, at I-2 (2020), http://ccresourcecenter.org/wp-content/uploads/2020/02/Pathways-to-Reintegration_CriminalRecord-Reforms-in-20I9.pdf [https://perma.cc/35MG-734Y].

10 The details vary by jurisdiction, and many advocates use various terms such as "expungement," "sealing," and "set-aside" interchangeably. Typically, a true "expungement" legally eliminates the record from the state's perspective. "Sealing" maintains the record for some limited state purposes (for example, law enforcement investigations of future crimes) but insulates it from public view.

11 Two useful online resources contain periodically updated collections of these laws; at our last check, we found slightly different information at the two sites, but both include close to forty states with some form of expungement law for valid, nonpardoned, and nonvacated adult criminal convictions. See 5o-State Comparison: Expungement, Sealing \& Other Record Relief, Collateral CONSEQUENCES RESOURCE CTR., https://ccresourcecenter.org/state-restoration-profiles/5o-statecomparisonjudicial-expungement-sealing-and-set-aside [https://perma.cc/JA4B-2HUD] [hereinafter CCRC State Survey]; States, Clean Slate Clearinghouse, https://cleanslateclearinghouse. org/compare-states [https://perma.cc/94VU-UPRD].

12 For example, in 2018 alone, twenty states passed twenty-nine bills expanding expungement eligibility. LOVE \& SCHLUSSEL, supra note 8, at 2 . In 20I9, there was still further activity, with " 3 I states and D.C. enact[ing] no fewer than 67 bills creating, expanding, or streamlining record relief," and twenty states "authoriz[ing] diversion programs that produce non-conviction dispositions newly eligible for record-clearing under existing law." LOVE \& SCHLUSSEL, supra note 9, at Io. Fifteen of these states took "incremental" steps, and five made more dramatic eligibility-enhancing changes. Id. at 
for the first time, passed a law in 2019 to make a petition-based expungement process available, ${ }^{13}$ and it is not alone. ${ }^{14}$ In 2018 , Pennsylvania became the first state to adopt a sweeping program of automatic expungement of adult criminal convictions - specifically, nonviolent misdemeanors after ten crime-free years. ${ }^{15}$ In 2019 , Utah, New Jersey, and California also enacted automatic expungement laws, ${ }^{16}$ which are more ambitious in some ways. For example, Utah has only a five-year waiting period in some instances, ${ }^{17}$ and California's recent legislation has even shorter waiting periods (none in some cases) and encompasses minor felonies as well as misdemeanors, although the law only operates prospectively. ${ }^{18}$ The New Jersey law extends automatic expungement

IO-I7. We note that many of the new or amended laws have features that roughly parallel the Michigan law we study, and therefore, our work can be useful in predicting the likely consequences of these reforms.

13 Danny W. Jarrett et al., New Mexico Adopts Ban-the-Box, Expungement Laws, JACKSONLEWIS (Apr. 22, 20I9), https://www.jacksonlewis.com/publication/new-mexico-adoptsban-box-expungement-laws [https://perma.cc/96SE-ABY9]. The expungement law went into effect on January I, 2020. Id.

14 See Love \& SChlussel, supra note 9, at i4 ("New Mexico, North Dakota, Delaware, West Virginia, and Colorado made particularly dramatic changes to their petition-based systems to extend eligibility for relief to a range of non-conviction and conviction records. None of the first four states had previously authorized relief for felony-level offenses, and Colorado had authorized sealing only for drug convictions. The comprehensive schemes enacted by North Dakota and New Mexico are noteworthy as the first laws in those states to authorize sealing of adult criminal records. Both states extend relief to most felonies, but they also require the applicant to pay a filing fee and make the case for relief at a court hearing. (North Dakota courts may dispense with the hearing if the prosecutor agrees.)").

15 Faith Karimi, Pennsylvania Is Sealing 30 Million Criminal Records as Part of Clean Slate Law, CNN (June 28, 20I9, 4:46 AM), https://www.cnn.com/20I 9/06/28/us/pennsylvania-clean-slatelaw-trnd/index.html [https://perma.cc/5XVN-RFFE]. Felonies, as well as violent and certain other serious misdemeanors, are ineligible for automatic expungement. I8 PA. CONS. STAT. § 9I22.3(a), (b) (20I9). But such offenses are still potentially eligible for expungement by petition. Id. § 9I 22.3 (c).

16 Jessica Miller, Utah Lawmakers Pass the "Clean Slate" Bill to Automatically Clear the Criminal Records of People Who Earn an Expungement, SALT LAKE TRIB., (Mar. I6, 20I9) https://www.sltrib.com/news/2019/03/r4/utah-lawmakers-pass-clean [https://perma.cc/HVV7-VFE6]; Press Release, State of N.J., Governor Murphy Signs Major Criminal Justice Reform Legislation (Dec. I8, 20I9), https://www.nj.gov/governor/news/news/562019/approved/201912 I8a.shtml [https:// perma.cc/V5YE-RK8F]; CCRC Staff, California Becomes Third State to Adopt "Clean Slate" Record Relief, Collateral Consequences Resource CTR. (Oct. io, 20i9), http://ccresourcecenter. $\mathrm{org} / 20 \mathrm{I} / \mathrm{I} / \mathrm{s} / \mathrm{ro} / \mathrm{california}$-becomes-third-state-to-adopt-clean-slate-record-relief [https://perma.cc/8 5 C-XSRJ].

17 UTAH CODE ANN. § 77-40-IO2(5)(a)(iii)(A) (LexisNexis 2020). The waiting periods are six years for more serious misdemeanors and seven years for certain drug crimes. Id. \$§77-40IO2(5)(a)(iii)(B)-(C).

18 CAL. Penal CODE $\S \mathrm{I} 203.425(\mathrm{a})(2)(\mathrm{E})$ (West 2020) (stating that automatic relief is available only for convictions "on or after January I, 202 I," and only for misdemeanors, infractions, and offenses resulting in a sentence of probation). For all crimes resulting in probation sentences (even felonies), relief is automatic after completing probation, with no further waiting period. Id. $\S \mathrm{I} 203.425(\mathrm{a})(2)(\mathrm{E})(\mathrm{i})$. Automatic expungement is also available for all misdemeanors, even those resulting in jail time; in that case the waiting period is one year. $I d$. $\S \mathrm{I} 203.425(\mathrm{a})(2)(\mathrm{E})(\mathrm{ii})$. 
to some felonies as well as misdemeanors, without limits as to the number of convictions expunged, after a ten-year period with no subsequent convictions. ${ }^{19}$ Other states may soon follow suit. ${ }^{20}$ More typically, expungement laws require individuals to go through a judicial process to apply for relief, usually giving judges the discretion to deny the petition. Many states have stringent eligibility requirements as to crime type or severity or the number of convictions on the individual's record, and many have waiting periods. ${ }^{21}$

Despite the considerable legislative ferment and the excitement that surrounds these "Clean Slate" initiatives in the civil rights and criminal justice reform worlds, what has been missing from the debate is hard evidence about the effects and true potential of conviction expungement laws. Empirical studies in this area have been difficult to carry out. Expunged criminal records are, obviously, not typically available to study - and other relevant outcome data, such as wage information or employment status, are also protected by privacy laws. While there are many persuasive theoretical reasons to believe that expungement laws will have large and important effects across many domains, ${ }^{22}$ the dearth of empirical evidence is a significant hindrance to reform and experimentation. It leaves policymakers almost entirely in the dark.

In this Article, we present the results of an unprecedented statewide study that overcomes existing limitations on research on expungement and seeks to fill various policy-relevant gaps in our empirical knowledge. Pursuant to a data-sharing agreement with the State of Michigan, we were able to obtain complete, de-identified criminal records from the Michigan State Police (MSP) on all individuals who had received conviction expungements (known as "set-asides" in Michigan) as of March 20I4, as well as full criminal history records for much larger comparison groups of individuals with convictions that were not expunged. In addition, the state matched these criminal histories with detailed wage and employment

19 Criminal History Record Information - Expungement, 2019 N.J. Sess. Laws Serv. I I-I 2 (West) (to be codified at N.J. STAT. ANN. $\S_{2} \mathrm{C}: 5_{2}-5.3$ ). In the immediate term, this relief is petition based, but a task force has been directed to develop an automated process. Id. at $\mathrm{I}_{2}-\mathrm{I} 4$ (to be codified at N.J. STAT. ANN. § 2 C:52-5.4).

20 See, e.g., Expungement Bill Package Passes House with Overwhelming Bi-partisan Support, MicH. HOUSE DEMOCRATS (Nov. 22, 20I9), https://housedems.com/article/expungement-billpackage-passes-house-overwhelming-bi-partisan-support [https://perma.cc/2PWU-2ZVL]; Kelan Lyons, Winfield to Swap Out Lamont's Clean Slate Bill with a Broader Measure, CT MIRROR (Feb. 26, 2020), https://ctmirror.org/2020/02/26/winfield-to-swap-out-lamonts-clean-slate-bill-for-a-broader-measure [https://perma.cc/2 AX $2-B M W Z]$

21 See sources cited supra note I I see also infra section I.B, pp. $2472-76$ (describing this legal landscape in more detail).

22 See, e.g., Brian M. Murray, Unstitching Scarlet Letters?: Prosecutorial Discretion and Expungement, 86 FORDHAM L. REV. 282 I, 2824-26 (20I8); Amy Myrick, Facing Your Criminal Record: Expungement and the Collateral Problem of Wrongfully Represented Self, 47 LAW \& SOC'Y REV. 73, 74 (20I3). 
data for the same individuals from the state's unemployment insurance program, sharing these data with us as well.

Michigan is an ideal setting in which to study expungement laws: it is a large, diverse state with criminal justice challenges typical of the United States today. Moreover, the version of Michigan's expungement law we study has many of the common features of a petition-based record-clearing law, and it applies to a diverse set of records (e.g., violent/nonviolent, misdemeanor/felony), carries a fairly short waiting period, has relatively straightforward eligibility rules, and went untouched for more than two decades, allowing us to study results over time.

We use our unique data to investigate a number of interrelated empirical questions, which can be grouped into three main areas of inquiry. First, we examine the critical question of the "uptake rate": the rate at which those who are legally eligible for expungements actually receive them. ${ }^{23}$ We find that Michigan's expungement uptake rate is discouragingly low; our best estimate is that only $6.5 \%$ of all eligible individuals receive an expungement within five years of the date at which they first qualify for one. ${ }^{24}$ To better understand the uptake process, we examine the characteristics of expungement recipients and their offenses and assess whether some characteristics are predictive of uptake by eligible individuals. We then use these data, plus interviews with Michigan expungement lawyers and advocates for people with criminal records, to inform a discussion of why people might not apply for expungements despite their potential benefits.

Second, we investigate expungement recipients' subsequent criminal offending. ${ }^{25}$ We find very low rates of recidivism: just 7.I \% of all expungement recipients are rearrested within five years of receiving their expungement (and only $2.6 \%$ are rearrested for violent offenses), while reconviction rates are even lower: $4.2 \%$ for any crime and only $0.6 \%$ for a violent crime. Indeed, expungement recipients' recidivism rates compare favorably with those of the Michigan population as a whole. ${ }^{26}$ We do not claim that these low rates are necessarily because of expungements, although there are several channels by which expungement receipt could potentially contribute to lower recidivism risk. Another likely explanation is that people who have limited criminal records and have gone at least five years since their last conviction are simply very low risk to begin with. This finding is consistent with the broader empirical literature on patterns of desistance from crime. Whatever the cause, the low

\footnotetext{
23 See infra Part II, pp. 2486-25 10.

24 Although our data do not identify unsuccessful applicants, it is clear from follow-up inquiries with the Michigan State Police that the low uptake rate can be primarily attributed to individuals' failure to apply, rather than to denials of applications by judges. See infra section II.C.6, pp. 2506-2 IO.

25 See infra Part III, pp. 25 IO-23.

26 See infra p. $25 \mathrm{I} 4$.
} 
recidivism rates we observe help to defuse an otherwise potentially convincing policy argument against expungement laws: that the public (including employers and landlords) has a safety interest in knowing about the prior records of those with whom they interact.

Third, we examine the employment consequences of criminal record expungement. ${ }^{27}$ After accounting for an individual's prior employment and wage history, as well as broader changes in the economy, we find that expungement recipients experience considerable gains shortly after receipt. Within one year, on average, an individual's odds of being employed (earning any wages at all) increase by a factor of I.I3; their odds of earning at least $\$ \mathrm{I}$ oo/week (a slightly more demanding employment measure) increase by a factor of I.23; and their reported quarterly wages increase by a factor of I.23 (and are sustained in subsequent years). These results suggest that those with expunged records gain access to more and better-paying jobs. To be sure, one has to be cautious about drawing causal inferences here; it is very possible that some of the gains come about because people choose to seek expungement at a time that they are especially motivated to seek improvements in their economic situation. Nonetheless, our data and other supporting evidence give us some confidence that at least a large fraction of the improvement that we observe stems from the clean record itself.

We provide background on expungement laws, existing relevant empirical research, and our research setting (including our data and their limitations) in Part I. We then present the three major components of our work - our analyses of expungement uptake, the recidivism rates among expungement recipients, and the relationship between expungement and subsequent employment outcomes - in Parts II, III, and IV, respectively. In Part $\mathrm{V}$, we respond to two potential objections to expungement, which might, if accurate, influence the policy takeaways of our empirical results. In the Conclusion, we address policy implications and consider future research possibilities.

Our findings tell a good news/bad news story: when expungement is not automatic (and takes time, effort, and even money to apply), only a very small share of the people eligible for relief actually apply for and receive an expungement - but those who do experience clear improvements in economic outcomes and pose little public-safety risk. Taken together, these conclusions have a clear policy upshot: they support the expansion of expungement availability, an easing of the procedural hurdles associated with seeking expungement, and, in particular, the emerging movement to make expungement occur automatically after a period of time, rather than after an application process.

27 See infra Part IV, pp. 2523-43. 


\section{EXPUnGEMENT POLICIES AND RELATED RESEARCH}

Several large bodies of scholarly research, as well as active policy debates and commentary, inform and motivate our study. In section I.A, we describe the many hurdles people with public criminal records face; paring back these hurdles is the core policy motivation for expungement laws and efforts to expand them. In section I.B, we add some further detail to the Introduction's description of the current legal and policy landscape surrounding expungement. In section I.C, we discuss the very limited empirical research that exists on expungement and identify the key unanswered empirical questions that we seek to address. In section I.D, we turn to our specific empirical setting, describing Michigan's expungement law and the data that we use in our study.

\section{A. The Economic and Legal Aftermath of a Criminal Conviction}

The consequences of criminal convictions do not end when people convicted of crimes complete their formal sentences. For many individuals, punishments such as probation, fines, and even incarceration may be dwarfed in importance by what comes next: exclusion from employment, obstacles to social integration, and a vast array of collateral legal consequences that often last a lifetime. ${ }^{28}$ A growing body of academic research documents the scope, ubiquity, and size of these hurdles. ${ }^{29}$

First, people with criminal records face serious employment barriers - indeed, these barriers may exceed those facing any other disadvantaged group. ${ }^{30}$ While many aspects of these individuals' backgrounds, as well as the interruptions to work and education experienced by those who are incarcerated, may put them at greater risk of unemployment than the general population, ${ }^{31}$ the criminal record itself also

28 See Sarah B. Berson, Beyond the Sentence - Understanding Collateral Consequences, NIJ J., Sept. 20I3, at 25, 25 https://www.ncjrs.gov/pdffilesi/nij/24I927.pdf [https://perma.cc/C2FM8GF 3]; CSG Inventory, supra note 6; see also LOVE ET AL., supra note 6, §§ I:I I-I:I 2, 2:44.

29 See, e.g., Pew Charitable TrS., COllateral Costs: InCARCERATION's EFFECT ON ECONOMIC MOBILITY (20Iо), https://www.pewtrusts.org/ /media/legacy/uploadedfiles/pcs_ assets/20Io/collateralcostsipdf.pdf [https://perma.cc/B 7 XB-MCEN]; Anastasia Christman \& Michelle Natividad Rodriguez, Research Supports Fair Chance Policies, NAT'L EmP. L. ProJECT (Aug. I, 20I6), https://www.nelp.org/publication/research-supports-fair-chance-policies [https:// perma.cc/V7GG-YQNT].

30 See Harry J. Holzer et al., Perceived Criminality, Criminal Background Checks, and the Racial Hiring Practices of Employers, 49 J.L. \& ECON. 45 I, 47 I (2006); Devah Pager, The Mark of a Criminal Record, , 08 AM. J. SOC. 937, 960 (2003).

31 Debbie Mukamal, U.S. DeP'T of Labor, From Hard Time to Full Time: Strategies to Help MOVE Ex-OFfEnders From Welfare to WORK, Part III.B (200I), https://hirenetwork.org/sites/default/files/From\% $20 H$ ard $\% 20$ Time $\% 2$ oto $\% 20 F u l l \% 20$ Time.pdf [https://perma.cc/2XM8-H8KT]; Amy L. SOlomon et AL., Urban Inst., From PRISON to Work: THE EMPloYMent Dimensions OF PRISONER REENTRY 8-II (2004), https://www.urban.org/sites/default/files/publication/58 I 26/4I I097-From-Prison-to-Work.PDF [https://perma.cc/6W2R-CFQS]; JEREMY TRAVIS ET AL., URBAN INST., FROM PRISON TO HOME: 
seems to directly harm employment prospects. ${ }^{32}$ Many employers report that they take steps to avoid hiring individuals with records. ${ }^{33}$ Their motivations for doing so vary. A report prepared for the Department of Labor has found that many employers are driven by "bias and stigma."34 Some believe that individuals with records cannot be trusted. ${ }^{35}$ Others fear a negligent-hiring lawsuit if an employee hired with a criminal record commits a crime while on the job. ${ }^{36}$

Experimental results confirm employers' reluctance to hire individuals with records. Devah Pager had matched pairs of testers, differing only in criminal history, apply for a range of employment positions. ${ }^{37}$ She found that applicants without records received more than twice as many callbacks. ${ }^{38}$ More recently, Amanda Agan and Sonja Starr sent around $\mathrm{I}_{5}, 000$ fictitious job applications paired by race to entry-level jobs mainly in the restaurant and retail industries. ${ }^{39}$ They found that

The Dimensions and Consequences of PRisoner Reentry 3I-33 (200I), http://research.urban.org/UploadedPDF/from_prison_to_home.pdf [https://perma.cc/K2Z6-RYGR].

32 Cherrie Bucknor \& Alan Barber, Ctr. For Econ. \& Policy Research, The PRICE WE PAY: ECONOMIC COSTS OF BARRIERS TO EMPLOYMENT FOR FORMER Prisoners AND PEOPle ConviCTED OF Felonies IO-I3 (20I6), http://cepr.net/images/ stories/reports/employment-prisoners-felonies-2016-06.pdf? $\mathrm{v}=5 \quad$ [https://perma.cc/M $\left.\mathrm{M}_{5} 8 \mathrm{~K}-\mathrm{E}_{5} \mathrm{FE}\right]$; Scott H. Decker et Al., Criminal Stigma, Race, Gender, And Employment: AN EXPANDED ASSESSMENT OF THE CONSEQUENCES OF IMPRISONMENT FOR EMPLOYMENT 56 (20I4), https://www.ncjrs.gov/pdffilesi/nij/grants/244756.pdf [https://perma.cc/M82 H-3 DHQ]. In a small study of expungement seekers in Chicago, "participants reported attempts to use face-toface contact with potential employers and landlords to convince them that, despite their criminal records, they were trustworthy and dependable. However, participants with both extensive and minor criminal record histories indicated that these attempts were ineffective." Simone Ispa-Landa \& Charles E. Loeffler, Indefinite Punishment and the Criminal Record: Stigma Reports Among Expungement-Seekers in Illinois, 54 CRIMINOLOGY 387, 40I (20I6) (internal citations omitted).

33 Michelle Natividad Rodriguez \& Maurice Emsellem, Nat'L Emp'T LaW Project, 65 Million "Need Not Apply": The CASe for Reforming Criminal BACKGROUND CHECKS FOR EMPLOYMENT I (20II), https://www.nelp.org/wp-content/ uploads/2015/03/65_Million_Need_Not_Apply.pdf [https://perma.cc/8YS6-F 2 SR]; Holzer et al., supra note 30, at 455; Sarah Esther Lageson et al., Legal Ambiguity in Managerial Assessments of Criminal Records, 40 LAW \& SOC. INQUIRY I75, I9I (20I5).

34 MukAMal, supra note 3I, at III.B.

35 See Harry J. Holzer, Collateral Costs: Effects of Incarceration on Employment and Earnings Among Young Workers, in Do PRIsOns MAKe Us SAFER? The Benefits And Costs OF The PRISON BOOM 239, 248 (Steven Raphael \& Michael A. Stoll eds., 2009).

36 LOVE ET AL., supra note 6, §§ 6:I 8-6:29; see also MUKAMAL, supra note 3I, at IV.A.2; SoC'Y FOR HuMAN RES. MGMT. \& CHARLES KOCH INST., WORKERS WITH CRIMINAL RECORDS 5 (20I8), https://www.shrm.org/hr-today/trends-and-forecasting/research-and-surveys/pages/secondchances.aspx [https://perma.cc/JDQ8-T9ME]; Holzer, supra note 35, at 243.

37 Pager, supra note 30 , at $946-48$.

38 See id. at 958 fig.6.

39 Amanda Agan \& Sonja Starr, Ban the Box, Criminal Records, and Racial Discrimination: A Field Experiment, I33 Q.J. ECON. I9I, I92, I98 (2018) [hereinafter Agan \& Starr, Ban the Box]; Amanda Agan \& Sonja Starr, The Effect of Criminal Records on Access to Employment, Iо7 AM. ECON. REV. 560, 560-6I (2017). 
when employers asked about criminal history, the applicants without records received $63 \%$ more callbacks, even though the records in question were relatively minor. ${ }^{40}$ Many employers, influenced by the national "Ban the Box" movement and resulting law changes, have removed questions about criminal history from initial job applications - but these employers typically still conduct background checks before finalizing a hire. ${ }^{41}$ A survey in $20 \mathrm{I} 2$ reported that $87 \%$ of randomly sampled employers performed criminal background checks on at least some employees; $69 \%$ performed background checks on all employees. ${ }^{42}$ This represented an expansion from an earlier era, driven by the availability of easier and less costly internet-based searches. ${ }^{43}$ Almost all states place court records on the internet, ${ }^{44}$ and private companies, such as Westlaw and LexisNexis, also market criminal history databases. ${ }^{45}$

In addition to these employment consequences, criminal convictions bring with them a wide range of other "collateral" legal consequences that is, consequences that are not part of the sentence but a function of a wide array of civil laws. Licensing restrictions categorically exclude previously convicted individuals from hundreds of professions. ${ }^{46}$ These individuals are often prohibited from receiving various social services, including welfare and health benefits, public housing, and food

40 Agan \& Starr, Ban the Box, supra note 39, at 195, 200.

41 See id. at I93 n.3. The slogan refers to the fact that such questions are often set apart in a box on the application form.

42 See Soc'y for Human Res. Mgmt., SHRM Survey Findings: Background Checking - The Use of Criminal BACKGRound CHECKS IN HiRING DECISIONS (20I2), https://www.shrm.org/hr-today/trends-and-forecasting/research-and-surveys/Pages/ criminalbackgroundcheck.aspx [https://perma.cc/3EQU-KBQL].

43 See JACOBS, supra note 7, at 5; LOVE ET AL., supra note 6, § 5:2; Jeffrey Selbin et al., Unmarked? Criminal Record Clearing and Employment Outcomes, I08 J. CRIM. L. \& CRIMINOLOGY I, 9 (20I8).

44 See Privacy/Public Access to Court Records: State Links, NAT'L CTR. FOR ST. CTS., https://www.ncsc.org/topics/access-and-fairness/privacy-public-access-to-court-records/state-links [https://perma.cc/V2 $\mathrm{HP}-3 \mathrm{~J} 6 \mathrm{M}]$.

45 See Ben Geiger, Comment, The Case for Treating Ex-offenders as a Suspect Class, 94 CALIF. L. REV. II9I, II98-99 (2006).

46 See Chidi Umez \& Rebecca Pirius, Nat'L Conference of State Legislatures, BARRIERS TO WORK: IMPROVING EMPLOYMENT IN LICENSED OCCUPATIONS FOR INDIVIDUALS WITH CRIMINAL RECORDS 3 (20I8), http://www.ncsl.org/Portals/r/Documents/ Labor/Licensing/criminalRecords_vo6_web.pdf [https://perma.cc/6GKS-GJUF]; Alec C. Ewald, Collateral Consequences and the Perils of Categorical Ambiguity, in LAW AS PUNISHMENT/LAW as Regulation 77, 87-88 (Austin Sarat et al. eds., 20I I); Policy Changes Needed to Unlock Employment and Entrepreneurial Opportunity for Ioo Million Americans with Criminal Records, Kauffman Research Shows, BUSINESSWIRE (Nov. 29, 20I6, 8:00 AM), https://www.businesswire.com/ news/home/20I6 I I 2 9005528/en/Policy-Needed-Unlock-Employment-Entrepreneurial-OpportunityIo० [https://perma.cc/UA6K-VEEG]; Shoshana Weissmann \& Nila Bala, Opinion, Criminal Justice, Occupational Licensing Reforms Can Go Hand in Hand, The Hill (Apr. 15, 2018, 4:30 PM), https://thehill.com/opinion/civil-rights/383262-criminal-justice-occupational-licensing-reforms-cango-hand-in-hand [https://perma.cc/R7 ${ }_{7} \mathrm{SU}-\mathrm{ZMWZ}$ ]. 
stamps. ${ }^{47}$ Whole families can be evicted from public housing on the basis of one member's convictions. ${ }^{48}$ Exclusion from housing renders individuals with records homeless at high rates - for instance, in I997, the California Department of Corrections estimated that Io\% of its parolees were homeless. ${ }^{49}$ The specifics of these exclusions vary from state to state, although some are encouraged or required by federal law. ${ }^{50}$ They also vary based on crime type. ${ }^{51}$

Because so many Americans have conviction records, these consequences have a large aggregate impact. Repercussions include spillover effects on family members never convicted of any crime; the Center for American Progress estimates that almost half of U.S. children have a parent with some form of criminal record (including arrests). ${ }^{52}$ In addition, because criminal records are not equally distributed across the population, ${ }^{53}$ the effects of these collateral consequences are disproportionately concentrated by race, gender, and poverty status, especially affecting black men. ${ }^{54}$ This concentration of criminal records may therefore be a significant contributor to racial disparities in employment and other socioeconomic outcomes.

47 See StANDARDS FOR CRIMINAL Justice ch. I9, introductory cmt. (AM. BAR ASs'N $3 d$ ed. 2004); Paul Samuels \& Debbie Mukamal, Legal action Ctr., After Prison: ROADBLOCKS TO REENTRY I 2-I3, I6 (2004), http://www.november.org/resources/LACReportCard. pdf [https://perma.cc/FGV5-39ZZ]; Jeremy Travis, Invisible Punishment: An Instrument of Social Exclusion, in Invisible Punishment: The Collateral Consequences of Mass IMPRISONMENT I5, 23-25 (Marc Mauer \& Meda Chesney-Lind eds., 2002); Geiger, supra note 45, at I204-06.

48 Jenny Roberts, Why Misdemeanors Matter: Defining Effective Advocacy in the Lower Criminal Courts, 45 U.C. DAVIS L. REV. 277, 299 (20II).

49 Cal. State Dep't of Corr., Preventing Parolee Failure Program: AN EvAlUATION 2 (I997), https://www.ncjrs.gov/pdffiles I/Digitization/180542NCJRS.pdf [https://perma.cc/JX 2 E- $\left.\mathrm{V}_{3} \mathrm{BZ}\right]$.

50 See Mukamal, supra note 3I, at III.A.I; Gwen Rubinstein \& Debbie Mukamal, Welfare and Housing - Denial of Benefits to Drug Offenders, in Invisible PUNISHMENT, supra note 47, at $37,4 \mathrm{I}-42$; Geiger, supra note 45 , at I 204.

51 See Samuels \& MuKamal, supra note 47 , at i6.

52 Rebecca Vallas et al., Removing Barriers to Opportunity for Parents with Criminal Records and Their Children, CTR. FOR AM. Progress (Dec. IO, 2015, I2:0I AM), https://www. americanprogress.org/issues/poverty/reports/20 I5/I 2/IO/I 26902/removing-barriers-to-opportunityfor-parents-with-criminal-records-and-their-children [https://perma.cc/KUgB-YUH 7 ].

53 See E. Ann Carson, U.S. Dep't OF Justice, Prisoners IN 20i6, at io (2018), https://www.bjs.gov/content/pub/pdf/pi6.pdf [https://perma.cc/68J8-QFQT] (showing imprisonment rates in 2016 at 1609,857 , and 274 per 100,000 U.S. residents for black, Hispanic, and white adults, respectively); Robert Brame et al., Demographic Patterns of Cumulative Arrest Prevalence by Ages I8 and 23, 60 CRIME \& DELINQ. 47 I, 476 (20I4) (finding about half of black men have been arrested by age twenty-three compared to $38 \%$ of white men).

54 See Pew Charitable Trs., supra note 29, at 27; Andi Mullin, Banning the Box in Minnesota - and Across the United States!, Community Catalyst (Dec. 2, 2013), https://www.communitycatalyst.org/blog/banning-the-box-in-minnesota-and-across-the-unitedstates [https://perma.cc/69C6-TBU2]. 


\section{B. Sealing of Criminal Records: The Legal and Policy Landscape}

More than two-thirds of states have adopted statutes that permit adult criminal convictions to be sealed, set aside, or expunged. ${ }^{55}$ These laws generally require state agencies to ignore the affected individual's criminal record for most purposes other than law enforcement, thereby lifting any statutory barriers to public employment, licensing, and benefits. The laws also give an individual expungement recipient the legal right to respond "no" when an employer or landlord asks if the applicant has a criminal record. ${ }^{56}$ In most states (including Michigan), sealed convictions remain available for law enforcement purposes, and for sentencing in the event of a subsequent crime. ${ }^{57}$

The specific eligibility requirements for criminal record expungement vary widely across jurisdictions. For example, some states' laws exclude certain classes of crimes, such as violent felonies. ${ }^{58}$ Waiting periods also vary: In some states, at least for some categories of crime, individuals can apply for expungement immediately after completing their sentence (although evidence of rehabilitation must generally be shown, which can be harder if little time has passed). ${ }^{59}$ Other states, by contrast, have minimum waiting periods ranging from one to twenty years. ${ }^{60}$ In some states (including Michigan), it is illegal for an employer to discriminate on the basis of an expunged conviction if the employer becomes aware of it. ${ }^{61}$ The Collateral Consequences Resource Center and the Clean Slate Clearinghouse provide comprehensive state-by-state information on expungement laws. ${ }^{62}$

Beyond adult conviction records, most states have other expungement policies covering at least some other types of criminal records, such

55 See supra note I I and accompanying text; see also Ispa-Landa \& Loeffler, supra note 32, at 392.

56 Adult Criminal Record FAQs, PAPILLON FOUND., http://www.papillonfoundation.org/ information/expungement-faqs\#Adult_Criminal_Record [https://perma.cc/SA3T-GWF6].

57 See, e.g., Mich. COURTS, NONPUBlic AND Limited-ACCESS COURT ReCORDS (2020), https://courts.michigan.gov/administration/scao/resources/documents/standards/cf_chart.pdf [https:// perma.cc/9SVE-MJR 5 ] (cataloging different kinds of court records and the access restrictions imposed on those records "by statute, court order, or court rule," $i d$. at i, as of January 2020).

58 E.g., N.C. GEN. STAT. § I 5A-I 45.5 (2019); OKLA. STAT. tit. 22 , § I8(A)(I I) (2020).

59 See, e.g., ARiz. Rev. Stat. AnN. § I3-907 (2020); CAL. Penal Code $\S$ i 203.4, I 203.4a (West 2020).

60 See CCRC State Survey, supra note I I.

61 See, e.g., CAL. LAB. CODE $\$ 432.7$ (a)(I) (West 2020) (prohibiting employment discrimination); see also CAL. GOV'T CODE $\S$ I $295^{2}$ (West 2020) (prohibiting disclosure in its new enactment). In Michigan, to use or divulge information about an expunged conviction is a misdemeanor. MICH. COMP. LAWS ANN. $\$ 780.623(5)$ (West 2020) ("Except as provided in subsection (2), a person, other than the applicant..., who knows or should have known that a conviction was set aside under this section and who divulges, uses, or publishes information concerning a conviction set aside under this section is guilty of a misdemeanor punishable by imprisonment for not more than 90 days or a fine of not more than $\$ 500.00$, or both.”).

62 See sources cited supra note II. 
as juvenile records, nonconviction records, or convictions that have been overturned or are subject to successful collateral attack. ${ }^{63}$ Many also have deferred-adjudication programs available for certain defendants (for example, first-time drug crime defendants or youthful defendants), in which no conviction is ever entered if the defendant completes certain requirements. ${ }^{64}$ These laws raise related empirical and policy questions, and discussions about them might well be able to draw on our findings. But we focus here on state laws that expunge otherwise-valid adult convictions that have become final; these policies have been expanding in scope in recent years and are the subject of active political debates in many states. Although supported by the American Bar Association, ${ }^{65}$ and by advocacy groups such as the National Employment Law Project, the Center for American Progress, and Community Legal Services, ${ }^{66}$ they have also met with considerable political opposition, principally from employers, who want access to information that they consider relevant to hiring decisions. ${ }^{67}$

The most recent wave of efforts to expand and improve expungement laws - often referred to by advocates as the "Clean Slate" movement has focused to a large degree on the potential for automatic expungement of certain criminal records after a certain period of time. ${ }^{68}$ The groundbreaking success in this area was the adoption of Pennsylvania's Clean Slate Act, which extends court-ordered criminal record sealing to encompass a broader set of offenses and creates an automatic computerized process for sealing certain eligible convictions: minor nonviolent misdemeanors after ten years without a subsequent conviction. ${ }^{69}$ The Clean Slate

63 See id.

64 See id. (describing deferred-adjudication programs).

65 See Standards for Criminal Justice $§$ i 9-2.5 (Am. Bar Ass'N 3d ed. 2004); Am. Bar Ass'N, Report to the House of Delegates, Resolution iogB, at i (2019), https://www.americanbar.org/content/dam/aba/administrative/house_of_delegates/resolutions/ 20I9-midyear/20I9-midyear-Iogb.pdf [https://perma.cc/SJ5R-2ZV8].

66 See Press Release, Ctr. for Am. Progress, Removing Barriers to Economic Opportunity for Americans with Criminal Records Is Focus of New Multistate Initiative by CAP, NELP, and CLS (Sept. I 2, 20I 7), https://www.americanprogress.org/press/release/20I $7 / 09 / \mathrm{r} 2 / 437592 /$ release-removingbarriers-economic-opportunity-americans-criminal-records-focus-new-multistate-initiative-cap-nelpcls [https://perma.cc/E $73 \mathrm{~W}-\mathrm{W} 8 \mathrm{BK}$ ].

67 See, e.g., Alison Knezevich, New State Laws to Help Marylanders Clear Arrest Records, BALT. SUN (Sept. 26, 2015, гा:02 PM), https://www.baltimoresun.com/maryland/bs-md-expungementchanges-20150926-story.html [https://perma.cc/R $3 \mathrm{X}_{3-4} \mathrm{YFD}$ ]; Nancy Reardon, Activists Want Law to Seal Criminal Records Sooner, PATRIOT LedGer (July 28, 2009, 9:I I PM), https://www. patriotledger.com/x836550449/Activists-want-law-to-seal-criminal-records-sooner [https://perma.cc/B5 R6-W 3 MN].

68 See ClEAN SLATE, https://cleanslateinitiative.org [https://perma.cc/S3FF-JPGA].

69 See Act of June 28, 2018, No. 402, 2018 Pa. Laws No. 56; Press Release, Governor Tom Wolf of Pa., Governor Wolf: "My Clean Slate" Program Introduced to Help Navigate New Law (Jan. 2, 20I9), https://www.governor.pa.gov/governor-wolf-my-clean-slate-program-introduced-to-helpnavigate-new-law [https://perma.cc/ENF 7 -UDRE]; Frequently Asked Questions About Clean Slate, 
Bill received nearly unanimous legislative endorsement and was supported by an overwhelming majority of Pennsylvania residents. ${ }^{70}$

Pennsylvania's club became larger in 2019, when Utah, New Jersey, and California enacted automatic expungement laws, ${ }^{71}$ and similar reform efforts are now underway in several other states, ${ }^{72}$ including Michigan. ${ }^{73}$ These newer laws have all been broader than Pennsylvania's pioneering statute along some dimensions. Of these laws, California's is the most ambitious, although (unlike the others) it does not apply retrospectively. ${ }^{74}$ The California law applies to all misdemeanors and to some felonies resulting in probation, ${ }^{75}$ and it imposes no lengthy waiting period - indeed, none beyond sentence completion in some cases. ${ }^{76}$ Utah's law, like Pennsylvania's, is limited to nonviolent misdemeanors, but its waiting periods for most crimes are only five to seven years depending

Community Legal Servs. Phila. (June 26, 20I8), https://clsphila.org/learn-about-issues/ frequently-asked-questions-about-clean-slate [https://perma.cc/3 $\mathrm{PY}_{5}-\mathrm{U}_{3} \mathrm{CM}$ ].

70 See J.D. Prose, Pennsylvania Becomes First State with "Clean Slate" Law for Nonviolent Criminal Records, THE TIMES (June 28, 2018, 5:00 PM), https://www.timesonline.com/ news/20180628/pennsylvania-becomes-first-state-with-clean-slate-law-for-nonviolent-criminal-records [https://perma.cc/2 EVM-B 5 RE].

71 See Cal. Penal Code $§$ I 203.425(a)(2)(E) (West 2020); N.J. Stat. ANN. § 2C:52-5.4 (West 2020); UTAH CODE ANN. § 77-40-102 (LexisNexis 2020).

72 See, e.g., David Brand, A Criminal Justice Reform Would Give Thousands a Clean Slate - If Only They Would Apply, BROOKLYN DAILY EAGLE (Nov. 25, 20I9), https://brooklyneagle.com/ articles/20I $9 /$ I I/25/a-criminal-justice-reform-would-give-thousands-a-clean-slate-if-only-theywould-apply [https://perma.cc/34 $\mathrm{H}_{3}-\mathrm{NDKR}$; Gemma Gaudette, Bipartisan Proposal Would Give Some Former Idaho Inmates a "Clean Slate," BOISE ST. PUB. RAdiO (Jan. 29, 2020), https://www.boisestatepublicradio.org/post/bipartisan-proposal-would-give-some-former-idahoinmates-clean-slate\#stream/o [https://perma.cc/L6E $3-8 \mathrm{WXZ}$ ]; Asti Jackson \& Phil Kent, A Criminal Record Should Not Be a Lifetime Sentence; That's Why We Need the Clean Slate Law, HARTFORD COURANT (Mar. I5, 2020, 6:00 AM), https://www.courant.com/opinion/op-ed/hc-op-jackson-kentclean-slate-0315-20200315-7bohb5 by5nfmpkrbh6fngml 4fy-story.html [https://perma.cc/9WZY$\left.\mathrm{Z}_{3} \mathrm{GH}\right]$. There is also activity at the federal level. Nila Bala \& Rebecca Vallas, Opinion, State Momentum in Criminal Record Sealing Fuels Federal Clean Slate Bill, THE HILl (Mar. 2, 2020, 2:00 PM), https://thehill.com/opinion/criminal-justice/485477-state-momentum-in-criminal-recordsealing-fuels-federal-clean-slate-bill [https://perma.cc/W $5 \mathrm{MN}^{\mathrm{M}} \mathrm{T}_{2} \mathrm{~GB}$ ]; Press Release, Ctr. for Am. Progress, supra note 66.

73 See, e.g., Riley Beggin, Michigan Eyes Reform to Costly, Confusing System of Expunging Criminal Records, BRIDGE MAG. (Nov. 4, 20I9), https://www.bridgemi.com/michigan-government/ michigan-eyes-reform-costly-confusing-system-expunging-criminal-records [https://perma.cc/4D83CZXU]; Miriam Francisco, New Bill Would Automate Process of Criminal Record Expungement for Certain Convictions, Detroit Metro Times (Sept. 20, 20I9, 3:24 PM), https://www.metrotimes.com/news-hits/archives/201 $9 / 09 / 20 /$ new-bill-would-automate-process-of-criminal-recordexpungement-for-certain-convictions [https://perma.cc/AC 4 M-DTGF].

74 CAL. Penal CODE $\S$ I 203.425 (a)(2)(E) (noting that the automatic conviction relief only applies to "conviction[s] [that] occurred on or after January I, $202 \mathrm{I}$ ").

75 Id.

$76 I d$. (indicating that otherwise-qualifying individuals who receive probation become eligible for such relief immediately after successfully completing probation while those with misdemeanor or infraction convictions become eligible immediately after completing their sentence, so long as a year has elapsed since the conviction's date of judgment). 
on the crime class. ${ }^{77}$ New Jersey's automatic expungement law has a ten-year waiting period, but it allows some more serious crimes to be automatically expunged; it delegates to a task force the development of the process. ${ }^{78}$ In addition, proposed federal legislation would require automatic expungement one year after completing a sentence for marijuana offenses and certain other minor drug offenses. ${ }^{79}$

Many states and local jurisdictions have also adopted other laws designed to reduce barriers to employment of people with criminal records. The most important category (along with expungement laws) are Banthe-Box laws and policies, which typically bar employers from asking about records on initial job application forms and in initial interviews. ${ }^{80}$ Thirty-five states (and the District of Columbia) and over I50 cities and counties have passed Ban-the-Box laws governing public employers, and a further thirteen states and eighteen cities and counties now extend them to private employers. ${ }^{81}$ In terms of the number of people affected, Ban-the-Box laws are far more sweeping than typical expungement laws because they apply to all criminal records and contain no eligibility requirements. However, expungement, for those who do obtain it, offers potentially far more significant relief from the consequences of criminal convictions, cutting across different domains of life and, in effect, legally erasing the conviction in question. In contrast, Ban-the-Box laws primarily affect employer practices, and only change the timing of employers' receipt of record-related information; they can still refuse to hire an applicant after completing a background check. ${ }^{82}$ Still, Clean Slate advocates typically see the two types of reforms as complementary, and many advocacy organizations have pushed for both. ${ }^{83}$

Some states have also adopted laws that substantially restrict employers' use of criminal record information — for example, requiring that they

77 UTAH CODE ANN. § 77-40-105(2-3) (LexisNexis 2020).

78 N.J. STAT. ANN. \& 2 C:52-5.4 (West 2020).

79 Clean Slate Act of 2019, H.R. 2348, i 16 th Cong.

80 See linda Evans, All of Us or None, Ban the Box in Employment: A GRASSROOTS HISTORY 8 (20I6), http://www.prisonerswithchildren.org/wp-content/uploads/ 20I6/Io/BTB-Employment-History-Report-20I6.pdf [https://perma.cc/6P9Z-AP 38 ]. The Ban-theBox campaign was initiated in 2004 by All of Us or None, a national civil rights movement, to eliminate the box on employment forms (as well as other applications) that asks whether an applicant has ever been convicted of a felony. See $i d$. at ro.

81 Beth Avery, NAT'L EmP'T LAW Project, Ban the Box I (20I9), https://s2 7 I 47 .pcdn.co/wp-content/uploads/Ban-the-Box-Fair-Chance-State-and-Local-GuideJuly-20I9.pdf [https://perma.cc/33QT-FEZK].

82 See Agan \& Starr, Ban the Box, supra note 39, at 193.

83 See, e.g., Angela Hanks, Ban the Box and Beyond, CTr. FOR Am. Progress (July 27, 20I 7 , 9:03 AM), https://www.americanprogress.org/issues/economy/reports/201 $7 / 07 / 27 / 436756 /$ ban-boxbeyond [https://perma.cc/5 $\left.\mathrm{T}_{7} \mathrm{~V}-58 \mathrm{NU}\right]$. 
only rely on information that is job relevant. ${ }^{84}$ These laws essentially replicate guidance long given by the federal Equal Employment Opportunity Commission (EEOC), which holds that overly sweeping bans on employees with records can amount to disparate impact racial or national origin discrimination. ${ }^{85}$ Unfortunately, courts have been reluctant to enforce these restrictions. ${ }^{86}$ Many employers throughout the country continue to implement blanket exclusions of individuals with records, notwithstanding EEOC's guidance ${ }^{87}$ - which, in any event, the Fifth Circuit recently ruled is not enforceable. ${ }^{88}$ These practices, and the difficulty of eliminating them through other legal mechanisms, are among the motivations for expungement laws.

\section{Research Questions and Existing Empirical Research on Expungement}

There has been very little empirical research on any of the many questions surrounding expungement laws, despite the clear importance of these inquiries to policymakers and the lives of millions of Americans. In truth, most of these questions really cannot be answered effectively

84 See AVERY, supra note 8I, at I-2.

85 See U.S. EQUAL EMP'T OPPORTUNiTy COMM'N, No. 9I5.002, ENFORCEMENT GuIDANCE: CONSIDERATION OF ARREST AND CONVICTION RECORDS IN EMPLOYMENT DECisions UNDER Title VII OF THE Civil Rights ACT OF I964 (20I2), https://www.eeoc.gov/laws/guidance/arrest_conviction.cfm [https://perma.cc/UK 3 G-DAAH].

86 See Dallan F. Flake, When Any Sentence Is a Life Sentence: Employment Discrimination Against Ex-offenders, 93 WASH. U. L. REV. 45, 80 (2015) ("[T]he EEOC has yet to prevail in court ...."); see also Benjamin Levin, Criminal Employment Law, 39 CARDOzO L. REV. 2265, 2303 (2018); Geiger, supra note 45, at I 203 (indicating that at least early versions of state laws were "severely underutilized"); $i d$. at I I 99 ("[R]egulations [may be] especially difficult to enforce since, in order for an applicant to know that a rejection was based on the use of prohibited criminal history information, either the applicant would have to sue and obtain subpoena power to see the job application information or the employer would have to freely admit the illegal basis for rejecting the applicant.").

87 See Rodriguez \& EMSEllem, supra note 33, at 3; U.S. COMM'N ON Civil Rights, Collateral Consequences: The Crossroads of Punishment, Redemption, And THE EFFECTS ON COMMUNITIES I 34 (20I9), https://www.usccr.gov/pubs/20I9/o6-I3-CollateralConsequences.pdf [https://perma.cc/WX86-2BMM] ("Employment is difficult to access for those individuals with a criminal conviction as many employers choose to use a blanket ban on hiring any person with a prior criminal conviction regardless of the offense committed by the person."); Miriam J. Aukerman, The Somewhat Suspect Class: Towards a Constitutional Framework for Evaluating Occupational Restrictions Affecting People with Criminal Records, 7 J.L. \& SoC'Y I8, 26 (2005); Mark Jones et al., Challenges Facing Released Prisoners and People with Criminal Records: A Focus Group Approach, 2 Corrections: POL'Y PRAC. \& RES. 9i, 97-98 (20I7); see also MUKAMAL, supra note $3 \mathrm{I}$, at III.B.

88 See Texas v. EEOC, 933 F.3d 433, 45 I (5th Cir. 20I9); CCRC Staff, Appeals Court Invalidates EEOC Criminal Record Guidance, COLlATERAL CONSEQUENCES RESOURCE CTR. (Aug. 7, 20I9), http://ccresourcecenter.org/20I9/08/o7/appeals-court-invalidates-eeoc-criminal-record-guidance [https://perma.cc/9PT6-245J]; Alonzo Martinez, Fifth Circuit to EEOC - Don't Mess with Texas, FORBES (Aug. I3, 20I9, 4:57 PM), https://www.forbes.com/sites/alonzomartinez/20I9//I3/fifth-circuitto-eeoc-dont-mess-with-texas/\#4е I 7c8f6c897 [https://perma.cc/5 GMY-Z9Y7]. 
absent comprehensive access to individual-level data on people whose records have been expunged, and because those records are generally unavailable, research has been stymied. Fortunately, by taking advantage of our unusual data access, we are able to examine several key questions that have long remained unanswered.

First, there is essentially no research on the question of "uptake" in the context of the expungement of convictions. The basic question relates to the uptake rate: When people are legally eligible for expungement, how often do they actually apply for and receive it? Beyond this question, we also seek to provide a richer picture of who receives relief - what kinds of convictions they have, what types of sentences they served, their demographics - and how their profiles compare to those of the broader pool of eligible persons, that is, what factors predict actual receipt. Answering these questions can help us better understand the problem of "uptake gaps" and can also inform the discussion of expungement's effects. Given that the group that actually receives relief is a highly selected one, in order to speculate as to the potential results of extending expungement laws to a broader and possibly dissimilar population, we need to understand that selection process.

Again, no published study addresses these questions with respect to expungement laws. ${ }^{89}$ However, in certain other post-conviction relief contexts, there have been a few attempts to explore issues related to uptake. The most comprehensive such effort is Colleen Chien's research estimating the uptake rates for several programs: President Obama's clemency initiative allowing certain federal inmates to apply for sentence commutation; California's Proposition 47, which allows some felony convictions to be reduced to misdemeanors; and California's Proposition 64, which legalized marijuana and provides various forms of relief for those previously convicted on marijuana charges. ${ }^{90}$ She finds uptake rates of about $3 \%, 9 \%$, and $3 \%$, respectively (within a relatively short time period, especially for the newer Proposition 64). ${ }^{91}$ Chien also analyzes a sample of background-check data concerning

89 Very recently, Colleen Chien et al. released a short summary of preliminary findings from their study of expungement uptake in Washington State. Colleen V. Chien et al., The Washington State Second Chance Expungement Gap I (Feb. 28, 2020) (unpublished manuscript), https:// papers.ssrn.com/sol $3 /$ papers.cfm?abstract_id $=3529777$ [https://perma.cc/7AX6-PBE7]. The study uses a random sample of cases to estimate how many cases are eligible for expungement in Washington; comparison to reported statistics on the total number of expungements actually granted implies that only about $3 \%$ of eligible individuals obtain expungement. See id. at 2,5 .

90 Colleen V. Chien, The Second Chance Gap, I I 9 MICH. L. REV. I 2 (forthcoming 2020) (manuscript at I 2), https://papers.ssrn.com/sol $3 /$ papers.cfm?abstract_id=3265335 [https://perma.cc/R8SH-HY 5 T].

91 Id. (manuscript at $\mathrm{I} 7-23$ ). The study does not use individual-level data to identify eligible cases and track their outcomes. Instead, it compares publicly reported figures on the estimated numbers of people eligible for relief and on the number of applications. See id. 
"gig" jobseekers and finds evidence that many reports contain nonconviction records (for example, arrests not leading to convictions), at least some of which should be clearable under state law. ${ }^{92}$ Research by Christopher Uggen and coauthors also uncovers large uptake gaps in voting rights-restoration procedures for people disenfranchised due to felony convictions..$^{93}$ Although none of these estimates focuses on the expungement of criminal convictions, they all suggest a general problem: when criminal justice relief mechanisms require individuals to go through application procedures, many people who might benefit from them will not do so.

Second, we investigate subsequent recidivism outcomes for expungement recipients. We explore this particular outcome in order to address the concern, often raised by opponents of record-sealing, that the public has a safety interest in being able to identify people with records. ${ }^{94}$ We are unaware of any other empirical research on this question - a question we are able to investigate because we have recipients' full criminal records, including post-expungement convictions. ${ }^{95}$ Evidence on the recidivism question is critical to addressing objections from those who fear endorsing expungement policies because of the possibility that these policies could hide or increase recidivism risk.

Third, we examine the employment consequences of expungement. Although potential employment benefits are core to the policy case for

92 See id. (manuscript at 25-35). The rates at which such nonconviction records appeared varied substantially by state. See $i d$. at 32 n. I30. Note that because cleared records do not appear in background check data, Chien's approach does not identify the number or share of eligible people who do clear nonconviction records; rather, it simply shows that there are many who have not done so. To estimate uptake rates for expungement among those eligible requires access to cleared records, which researchers typically have not had. For background on nonconviction criminal records, their use, and their regulation, see generally Collateral CONSEQUENCES Res. CTR., MODEL LAW ON NON-CONVICTION RECORDS at v-vii (2OI9), http://ccresourcecenter.org/model-law-on-non-conviction-records-3 [https://perma.cc/PY $5 \mathrm{~W}-\mathrm{BYSY}]$.

93 Christopher Uggen et Al., Sentencing Project, 6 Million lost Voters: StATE-LEVEl Estimates OF FELONy DisenfRANCHISEMENT, 20i6, at i3 (20I6), https://www.sentencingproject.org/wp-content/uploads/2016/ıo/6-Million-Lost-Voters.pdf [https://perma.cc/E9GB-Y 2 NG].

94 See T. Markus Funk, The Dangers of Hiding Criminal Pasts, 66 TENN. L. REV. 287, 298-99 (I 998); Margaret Colgate Love, Starting Over with a Clean Slate: In Praise of a Forgotten Section of the Model Penal Code, 30 Fordham URB. L.J. I705, I726 (2003); Michael D. Mayfield, Comment, Revisiting Expungement: Concealing Information in the Information Age, I997 UTAH L. REV. 1057, 1065-66, 1069-70.

95 Some theoretical and qualitative work has explored a few potential mechanisms by which expungement policies could reduce recidivism. See, e.g., Ericka B. Adams et al., Erasing the Mark of a Criminal Past: Ex-offenders' Expectations and Experiences with Record Clearance, I9 PUNISHMENT \& SOC'Y 23, 45-47 (20I7) (finding, based on interviews with forty people, that expungement encourages attitudinal shifts that could potentially be associated with reduced recidivism); Murat C. Mungan, Reducing Crime Through Expungements, I37 J. ECON. BEHAV. \& ORG. 398, 399 (2017) (arguing that offering expungements but making them costly could allow governments to "separate generally-law-abiding-citizens" from career criminals, thereby reducing crime). 
expungement laws, they have proven especially difficult to study because both expunged criminal records and wage and employment records are typically confidential. The above-cited research showing that criminal records impair employment opportunities provides a strong intuitive reason to believe that expunging those records should have the opposite effect. However, for several reasons, this intuition could prove to be incorrect, and the magnitude of any effect is unknown. First, many commentators have expressed concern that expungement may fail to hide criminal history information from inquisitive employers - for example, if news stories, mug shots, or other information about past offenses can be easily found with a Google search or other digital means, ${ }^{96}$ or if private criminal records databases do not effectively delete expunged records. ${ }^{97}$ Second, the waiting periods built into expungement laws may undermine any potential benefits because these restrictions mean that expungement cannot help during the critical period immediately after a conviction or during reentry. ${ }^{98}$ Third, people with records often also tend to face many other employment disadvantages besides the record itself, potentially limiting the benefits of expungement. ${ }^{99}$

To date, the most on-point research is a recent study by Jeffrey Selbin, Justin McCrary, and Joshua Epstein, which tracks labor market outcomes for 235 clients of a law clinic who pursued either expungement or another form of relief (which allowed the reduction of felonies to misdemeanors). ${ }^{100}$ The authors find suggestive evidence of employment

96 See Victoria Cumbow, Everything Posted Online Is There Forever, Even After It's Been Deleted, AL.COM (last updated Jan. I4, 2019), http://blog.al.com/breaking/201 I/o3/everything _posted_online_is_th.html[https://perma.cc/6MHW-XTL5]; see also Sarah Esther Lageson, There's No Such Thing as Expunging a Criminal Record Anymore, Slate (Jan. 7, 2019, 2:44 PM), https://slate.com/technology/2019/or/criminal-record-expungement-internet-due-process.html [https:// perma.cc/H3EW-J396]; Experts: Deleted Online Information Never Actually Goes Away, CHI. TRIB. (Aug. 2I, 20I5, II:26 AM), https://www.chicagotribune.com/business/blue-sky/chi-deleted-onlineinformation-never-goes-away-20I $5082 \mathrm{I}$-story.html [https://perma.cc/5 A8N-GCBH].

97 See Clay Calvert \& Jerry Bruno, When Cleansing Criminal History Clashes with the First Amendment and Online Journalism: Are Expungement Statutes Irrelevant in the Digital Age?, I9 CommLaW Conspectus I23, I23-24 (2010); Alessandro Corda \& Sarah E. Lageson, Disordered Punishment: Workaround Technologies of Criminal Records Disclosure and the Rise of a New Penal Entrepreneurialism, 60 BRIT. J. CRIMINOLOGY 245, 247, 260-6I (2020); Marc A. Franklin \& Diane Johnsen, Expunging Criminal Records: Concealment and Dishonesty in an Open Society, 9 Hofstra L. Rev. 733, 745-48 (1981); Eldar Haber, Digital Expungement, 77 MD. L. REv. 337, 355-57 (2018); Love, supra note 94, at I7 I9, I725-26; Jenny Roberts, Expunging America's Rap Sheet in the Information Age, 2015 WIS. L. REV. 32 I, 34 I-46; Mayfield, supra note 94, at 1068-69; Sharon M. Dietrich, Ants Under the Refrigerator?, CRIM. JUST., Winter 20I6, at 26, 26, $\mathrm{http}: / /$ ccresourcecenter.org/wp-content/uploads/20I $7 / \mathrm{o}_{3} /$ Ants-under-the-Refrigerator-published.pdf [https://perma.cc/2ZQH-BVBN].

98 See JACOBS, supra note 7, at I3I; Franklin \& Johnsen, supra note 97, at 739; Selbin et al., supra note 43 , at 52 .

99 See sources cited supra note $3 \mathrm{I}$.

100 See Selbin et al., supra note 43, at 33, 38, 40. 
gains. ${ }^{101}$ As they acknowledge, however, their small sample size does not "allow for precise estimation,"102 and the study does not present statistical estimates with standard errors (which permit readers to evaluate the degree of imprecision). In addition, their sample is not necessarily representative of those who obtain expungement, ${ }^{103}$ and their data do not allow them to answer the additional questions we discuss above regarding uptake and recidivism outcomes. So while their study provides a welcome start, its objectives were relatively modest. In contrast, we analyze a large, statewide sample that includes all expungement recipients as well as a large comparison group of individuals eligible for expungement, and we are able to use these data to address a variety of interrelated questions with statistical power.

\section{Our Empirical Setting and Data}

We conduct our research in Michigan. Michigan is a large, demographically diverse state; studying its population, therefore, is likely to yield empirical findings that are broadly generalizable to the rest of the United States. For example, Michigan's I4.I\% poverty rate is roughly comparable with the I3.I\% national poverty rate; 104 its $\$ 56,697$ median household income is also close to the U.S. median household income of \$6r,937. ${ }^{105}$ Michigan has roughly the same percentage of people who identify as African American (I3.8\%) and white (78.3\%) try overall, although it has significantly smaller Hispanic and Asian populations. ${ }^{107}$ Michigan's criminal justice system is also reflective of national trends. Michigan's property crime rates are now slightly lower than the national average, but, for most of the study period, they hewed closely to national crime rates; Michigan's violent crime rates are a bit higher than average. ${ }^{108}$ Similarly, Michigan's state prison population

101 Id. at 50-5 I.

102 Id. at 49.

103 See id. at 45-46, 59 .

104 Compare Michigan, U.S. CEnsus BuREAu, https://data.census.gov/cedsci/profile?q= Michigan [hereinafter Michigan Census Data] [https://perma.cc/XRH2-2853], with United States, U.S. Census BurEaU, https://data.census.gov/cedsci/profile?q=United\%20States [hereinafter National Census Data] [https://perma.cc/89 $\mathrm{M}_{4}-\mathrm{TSZ}_{5}$ ].

105 Compare Michigan Census Data, supra note Io4, with National Census Data, supra note Io4.

106 ACS Demographic and Housing Estimates, U.S. CENSUs BurEaU, https://data.census.gov/cedsci/table?q=percent $\% 20$ african $\% 2$ oamerican $\% 20$ michi-

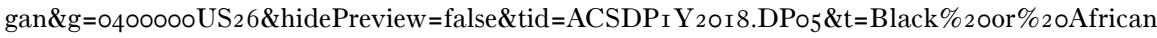
$\% 20$ American\&cid=DPo5_ooorE\&vintage=2018 [https://perma.cc/5487-HNPS].

107 Compare id. (only $5.2 \%$ of the population identifying as Hispanic or Latino in Michigan), and $i d$. (only 3.3\% identifying as Asian), with National Census Data, supra note 104 (18.3\% of the national population identifying as Hispanic or Latino and $5.6 \%$ of the national population identifying as Asian).

108 See Crime Data Explorer: Michigan, Fed. Bureau Investigation, https://crime-dataexplorer.fr.cloud.gov/explorer/state/michigan/crime [https://perma.cc/M8MA-WJUV]. 
increased at roughly the same rate as the overall state prison population in the nation through the mid-2000s. ${ }^{109}$ Today, Michigan's incarceration rate of $64 \mathrm{I}$ per 100,000 people is the 29 th highest in the country, only slightly lower than the national rate of 698 per 100,000. ${ }^{110}$

In Michigan, expungement of criminal convictions is provided for by a longstanding statute, M.C.L. 780.62 I. The law actually labels this process a criminal record "set aside," rather than using the more recognizable term "expungement." And indeed, as in most states, the Michigan process does not entail a complete expungement of the record (which is retained by the police for limited purposes mainly related to criminal justice), but rather a sealing and an elimination of many of the record's legal consequences. However, to maintain consistency with the terminology we adopt elsewhere in this Article, we will continue to use the term "expungement" as a convenient and familiar shorthand.

M.C.L. $780.62 \mathrm{I}$ has been on the books since the I960s, ${ }^{111}$ although expungements were very rare before a significant statutory change that took effect in $1983 .{ }^{112}$ It has undergone some recent amendments, mostly expansions in its eligibility provisions. ${ }^{113}$ Because of the time range of our data, the most relevant version of the law is the one that was in effect (with no material changes) from I 983 until mid-20I I. Our empirical analyses focus on people eligible under that law's requirements, and on expungements granted before the law changed in $20 \mathrm{II}$. The fact that Michigan has had an expungement law for decades distinguishes it from the majority of other states, ${ }^{114}$ and it makes the state a

109 Compare Michigan Profile, PRISON POL'y INITIATIVE, https://www.prisonpolicy.org/ profiles/MI.html [https://perma.cc/TE 7 G-2 AMD], with State Prison Incarceration Rate, I978-20I2, PRISON POL'Y INITIATIVE, https://www.prisonpolicy.org/graphs/US_state_incrates_I978$20 \mathrm{I} 2 . \mathrm{html}\left[\mathrm{https} / / /\right.$ perma.cc/2 $\left.\mathrm{JL}_{3-5} \mathrm{SUM}\right]$ (calculating the rate of increase as the slope of a line fitted to the annual data).

110 Peter Wagner \& Wendy Sawyer, States of Incarceration: The Global Context 20I8, PRISON POL'y INITIATIVE (June 20I8), https://www.prisonpolicy.org/global/20I8.html [https://perma.cc/ U8DU-DABN].

111 Мich. COMP. LAWS $\S 780.62$ I (2019); see also A Brief History of Expungement in Michigan, SAFE \& JUST MiCH. (Aug. 22, 20I8), https://www.safeandjustmi.org/2018/08/2 2/a-brief-history-ofexpungement-in-michigan [https://perma.cc/NP4V-96KR] [hereinafter $A$ Brief History].

112 Only a handful of earlier expungements appear in our comprehensive dataset. For a related discussion, see A Brief History, supra note i I I. Advocating for amendments, one judge wrote in I 98 I that the available procedures at the time were "segmented and confusing." William S. Easton, Commentary, Expunging Criminal Records: A Judge's Perspective, 27 WAYNE L. REv. I39I, I392 (I98I). Prior to the statute's amendment, the limited availability of expungement in Michigan was driven by the difficulties of accessing arrest records, see id. at 1394 , and the narrowness of the procedures available to seek expungement, see People v. Upshaw, 283 N.W.2d 778, 779 (Mich. Ct. App. I979). The statute was amended in I982. See I982 Mich. Pub. Acts I887.

113 See A Brief History, supra note I I I.

114 See generally Love, supra note 94, at $\mathrm{1} 7 \mathrm{I} 7-26$ (surveying the expansion and contraction of expungement laws and policies in the United States); CCRC State Survey, supra note I I. 
particularly useful subject for empirical study; Michigan's long experience with record clearing can inform other states that have recently adopted or are considering adopting similar policies. Cumulatively, tens of thousands of people have received expungements under Michigan's law, and many received them long enough ago to allow us to observe their post-expungement outcomes for a substantial period of time.

Michigan's expungement law imposes a five-year waiting period, ${ }^{115}$ which is in the middle of the range of the waiting periods that other states' statutes apply. ${ }^{116}$ In the pre-20 I i version, the five-year clock began running at sentencing, unless the defendant served a term of incarceration after sentencing, in which case it ran from release. ${ }^{117}$ Any reconviction during this five-year period disqualified the individual from an expungement. ${ }^{118}$ Essentially, then, the law required five "clean" years, excluding time behind bars. The statute covered (and still covers) almost all types of crimes, including most violent felonies. ${ }^{119}$ The principal exceptions are traffic offenses, sex offenses that are subject to registration requirements, and the most serious class of felonies: those carrying potential life-imprisonment terms. ${ }^{120}$ The wide range of crimes otherwise covered is another advantage of Michigan's law for research purposes; it allows us to compare uptake rates and outcomes across many important offense types and grades.

115 Mich. COMP. LAWS § 780.62 I(5) (20I9) ("An application [for expungement] shall only be filed 5 or more years after whichever of the following events occurs last: [listing imposition of sentence, completion of probation, discharge from parole, or completion of a term of imprisonment]."); see also MICH. COMP. LAWS $\S 780.62$ I(3) (20I I) ("An application shall not be filed until at least 5 years following imposition of the sentence for the conviction that the applicant seeks to set aside or 5 years following completion of any term of imprisonment for that conviction, whichever occurs later.").

116 See, e.g., IND. CODE $§ 35-38-9-2$ (c) (20I9) (five-year waiting period); KAN. STAT. ANN. § 2 I66I4 (20I9) (three to five years); LA. CODE CRIM. Proc. ANN. arts. 977(A)(2), 978(A)(2) (20I9) (five-year waiting period for most misdemeanors and ten-year waiting period for felonies); MD. Code Ann., Crim. Proc. § io-iro(c) (West 20ig) (ten to fifteen years); Minn. Stat. $\S 609$ A.02(3)(a)(2)-(5) (20I9) (one to five years, based on offense severity); Mo. REv. STAT. \$6IO.I4O(5)(I) (20I9) (three years for misdemeanors; seven for felonies); NEv. REv. STAT. $\S$ I 79.245(I) (20I9) (effective July I, 2020) (one to ten years, based on offense severity); N.Y. CRIM. ProC. LAW § I60.59(5) (McKinney 20I9) (ten years); see also MARgaret Love, Josh GAines \& JENNy OSBORne, Forgiving AND FORGETting IN AMERICAN Justice: A 50-STATE Guide tO Expungement AND RESTORATION OF Rights 84-II2 (20I8), http:// ccresourcecenter.org/wp-content/uploads/20I $7 /$ Io/Forgiving-Forgetting-CCRC-Aug-2018.pdf

[https://perma.cc/SQ57-YQKN]; CCRC State Survey, supra note I I.

117 Mich. COMP. LAWS $\$ 780.62 \mathrm{I}(3)$ (20II).

118 Id. $\S 780.62 \mathrm{I}(4)(\mathrm{c})$.

119 Id. $\$ 780.62 \mathrm{I}(\mathrm{I})$ (" $[\mathrm{A}]$ person who is convicted of not more than I offense may file an application ....").

120 Id. $\S 780.62 \mathrm{I}(2)$ ("A person shall not apply to have set aside, and a judge shall not set aside, a conviction for a felony for which the maximum punishment is life imprisonment or an attempt to commit a felony for which the maximum punishment is life imprisonment, a conviction for a violation or attempted violation of section $5200,520 d$, or $520 \mathrm{~g}$ of the Michigan penal code, ... or a conviction for a traffic offense."). 
However, Michigan does impose stringent limitations on expungement eligibility based on the length of the individual's record - that is, the number of convictions (nonconviction records like arrests are not relevant to eligibility). ${ }^{121}$ While this has now been loosened slightly, in the pre-20 I I version, expungements were strictly limited to people with exactly one conviction on a single charge. ${ }^{122}$ Prior convictions, subsequent convictions, and simultaneous convictions - even multiple charges stemming from the same incident - were all disqualifying. On a policy level, this has incongruous results; for example, a person with a single very serious felony may be eligible for an expungement, while a person with two simultaneous misdemeanor counts arising from one incident is not. However, the simple, bright-line nature of these eligibility requirements offers advantages from a research perspective; ${ }^{123}$ for example, it makes it easier to code expungement eligibility and other variables related to the nature of the criminal record.

For those meeting the eligibility requirements in Michigan, expungements are not automatic. Rather, the law requires the expungement seeker to go through an elaborate application process, which we describe in detail in section II.C. The court is not required to grant the requested expungement - it "may" grant the request if doing so is warranted by the applicant's subsequent behavior and "consistent with the public welfare." ${ }^{24}$ Still, grant rates are fairly high. Although our data do not identify unsuccessful applications, the Michigan State Police (MSP), which processes applications and also implements the expungements once they are granted, shared figures for 2016 and 2017 that indicate that approximately $75 \%$ of applications are successful. ${ }^{125}$

To carry out our study, we entered into a data-sharing agreement with multiple Michigan state agencies, which worked with us to develop a merged and de-identified dataset. MSP provided comprehensive Michigan criminal histories (RAP sheets) on almost every expunged criminal conviction in Michigan history through March 20I4, ${ }^{126}$ amounting to

121 Id. $\$ 780.62 \mathrm{I}(\mathrm{I})$ ("Except as provided in subsection (2), a person who is convicted of not more than I offense may file an application with the convicting court for the entry of an order setting aside the conviction."); see also People v. Blachura, 440 N.W.2d I, I-2 (Mich. Ct. App. I989) (person convicted of five counts of perjury ineligible since each count deemed a separate conviction).

122 See Мich. COMP. LAWS $\$ 780.62$ I (4)(c).

123 See Charles Tremper et al., Measuring Law for Evaluation Research, 34 Evaluation Rev. $242,252-54$ (2010).

124 MiCH. CoMP. LaWS. $\S 780.62 \mathrm{I}(9)$. Note that the text quoted has not changed. See I982 Mich. Pub. Acts I889.

125 Email from Ted Kilvington, Court Reporting Coordinator, Mich. State Police, to Simmon Kim, Research Assoc., Univ. of Mich. Empirical Legal Studies Ctr. (Feb. 22, 2019, I0:47 AM) (on file with authors). Although the figures MSP provided cover more recent years than do the data we use in our study, discussions with MSP and with expungement lawyers do not give us any reason to believe there have been substantial changes in grant rates in the intervening years.

126 A small share of the most recent records was inadvertently dropped, as we discuss below. 
nearly 30,000 cases, plus a larger group of other criminal records meeting requirements that we discuss below. These were linked to wage and employment information for the same individuals from the state Unemployment Insurance Agency and Workforce Development Agency. Matching was based on Social Security numbers, so those without such numbers are excluded from our analysis of wage data. ${ }^{127}$ In addition to the records for individuals who actually receive expungements, we obtained records for a large group of people who were, at the time of their convictions, potentially legally eligible for expungements in the future, if they subsequently succeeded in meeting the five-clean-years requirement. This group consists of individuals with a first criminal offense (occurring between 1999 and 2008) that was on a list of legally eligible offense codes, which we developed using the expungement statute and provided to the MSP for a data query. ${ }^{128}$

Our data have other limitations. For our criminal record and employment outcome data, we lack information on out-of-state convictions (affecting our coding of expungement eligibility and recidivism outcomes) and out-of-state income (affecting our wage and employment analysis). Our wage and employment information comes from the state unemployment insurance system, which covers wage and salary employees quite comprehensively but misses the self-employed and individuals employed "under the table."129

127 Michigan's Department of Technology, Management and Budget carried out the matching process, and then the department de-identified all records before it turned them over to us. In the initial stages of our work on this project, in order to shape our records requests for MSP, we also received and analyzed court records from Michigan's Judicial Data Warehouse. However, because of the incompleteness of these records, we did not include them in the ultimate data analysis.

128 Because MSP asked us to keep our request reasonable in size, we excluded from this list certain common petty misdemeanors - such as dog-leash law and hunting and fishing violations which are almost never expunged, even though they are legally eligible. We identified these as among Michigan's most common first offenses based on a preliminary analysis of court data from the Judicial Data Warehouse, but these offenses are essentially not found at all in the complete dataset on all expungements, perhaps suggesting that people do not bother to expunge records so minor that they may impose no serious burdens. Some cases were also inadvertently excluded because MSP formatted offense codes in inconsistent ways that did not match our list; these exclusions seem substantively random. We also excluded minor-in-possession cases, which in Michigan were (until the offense was decriminalized in 2016) often subject to a separate diversion process for youthful individuals. We discuss the implication of these exclusions below, infra pp. 2492-93.

129 This means that our measured employment and wage levels will be biased downward relative to total employment and wages. Although this is true to some degree both before and after expungement, it is possible that it is more true before expungement, if people with records are more likely to seek under-the-table work. If so, we could overstate true wage gains. On the other hand, there are reasons to focus on employment in the formal sector (as employment studies typically do). There are distinct advantages to having formal labor market opportunities (for example, termination notice and other mandatory benefits). See Minhaj Mahmud et al., What Aspects of Formality Do Workers Value? 3 (World Bank Grp., Knowledge and Strategy Team, Dev. Econ., Working Paper No. 9108, 2020), http://documents.worldbank.org/curated/en/428331578944574540/ pdf/What-Aspects-of-Formality-Do-Workers-Value-Evidence-from-a-Choice-Experiment-in- 
Our most serious data challenge involves missing records. The state's process for matching and de-identifying our criminal history and employment outcomes data inadvertently dropped certain observations. ${ }^{130}$ Fortunately, we were able to restore virtually all of the dropped records that concern expungement recipients because we had already received a complete version of that part of the dataset slightly earlier. ${ }^{131}$ These drops only minimally affect our uptake analysis and should not affect our employment analysis at all. However, the problem did lead us to focus our primary recidivism outcome analysis on expungement recipients alone, because the drops affect the accuracy of our recidivism measures for nonrecipients. ${ }^{132}$ Another data challenge relates to certain missing dates in the criminal records data, a problem that requires us to impute eligibility dates. ${ }^{133}$ We believe this adds fairly minimal measurement error. The imputation should not be far off, and should be correct on average, so our resulting uptake estimates should not be biased, even

Bangladesh.pdf [https://perma.cc/RM65-FDGY]. Indeed, to the extent that people do move from under-the-table work to formal employment after receiving an expungement, it is presumably because the formal-sector option is more appealing. We discuss these issues as they pertain to our analyses below.

130 Data patterns make clear that their procedure successfully identified duplicate records produced by overlapping data pulls by MSP but then mistakenly deleted both copies.

131 We were unable to restore some records for individuals who had not received expungements, however. By the time we diagnosed the problem, our data-sharing agreement and grant period had expired, and the state authorities informed us that they could not reconstruct the original dataset for us or repeat the process. Through information from MSP, we were able to identify the number of lost records (about $9 \%$ of the nonrecipients in the original data pull).

132 The dropped nonrecipient cases were individuals with at least two convictions, so omitting them would have distorted our analysis. We requested data on people with certain kinds of first convictions or second convictions within a ten-year period; people with first and second convictions meeting these criteria were included as duplicates and then doubly dropped. The other set of duplicates dropped was the set of expungement recipients who also met the eligibility criteria for the comparison group, but this was the set that we were able to restore.

133 When MSP effectuates an expungement, they change the disposition field in the record to denote an expungement, but their data entry system does not have a separate field for the expungement date. Instead, MSP's practice in most years was to change a field called "judgment date" to the expungement date. This practice caused the information originally stored in the judgment date field to be lost - specifically, the conviction date, which is what we use in most cases to calculate the start date for the five-year expungement eligibility clock. Expungement eligibility in nonincarceration cases runs from sentencing, which is usually a few weeks after the case disposition, Email from Jonathan Sacks, Appellate Def., State Appellate Defs.' Office, to Sonja Starr, Professor of Law, Univ. of Mich. Law Sch. (Feb. 22, 2019, Ir:02 AM) (on file with authors); Email from Kim Thomas, Clinical Professor of Law, Univ. of Mich. Law Sch., to J.J. Prescott, Professor of Law, Univ. of Mich. Law Sch. (Feb. I7, 2019, 9:I9 PM) (on file with authors), and has no recorded date in the data. MSP informed us, however, that when they make their official determinations of expungement eligibility, they rely on the conviction date as a proxy for sentencing, so we do the same here. See Email from Nick Romanov, IT Specialist, Mich. State Police, to J.J. Prescott, Professor of Law, Univ. of Mich. Law Sch. (Nov. 7, 2018, Ir:38 AM) (on file with authors). Because some of our analyses (especially of uptake rates) require us to know both the expungement eligibility date and the expungement grant date, we had to impute the lost conviction date based on the incident, arrest, and charge dates. 
if we might get the date of eligibility wrong by a month or two for some individual observations.

In a small subset of expungement cases, MSP changed the disposition code but did not change the judgment date field to the expungement date, leaving no record of when the expungement occurred. These cases are identifiable because the judgment date is too close to other key dates in the case (for example, the arrest date) to be a plausible expungement date given the required five-year waiting period. We eliminate these cases from the recidivism and employment analyses, which require expungement dates; the lag time from other events in the case to expungement receipt is far too unpredictable to be imputed without introducing significant measurement error. However, in our analyses of expungement uptake rates within certain periods of time, we cannot ignore these cases or we would understate uptake, so instead we make assumptions about their temporal distribution to estimate bounds on uptake rates. Fortunately, the practical importance of this problem is small; there is good reason to believe that most of these unknown-date expungements occurred after June $20 \mathrm{II}$, when we see a sudden drop in the number of known-date expungements to virtually zero, reflecting a change in MSP's data-recording practice. ${ }^{134}$ This date happens to coincide with the substantive changes in the expungement law that (as we note above) took place in $20 \mathrm{II},{ }^{135}$ and the focus of our work is on expungements taking place before that date anyway.

\section{The Uptake GaP: Who SeEKS AND RECEIVES EXPUNGEMENTS?}

Challenges surrounding uptake may be the most underappreciated problem concerning expungement policies — and indeed, similar problems appear in many access-to-justice contexts. ${ }^{136}$ Uptake challenges potentially arise whenever the government imposes significant burdens - such as fees or onerous administrative requirements - on the exercise of a right or opportunity, or whenever it is difficult for potential

134 MSP confirmed that expungement dates are not recorded in their current data and that the number of expungements granted has only increased since 20I I. See Email from Ted Kilvington, supra note I25 (stating that 2594 expungements were processed in 2017). Assuming expungement frequency at least did not drop, we believe at least half the unknown-date expungements in the earliest version of our complete expungement dataset (which ended in December 20I2) must have occurred between June 20I I and December 20I2, which leaves at most 3000 occurring before then (about I3\% of the number of known-date expungements).

135 See supra notes I I I-I I 4 and accompanying text.

136 See, e.g., J.J. Prescott, Assessing Access-to-Justice Outreach Strategies, I74 J. INSTITUTIONAL \& THEORETICAL ECON. 34, 36 (20I8) ("Individuals often fail to take full advantage of beneficial government programs and policies. This take-up problem has been studied in numerous contexts ...."). 
beneficiaries to learn about those rights or opportunities. ${ }^{137}$ And a right or opportunity that is too difficult for most people to exercise is effectively empty. Accordingly, in this Part, we address several questions surrounding expungement uptake (here defined as the successful receipt of an expungement by someone who is eligible to receive one), which have never previously been examined empirically. ${ }^{138}$

In section $\mathrm{A}$, we estimate the overall five-year expungement uptake rate among those who are eligible for such relief. In section B, we turn to the question of who successfully obtains expungements, presenting descriptive statistics on recipients and regression analyses to assess which individual and case characteristics predict expungement receipt. We use these analyses in section $\mathrm{C}$, along with qualitative insights provided by our interviews with expungement experts, to inform a discussion of uptake hurdles and their implications.

137 For a useful discussion of the "uptake" problem for social-benefit programs - referred to as the "take-up" problem in many disciplines - see generally Janet Currie, The Take-Up of Social Benefits, in PUBlic POLICY AND THE INCOME Distribution 80 (Alan J. Auerbach et al. eds., 2006).

138 Research on uptake is common in many contexts outside of the criminal justice domain, where policy designers are very conscious of the issue. See generally, e.g., Saurabh Bhargava \& Dayanand Manoli, Psychological Frictions and the Incomplete Take-Up of Social Benefits: Evidence from an IRS Field Experiment, ro5 AM. ECON. REv. 3489 (2015) (tax benefits); Adam S. Booij et al., The Role of Information in the Take-Up of Student Loans, 3I ECON. EDUC. REV. 33 (2012) (education); Jeffrey R. Kling et al., Comparison Friction: Experimental Evidence from Medicare Drug Plans, I 27 Q.J. ECON. I 99 (20I2) (health); Brigitte C. Madrian \& Dennis F. Shea, The Power of Suggestion: Inertia in $401(k)$ Participation and Savings Behavior, I I6 Q.J. ECON. I I49 (200I) (saving incentives); Giovanni Mastrobuoni, The Role of Information for Retirement Behavior: Evidence Based on the Stepwise Introduction of the Social Security Statement, 95 J. PUB. ECON. 9I 3 (201 I) (Social Security); Xiaopeng Pang et al., Does Women's Knowledge of Voting Rights Affect Their Voting Behaviour in Village Elections? Evidence from a Randomized Controlled Trial in China, $2 \mathrm{I} 3$ CHINA Q. 39 (2013) (voting rights); Dan Archer et al., Reducing Vulnerability to Human Trafficking: An Experimental Intervention Using Anti-trafficking Campaigns to Change Knowledge, Attitudes, Beliefs, and Practices in Nepal (U.S. Agency for Int'l Dev., Research and Innovation Grants Working Papers Series, 20I6) (legal access and compliance). This literature provides insight into the general barriers to uptake. For example, Janet Currie identifies the costs of learning about and making use of government programs, noting that these costs may be relatively high for individuals who need programs the most. Currie, supra note 137 , at 83 . Saurabh Bhargava and Dayanand Manoli emphasize the costs studied by behavioral economics, including psychological frictions due to cognitive, motivational, and emotional constraints. Bhargava \& Manoli, supra, at 3489-90. People may be confused about a program or policy, see, e.g., Jeffrey B. Liebman \& Richard J. Zeckhauser, Schmeduling 6-9 (2004) (unpublished working paper), https://scholar.harvard. edu/files/jeffreyliebman/files/Schmeduling_WorkingPaper.pdf [https://perma.cc/2EFP-VRCB], may be unaware that a particular program exists, see Currie, supra note I37, at IIO-II, or may suffer from other psychological biases or tendencies (such as procrastination, inattention, or distaste for time-consuming processes) that inhibit their pursuit of a program's benefits, see Marianne Bertrand et al., Behavioral Economics and Marketing in Aid of Decision Making Among the Poor, 25 J. Pub. Pol'y \& Marketing 8, io (2006); Madrian \& Shea, supra, at i 50 . Other explanations include hyperbolic time discounting and stigma costs. 


\section{A. Estimating Uptake Rates}

The first step in estimating expungement uptake rates is identifying which cases are legally eligible for relief. In our context, the relevant eligible pool is defined first by the parameters of the records query that we asked MSP to implement, as detailed in section I.D, and second by some further sample refinements that we carry out thereafter. These sample parameters are: (I) The individual has a first criminal conviction on a single criminal count. ${ }^{139}$ (2) The crime of conviction matches an offense code on a list of offenses eligible for expungement (known as a "set-aside" in Michigan). ${ }^{140}$ (3) Sentencing for the eligible count took place between January I999 and May 200I. ${ }^{141}$ (4) The individual is not subsequently convicted for any crime within five years of sentencing. ${ }^{142}$ (5) The individual was not sentenced to incarceration on the eligible offense. ${ }^{143}$ And (6) the individual has no out-of-state driver's license listed anywhere in their MSP arrest record. ${ }^{144}$

The five-year uptake rate is the percentage of this eligible group that receives an expungement within five years of the eligibility date (that is, within ten years of sentencing). We make two further assumptions in order to calculate this uptake rate, which relate to the data problems we identify above in section I.D. First, we assume the distribution of unknown-date expungements in our sample, in terms of the time elapsed since the case's disposition, is roughly similar to the distribution of

139 This was a pre-20 I eligibility requirement. See supra notes I I9, I 22 and accompanying text. As we describe below, we are able to screen only for prior offenses that took place in Michigan.

140 We are confident that our offense list only contains offenses that are in fact legally eligible for expungement. However, as we explain in section I.D and discuss below, our list is not inclusive of all eligible offenses.

141 Thus, expungement eligibility kicks in between January 2004 and May 2006 in our uptake sample. Our sample contains the most recent set of cases for which we can still track outcomes for five years after eligibility accrues. The main estimates we give are five-year uptake rates, and we treat May 20 I as the end of our tracking period because two important changes occurred in June 20I I: the eligibility rules changed (making more people eligible but also rendering some formerly eligible persons ineligible), and MSP ceased to record expungement dates. For cases receiving expungements, because of MSP's data recording practices, we impute the sentencing date.

142 This is also a legal requirement, and again we implement this filter based on Michigan data alone. See supra p. 2482 . Our eligible pool consists of people who became eligible after five years, and we estimate expungement receipt rates within the next five years. Some members of this sample could have lost eligibility at some point during the second five-year period due to a subsequent conviction, although as we will see in the recidivism analysis in Part III, this happens rarely.

143 We focus on nonincarceration cases (which, as we will see below, constitute the large majority of all expungement cases) because we have a more accurate measure of the start date of the eligibility clock, which runs from sentencing. In incarceration cases, the eligibility start date is based on release from incarceration, and because our data tell us only the sentence and not the actual release date, we cannot account for possible early release or credit for time served pretrial.

144 In our data, driver's license numbers have been removed, but for most observations we know whether the individual had a driver's license and, if so, the state that issued that license. We exclude individuals with out-of-state driver's licenses to reduce the likelihood of miscoding eligibility on account of unobservable out-of-state convictions, but we retain those observations of individuals who had no driver's license identified in our data. This restriction eliminates about $4 \%$ of our sample. 
known-date expungements. We show below that our empirical conclusions are robust to - that is, unaffected by - alternative assumptions about the unknown-date distribution. Second, we assume that the missing nonexpunged records would not have met the criteria for inclusion in this sample, and thus we do not adjust our estimate to account for them. We believe this latter assumption is largely correct; dropped cases all had at least two convictions within the years covered by the pool of eligible cases given to us by MSP (I 999-2008), few of which would meet the five-year nonrecidivism criterion. To the extent this assumption is mistaken, we understate the number of eligible cases and thus overestimate the uptake rate (but likely not by much).

In Table I, we present our main uptake estimate, which is discouragingly low. Of eligible individuals, only $6.5 \%$ receive expungements within five years of becoming eligible. The remaining $93.5 \%$ includes people who do not apply for expungements and those who have their applications denied by a judge. However, as we note above, we learned from MSP that in 2016 and 2017 combined, $74 \%$ of the expungement applications MSP received were ultimately granted by courts. If we assume that all of these applicants were legally eligible and that the same ratio applies during the relevant time period for our estimate (2004-II), $6.5 \%$ of those eligible for expungement receive one within five years, another $2.3 \%$ have their applications denied, and 91.2\% do not apply during the first five years of eligibility. This extrapolation may actually overstate the share of eligible people who apply for expungement, because some denials are based on ineligibility. ${ }^{145}$

In section $\mathrm{C}$, we discuss reasons for this poor uptake. But, first, how confident can we be in our principal estimate? In particular, given that our sample is both overinclusive and underinclusive in some ways, is our main uptake estimate for this sample a good proxy for expungement uptake for the full eligible population during these years? ${ }^{146}$ To inform this question, the remaining rows of Table I present estimates based on alternative assumptions and sample definitions. Given that we find very low uptake, we use the term "conservative" below to refer to assumptions that likely lead to an overestimation of uptake.

First, in Rows 2 and 3 of Table I, we alter our timing assumption for the unknown-date expungements. Ninety such cases appear in this sample. Our initial assumption that their timing distribution mirrors that of known-date expungements is conservative; there is a strong reason to believe that these expungements occur disproportionately after

145 Telephone Interview with Tracey Brame, Associate Dean, Cooley Law Sch. (Mar. I I, 20I9) (on file with authors).

146 In a similar study on uptake rates in the context of food stamp programs, the authors note that "program takeup rates estimated from social science data sets with limited asset measures can easily be mismeasured, and are likely to be too low." Beth Osborne Daponte et al., Why Do LowIncome Households Not Use Food Stamps? Evidence from an Experiment, 34 J. HUM. RESOURCES 612, 622 (I999); see also id. at 622-24. 
TABLE 1. UPTAKE RATES

Receipt of Expungement Within Five Years of Eligibility

\begin{tabular}{lcc}
\hline \multicolumn{1}{c}{ Specification } & $\begin{array}{c}\text { Five-Year } \\
\text { Uptake }\end{array}$ & $\begin{array}{c}\text { Sample Size } \\
\text { (n) }\end{array}$ \\
\hline 1. Main & $6.55 \%$ & 9103 \\
2. Expungement Date Unknown: Lower Bound & $5.73 \%$ & 9103 \\
3. Expungement Date Unknown: Upper Bound & $6.72 \%$ & 9103 \\
4. Including Incarcerated ( $\leq 1$ year) & $5.44 \%$ & 14,223 \\
\hline \hline
\end{tabular}

Notes: The uptake sample $(\mathrm{n}=9103)$ consists of all individuals who have a first conviction on a single criminal count in Michigan for an expungement-eligible crime with a sentencing date between January 1999 and May 2001, and who were not incarcerated, were not reconvicted for any crime within five years of sentencing, and did not have an out-of-state driver's license. The sample for Row $4(n=14,223)$ adds individuals who were incarcerated for their expungement-eligible offense for up to one year and were released by May 2001.

May 20I I (and therefore after the five-year period), when MSP stopped changing the disposition dates in their records. We estimate bounds on the possible scope of any error from this assumption. If we assume that none of the unknown-date expungements occurred within five years of eligibility, or, instead, we apply the most conservative assumption (that they all occurred within five years), the resulting uptake estimates range from only $5.7 \%$ to $6.7 \%$. Because our original approach is conservative, we assume that the correct uptake rate (if all other assumptions are valid, that is) lies somewhere between $5.7 \%$ and $6.5 \%$.

In Row 4, we add to the sample all cases involving incarceration of up to one year, testing the effect of our exclusion of these observations. We assume that these individuals served their full term of incarceration, commencing on the date of sentencing. This assumption is also conservative because it ignores credit for time served and possible early release; it thus errs on the late side in estimating the release date and may include slightly more than five years of eligible time in the "fiveyear uptake" estimate. After adding these cases to the sample, the uptake rate drops to $5.4 \%$, indicating that people who have been sentenced to incarceration receive expungements at lower rates than other eligible people. Thus, focusing on nonincarceration cases has the effect of increasing our main uptake estimate. We do not include a five-year estimate for those serving longer incarceration terms because we do not have a sufficient follow-up period for most of these cases. However, given the evidence that those who were incarcerated for relatively short terms have a lower uptake rate, it seems likely that including individuals with longer incarceration terms would only lower the rate further.

There are a few uncertainties about our uptake estimates that we cannot address directly with our data. In particular, we have no records 
of out-of-state or federal convictions, and so our "eligible" pool probably includes some people who are not in fact eligible due to such convictions. Our exclusion of people with out-of-state licenses mitigates this problem but does not eliminate it, as people can move or commit crimes across borders. Including ineligible cases in the eligible pool will produce an underestimate of the uptake rate.

However, back-of-the-envelope calculations suggest that this problem is minor. The Census Bureau estimates that about r.8\% of lowerincome Midwestern households (the best available proxy for our sample) move across state lines each year. ${ }^{147}$ When we apply this rate of attrition to our sample and extrapolate from the within-Michigan reconviction patterns in our data, we deduce that we might fail to observe disqualifying reconvictions within five years for about $\mathrm{s} \%$ of the purportedly eligible population. ${ }^{148}$ We have a similar problem with potentially disqualifying prior adult convictions for people who might have previously lived elsewhere; this problem might be twice as large or so as that of subsequent convictions, given the age distribution of our sample. It is also possible for Michigan residents to commit crimes in other states, although the great majority of crimes are committed very close to home; we estimate that we might miss prior or subsequent cross-border convictions for perhaps another $7 \%$ or $8 \%$ of the sample. ${ }^{149}$ All in all, missing out-of-state convictions likely cause us to overstate the size of the eligible group by no more than 10\% to I $2 \%$, and therefore to understate

147 See Geographical Mobility: 2017 to 2018 tbl.9, U.S. Census Bureau (Nov. 20I8), https://www2.census.gov/programs-surveys/demo/tables/geographic-mobility/20I8/cps-2018/tabo9. xls [https://perma.cc/69NN-JP 39$]$. I.8\% is based on households with incomes at $\$ 34,999$ per year or below. Id. If we use individual-level Census data instead, the interstate mobility estimate is even lower - closer to I.5\%. See id.

148 To make this calculation, we assume that, per the state issuing their driver's licenses, our sample members were Michigan residents at the time of their convictions. The mobility estimate implies that $7.3 \%$ of our sample would have moved away from Michigan after five years; for that subgroup, we would miss on average the last 2.5 years of their criminal history. In our sample, those who are not reconvicted within 2.5 years have a reconviction rate of $13 \%$ over the next 2.5 years; $13 \%$ times $7.3 \%$ is about $\mathrm{I} \%$.

149 A large body of research finds that the average distance from an individual's home to the location of their crime is around one or two miles. See Michael Townsley \& Aiden Sidebottom, All Offenders Are Equal, but Some Are More Equal than Others: Variation in Journeys to Crime Between Offenders, 48 CRIMINOLOGY 897, 899-900 (20I0) (reviewing literature). One piece of evidence that most crimes are committed in-state comes from our own data: among arrestees with driver's licenses, $96 \%$ are from Michigan. If we make the conservative assumption that all of the balance are out-of-state residents (not just people with old licenses from a state of previous residence) and we assume conversely that about $96 \%$ of the recidivism committed by Michigan residents is in-state (not a necessary inference but a plausible approximation), it would imply that we overlook reconvictions before five years in about $2.7 \%$ of our sample. We could also miss prior convictions over a somewhat longer period (eleven years on average in our sample), some of which would presumably have involved the same individuals. 
the uptake rate by less than one percentage point. Meanwhile, the federal conviction problem is likely small enough to be ignored because federal convictions are extremely rare relative to state convictions. ${ }^{150}$

In addition, our eligible pool of people with records is defined by the parameters of the data query that MSP conducted on our behalf, which, as we discuss in section I.D, is itself limited by the list of statutory offense codes of the eligible crimes that we provided. ${ }^{151}$ This source of error likely cuts in the opposite direction, causing us to overestimate uptake, because the largest category of legally eligible offenses that we exclude from the list are petty offenses that we know are very common first offenses in Michigan but are almost never expunged. ${ }^{152}$ If we were to include them, the uptake rate we estimate would be lower. Although we inadvertently omit some additional observations due to irregular formatting of statutory codes, these exclusions are very likely effectively random - that is, there is no reason to expect that the observations with irregular formatting have either higher or lower uptake rates compared to the rates of those we include in the sample.

Overall, we are confident that our main five-year uptake estimate of $6.5 \%$ is quite accurate for our sample, and it is in the ballpark of the correct figure for the true population of eligible individuals in Michigan during the years in question (2004-II); our best guess is that the true uptake rate is probably lower. While the lack of data from out-of-state and federal courts may bias our estimate downward, these biases cannot be very large. Meanwhile, the assumptions we make about the missing cases and the unknown expungement dates are designed to bias our uptake estimate upward, and our constraints on the statutory code and the exclusion of cases with incarceration terms almost surely do so as well. In any event, the substantive story on uptake from our data is clear: very

\footnotetext{
150 The federal district courts in Michigan sentenced I233 people for felonies or nonpetty misdemeanors in 20I7. U.S. SENTENCING COMM'N, STATISTICAL INFORMATION PACKET FISCAL YEAR 20I7: STATE OF MICHIGAN 4 tbl.2, https://www.ussc.gov/sites/default/files/pdf/ research-and-publications/federal-sentencingstatistics/state-district-circuit/20I7/mi 7 .pdf [https:// perma.cc/PB 74-PYQW]. By comparison, in 2017 , caseload figures suggest that the Michigan state courts entered roughly 340,000 criminal convictions of any sort. See MiCH. COURTS, 2017 COURT CASELOAD REPORT I I, https://courts.michigan.gov/education/stats/Caseload/20I $7 /$ Statewide.pdf [https://perma.cc/3 $\mathrm{EXJ}-9 \mathrm{YLF}$. This figure is based on adding felony and misdemeanor (including traffic) guilty pleas and trial verdicts in circuit and district courts, under the rough estimate that $80 \%$ of trial verdicts are convictions. The Michigan Department of Corrections reported approximately 47,000 people convicted of felonies entering corrections in 20I6. See Kahryn Riley, Coping with the Growing Number of Felons in Michigan, MACKINAC CTR. FOR PUB. POL'y (Aug. 27 , 20I8), https://www.mackinac.org/coping-with-the-growing-number-of-felons-in-michigan [https://perma.cc/ $\left.\mathrm{C}_{5} \mathrm{UR}-\mathrm{T}_{7} \mathrm{UV}\right]$. Although these numbers are not precisely comparable, the difference in scale is obvious and suggests that only a very small percentage of the single-Michiganconviction individuals in our sample are likely to have a federal record, making a negligible difference in our uptake estimates.

151 See supra note 128.

152 See id.
} 
few of those who are legally eligible for expungements receive them within five years of becoming eligible. Indeed, even if the true five-year rate were 10\% - substantially higher than any version of our estimate - it would still be strikingly low.

What about after five years? Unfortunately, we cannot directly estimate a longer-term uptake rate because of the time range of our data on the eligible-group sample. However, we do have data on the full universe of expungement recipients in Michigan up through 20I I. Among nonincarceration cases in this more inclusive sample, at the time of expungement receipt, $44 \%$ have an elapsed time since eligibility of more than five years. ${ }^{153}$ Assuming the same pattern holds for the cases in our eligible sample, extrapolating from our main uptake estimate would predict a lifetime uptake rate of I . $6 \%$ for those not sentenced to incarceration. ${ }^{154}$ Even this rate means that $88 \%$ of those eligible will never secure relief - and those who receive expungements after many years still forfeit many years of potential benefits.

\section{B. Who Receives Expungements?}

Only a small minority of people with records in Michigan are eligible for expungements, ${ }^{155}$ and only a small minority of this eligible population in fact receives them. What distinguishes eligible individuals who receive an expungement from those who do not? To develop insight into possible reasons for the low uptake rate we identify and to develop hypotheses about policies that might increase it, we assess the characteristics of the individuals who do receive expungements and their cases, and we investigate which of those characteristics are usefully predictive of an eligible person receiving an expungement.

In Table 2, we provide descriptive statistics of the relevant populations for this exercise. The statistics in Column I refer to the complete population of all Michigan expungement recipients with known dates prior to June 20II (when the law changed). Columns 2 and 3 report summary statistics for the main sample we use in our uptake-rate analysis on display in Table I. Column 2 covers individuals within that sample who did receive expungements within five years of becoming eligible, and Column 3 covers the entire uptake sample (most of whom did not receive expungements). Columns 2 and 3 can be usefully compared to one another to shed light on how expungement recipients differ from the broader eligible group. We note that some of the figures for

153 See infra fig. I and accompanying text.

154 That is, we simply assume that the $6.5 \%$ share of the uptake sample who receive expungements within five years constitute $56 \%$ of those who will eventually receive expungements in their lifetimes: $0.065 / 0.56=0.1 \mathrm{I} 6$.

155 Establishing the number of people with criminal records is notoriously difficult. Expungement advocates consistently emphasized to us in interviews that very few people are actually eligible, which is intuitive, given the strict limitations in terms of numbers of convictions (especially during the pre20I I period). See infra notes 204-2 I 2 and accompanying text for further analysis. 
TABLE 2. DEMOGRAPHIC CHARACTERISTICS OF EXPUNGEMENT RECIPIENTS

\section{(1)}

Expungement Recipients (complete population)

\section{(2)}

\begin{tabular}{|c|c|c|c|}
\hline & $\begin{array}{l}\text { Expungement } \\
\text { Recipients } \\
\text { (complete } \\
\text { population) }\end{array}$ & $\begin{array}{c}\text { Expungement } \\
\text { Recipients } \\
\text { (uptake sample } \\
\text { only) }\end{array}$ & $\begin{array}{c}\text { Eligible for } \\
\text { Expungement } \\
\text { (uptake sample } \\
\text { only) }\end{array}$ \\
\hline \multicolumn{4}{|l|}{ Individual Characteristics } \\
\hline \multicolumn{4}{|l|}{ Race } \\
\hline Black & $30.4 \%$ & $39.8 \%$ & $30.9 \%$ \\
\hline White & $65.6 \%$ & $54.4 \%$ & $67.0 \%$ \\
\hline Other & $4.0 \%$ & $5.7 \%$ & $2.1 \%$ \\
\hline Mean Age at Conviction (years) & 26.50 & 29.64 & 30.43 \\
\hline Male & $60.9 \%$ & $54.2 \%$ & $64.9 \%$ \\
\hline Employed (at eligibility) & $66.0 \%$ & $67.0 \%$ & $64.6 \%$ \\
\hline Employed (before expungement) & $60.6 \%$ & $53.8 \%$ & \\
\hline Quarterly Wages (at eligibility) & $\$ 4,968$ & $\$ 5,013$ & $\$ 6,387$ \\
\hline Quarterly Wages (before expungement) & $\$ 5,160$ & $\$ 3,463$ & \\
\hline \multicolumn{4}{|l|}{ Case Characteristics } \\
\hline Felony & $44.2 \%$ & $48.9 \%$ & $30.1 \%$ \\
\hline \multicolumn{4}{|l|}{ Crime Type } \\
\hline Violent & $14.9 \%$ & $28.0 \%$ & $26.2 \%$ \\
\hline Drug & $13.5 \%$ & $14.0 \%$ & $27.0 \%$ \\
\hline Property/Economic & $53.2 \%$ & $39.8 \%$ & $31.6 \%$ \\
\hline Other & $18.4 \%$ & $18.2 \%$ & $15.2 \%$ \\
\hline Incarcerated & $28.6 \%$ & & \\
\hline Incarcerated ( > 1 year) & $1.9 \%$ & & \\
\hline Median Elapsed Time (years) & 9.6 & & \\
\hline Number of Observations & 22,004 & 522 & 9103 \\
\hline \multicolumn{4}{|c|}{$\begin{array}{l}\text { Notes: Column (1) includes the complete population of Michigan known-date expungement recipients through } \\
\text { May 2011. Column (2) comprises all individuals in the uptake sample who received an expungement. The uptake } \\
\text { sample (n=9103) in Column (3) consists of all individuals who have a first conviction on a single criminal count in } \\
\text { Michigan for an expungement-eligible crime with a sentencing date between January } 1999 \text { and May } 2001 \text {, and } \\
\text { who were not incarcerated, were not reconvicted for any crime within five years of sentencing, and did not have } \\
\text { an out-of-state driver's license. The phrases "at eligibility" and "before expungement" refer to the quarter in } \\
\text { which an individual first becomes eligible for expungement and the quarter before expungement, respectively. } \\
\text { "Median Elapsed Time" is the number of years between sentencing and expungement receipt. }\end{array}$} \\
\hline
\end{tabular}


expungement recipients look a little bit different in Columns I and 2; this may arise from the various constraints on the Column 2 sample.

While expungement recipients have diverse personal and case characteristics, some patterns stand out in the data. Relative to the criminal convictions of the entire eligible pool (as shown in Column 3), convictions that are actually expunged (as shown in Column 2) are much more likely to be felonies; they are more likely to be property offenses, less likely to be drug crimes, and roughly equally likely to be violent offenses. Although expungements are not limited to minor crimes under the law we study, most expungement recipients were not sentenced to incarceration for their expunged offense. In fact, among all expungement recipients historically, only $28.6 \%$ were incarcerated for any time at all, and only I.9\% were incarcerated for more than one year. ${ }^{156}$ Finally, compared to all eligible individuals, expungement recipients are less likely to be male and more likely to be black.

Figure I. Time ElAPSED BETWEEN SENTENCING AND EXPUNGEMENT

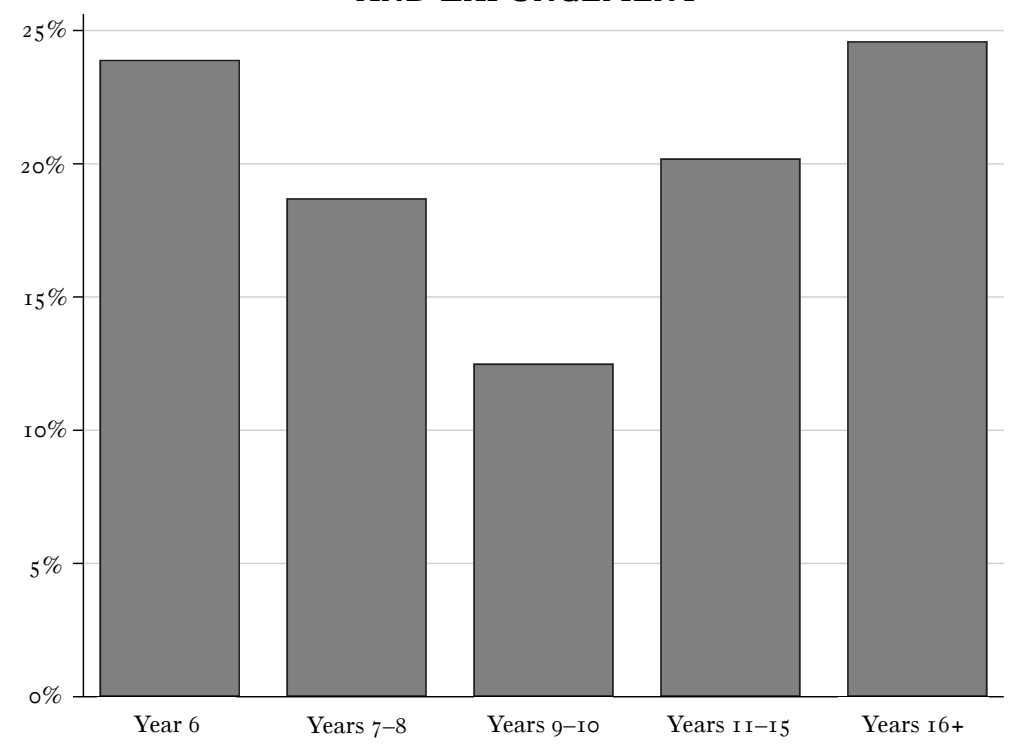

Notes: The bars show the percentage of recipients who received their expungement before the end of the year(s) indicated and who did not receive it in an earlier period. The sample consists of the complete population of Michigan known-date expungement recipients through May 20 I I $(n=22,004)$.

156 Because our main uptake sample is defined to exclude those who were incarcerated, we do not provide comparison figures in Columns 2 and 3 . 
We report employment measures for both the quarter that the recipient became eligible for the expungement and the quarter before actually receiving it, which may offer suggestive evidence about whether employment changes influence the timing of expungement applications. ${ }^{157}$ Here, we discern notable differences between the uptake sample and the full sample of expungement recipients: in the former, employment rates and wages are far lower just before expungement than they were at the time of eligibility, whereas in the full sample employment is modestly lower and average wages are actually higher. This difference may reflect the fact that the uptake sample is narrowly defined temporally, and the five-year observation period for the uptake outcome (ending between 2009 and 20 I I for all members of the sample) includes a major economic crash; ${ }^{158}$ for this reason, these numbers may not actually suggest any broader relationship between employment setbacks and expungement timing. We explore that potential relationship in Part IV.

As Column I in Table 2 shows, at the time of expungement receipt, the median time elapsed since sentencing is 9.6 years. ${ }^{159}$ In Figure I, we show more detail on the distribution of elapsed time, focusing on those not sentenced to incarceration, all of whom would have become eligible after five years had transpired. Figure i makes clear that there is wide variation in the time lag between eligibility and expungement receipt. On the one hand, the single year with by far the most expungements granted is the first year after the five-year waiting period expires (that is, the sixth year since sentencing - labeled "Year 6"), roughly a quarter of the total. This flurry of expungement activity suggests a pentup demand effect: some expungement recipients likely anticipate becoming eligible ahead of time and apply more or less as soon as they can. ${ }^{160}$ The monthly rate, not shown in the graph, peaks at four months after the date of eligibility; this too is consistent with the pent-up demand theory, since expungements typically take a few months to process. ${ }^{161}$

157 We discuss our wage data in more detail infra Part IV, pp. 2523-43.

158 See generally Chart Book: The Legacy of the Great Recession, CTR. ON BUDGET \& POL'Y PRIORITIES (June 6, 20I9), https://www.cbpp.org/research/economy/chart-book-the-legacy-of-thegreat-recession [https://perma.cc/ ${ }_{9} \mathrm{~K}_{74}-\mathrm{N}_{79} \mathrm{U}$ ] (reviewing the economic consequences of the recession of 2007-09).

159 We do not show this figure in Column 2 because that sample is already constrained to include only those receiving expungements within five years of becoming eligible.

$160 \mathrm{Cf}$. Jennifer Gerarda Brown, Competitive Federalism and the Legislative Incentives to Recognize Same-Sex Marriage, 68 S. CAL. L. REv. 745, 754-59 (I995) (analyzing the potential benefits of same-sex marriage legalization using a model assuming pent-up demand).

161 See Telephone Interview with Michael Kiehne, Attorney, Mich. Legal Help (Feb. I4, 20I9) (estimating that four to six months is typical for one large Michigan county); Telephone Interview with Chioke Mose-Telesford, Deputy Dir. of Workforce Dev. for the City of Detroit (Feb. 27, 2019) (explaining that Detroit's legal assistance program has recently reduced its wait time to two months through concerted efforts to accelerate the process but that previously i6o to I 90 days would have been typical). MSP advised us that typically about six to ten weeks elapse after MSP runs the criminal background check and returns a report deeming the individual eligible before the expungement is granted by the judge. Email from Ted Kilvington, supra note I 25. 
The annual rate declines continuously thereafter (the last two bars in the graph are taller only because they represent periods of five or more years). Still, more than $44 \%$ of expungements take place after more than five years of eligibility (year I I or beyond), and almost $25 \%$ occur after more than ten years of eligibility (year I 6 or beyond).

Figure 2. UPTAKe Rate by County (Michigan)

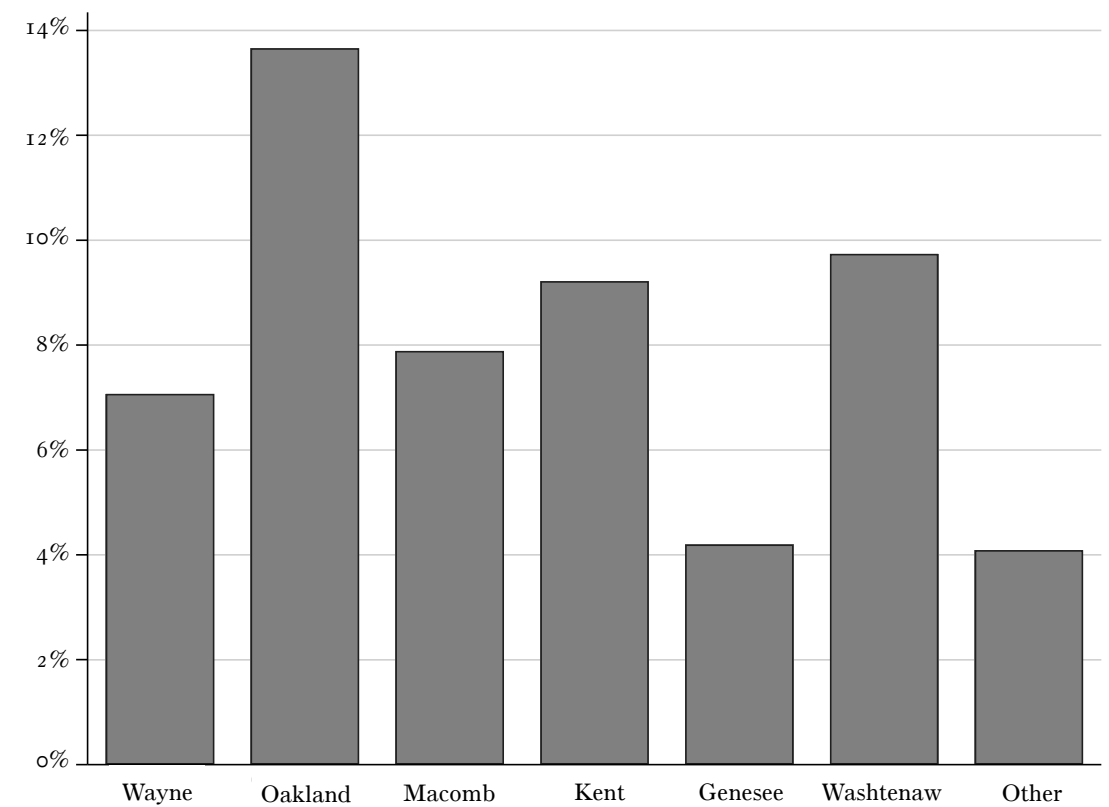

Notes: The bars indicate the percentage of expungement recipients by county. The sample consists of all individuals who have a first conviction on a single criminal count in Michigan for an expungement-eligible crime with a sentencing date between January I 999 and May 200I, and who were not incarcerated, were not reconvicted for any crime within five years of sentencing, and did not have an out-of-state driver's license (n=9103).

In Figure 2, we present uptake rates by county for the six most populous counties in Michigan (in descending order of population from the left), and for Michigan's other seventy-seven counties combined. The figure reveals considerable local variation. Michigan's largest counties are primarily urban and suburban; five of the six (all but Kent) are in Southeastern Michigan, within an hour of Detroit. Nevertheless, Oakland County's rate is more than triple that of Genesee County, which it borders. All of the larger counties have higher uptake rates than the rest of the state combined. However, by 2014 , courts in every county in Michigan had granted at least one expungement, and at least ten had been granted in seventy-seven out of eighty-three counties (with the remaining six all being among Michigan's least populous).

Many of the individual and case characteristics listed in Table 2 are correlated with one another, and with the county as well, which makes 
TABLE 3. DETERMINANTS OF EXPUNGEMENT RECEIPT

\begin{tabular}{|c|c|c|c|c|c|}
\hline & \multicolumn{3}{|c|}{$\begin{array}{c}\text { Receipt: } \\
\text { Within Five Years of Eligibility }\end{array}$} & \multicolumn{2}{|c|}{$\begin{array}{c}\text { Receipt: } \\
\text { Current Quarter }\end{array}$} \\
\hline & $(1)$ & (2) & (3) & (4) & $(5)$ \\
\hline Male & $\begin{array}{l}0.663 * * * \\
(0.064)\end{array}$ & $\begin{array}{l}0.654 * * * \\
(0.067)\end{array}$ & $\begin{array}{l}0.671 * * * \\
(0.058)\end{array}$ & $\begin{array}{l}0.693 * * * \\
(0.051)\end{array}$ & $\begin{array}{l}0.692 * * * \\
(0.052)\end{array}$ \\
\hline Black & $\begin{array}{l}0.989 \\
(0.109)\end{array}$ & $\begin{array}{l}0.825 \\
(0.098)\end{array}$ & $\begin{array}{l}0.846^{+} \\
(0.086)\end{array}$ & $\begin{array}{l}0.936 \\
(0.079)\end{array}$ & $\begin{array}{l}0.948 \\
(0.083)\end{array}$ \\
\hline Age at Conviction (years) & $\begin{array}{l}0.988^{* *} \\
(0.004)\end{array}$ & $\begin{array}{l}0.986 * * \\
(0.004)\end{array}$ & $\begin{array}{l}0.986 * * * \\
(0.004)\end{array}$ & $\begin{array}{l}0.988 * * * \\
(0.003)\end{array}$ & $\begin{array}{l}0.990 * * \\
(0.003)\end{array}$ \\
\hline Felony & $\begin{array}{l}2.552 * * * \\
(0.284)\end{array}$ & $\begin{array}{l}2.129 * * * \\
(0.262)\end{array}$ & $\begin{array}{l}2.211 * * * \\
(0.227)\end{array}$ & $\begin{array}{l}2.262 * * * \\
(0.194)\end{array}$ & $\begin{array}{l}2.446 * * * \\
(0.219)\end{array}$ \\
\hline \multicolumn{6}{|l|}{ Offense Type } \\
\hline Violent Offense & $\begin{array}{l}0.464 * * * \\
(0.068)\end{array}$ & $\begin{array}{l}0.545 * * * \\
(0.085)\end{array}$ & $\begin{array}{l}0.525 * * * \\
(0.070)\end{array}$ & $\begin{array}{l}0.554 * * * \\
(0.064)\end{array}$ & $\begin{array}{l}0.571 * * * \\
(0.069)\end{array}$ \\
\hline Drug Offense & $\begin{array}{l}1.243 \\
(0.170)\end{array}$ & $\begin{array}{l}1.487 * * \\
(0.221)\end{array}$ & $\begin{array}{l}1.306^{*} \\
(0.171)\end{array}$ & $\begin{array}{l}1.400 * * \\
(0.150)\end{array}$ & $\begin{array}{l}1.468 * * * \\
(0.164)\end{array}$ \\
\hline Public Order/Other Offense & $\begin{array}{l}1.272 * \\
(0.153)\end{array}$ & $\begin{array}{l}1.297^{+} \\
(0.175)\end{array}$ & $\begin{array}{l}1.331^{*} \\
(0.150)\end{array}$ & $\begin{array}{l}1.387 * * * \\
(0.128)\end{array}$ & $\begin{array}{l}1.449 * * * \\
(0.140)\end{array}$ \\
\hline Incarcerated $(\leq 1$ year $)$ & & & $\begin{array}{l}0.553 * * * \\
(0.057)\end{array}$ & $\begin{array}{l}0.676 * * * \\
(0.057)\end{array}$ & $\begin{array}{l}0.672 * * * \\
(0.058)\end{array}$ \\
\hline Wages (last quarter) & & & & $\begin{array}{l}1.004 \\
(0.007)\end{array}$ & \\
\hline Employed (last quarter) & & & & $\begin{array}{l}1.768 * * * \\
(0.158)\end{array}$ & \\
\hline Lost Wages (last quarter) & & & & & $\begin{array}{l}2.268 * * * \\
(0.196)\end{array}$ \\
\hline Baseline Odds & $\begin{array}{l}0.077 * * * \\
(0.013)\end{array}$ & $\begin{array}{l}0.187 * * * \\
(0.048)\end{array}$ & $\begin{array}{l}0.120 * \\
(0.127)\end{array}$ & $\begin{array}{l}0.006 * * * \\
(0.006)\end{array}$ & $\begin{array}{l}0.011 * * * \\
(0.011)\end{array}$ \\
\hline \multicolumn{6}{|l|}{ Controls } \\
\hline Conviction Year Effects & $\mathrm{X}$ & $\mathrm{X}$ & $\mathrm{X}$ & $\mathrm{X}$ & $\mathrm{X}$ \\
\hline $\begin{array}{l}\text { County Effects } \\
\text { Elapsed Time (years) }\end{array}$ & & $\mathrm{X}$ & $\mathrm{X}$ & $\begin{array}{l}X \\
X\end{array}$ & $\begin{array}{l}\mathrm{X} \\
\mathrm{X}\end{array}$ \\
\hline Number of Observations & 9080 & 8406 & 13,465 & 515,964 & 474,670 \\
\hline
\end{tabular}


inference from this table fraught. It could be, for instance, that the higher uptake rate for black individuals can be entirely explained by county-to-county variation; indeed, uptake rates are generally lower in more rural, predominantly white Michigan counties. For this reason, in Table 3, we turn to regression analysis to test which individual and case characteristics remain predictive of expungement uptake when we hold other characteristics constant. We use logistic regression, a common approach for analyzing binary outcomes like expungement receipt. ${ }^{162}$ We present our results as odds ratios, which represent a multiplier of the odds of the expungement occurring. An odds ratio greater than one means that the variable is associated with increased odds of expungement receipt when other variables are fixed. ${ }^{163}$ In Columns I through 3 of Table 3, we study the determinants of whether an individual receives an expungement within five years of becoming eligible - the same outcome we report in Table ${ }^{1} .{ }^{164}$ We estimate the following equation:

$$
\begin{gathered}
\operatorname{logit}\left(\text { FiveYearUptake }_{i}\right)=\alpha+\beta_{1} \text { Male }_{i}+\beta_{2} \text { Black }_{i}+\beta_{3} \text { ConvAge }_{i} \\
+\beta_{4} \text { Felony }_{i}+\gamma_{c} \text { CrimeType }_{c i}+\delta_{y} \text { ConvYear }_{y i}+\epsilon_{i} .
\end{gathered}
$$

The outcome variable FiveYearUptake is an indicator for whether the individual receives an expungement within five years of eligibility. Male and Black depict the individual's reported gender and race; all nonblack races are combined into one base category, which is $94 \%$ white. ConvAge is the individual's age in years at the time of the expungementeligible conviction. ConvYear represents the year of that conviction. Felony is an indicator for whether the crime of conviction is a felony, and CrimeType is a set of indicators for the type of crime: drug-related, violent, and other, with property/economic crimes as the omitted reference category. Column I presents our baseline results. In Column 2 (and subsequent columns), we also control for county effects. In Column 3 , we include individuals incarcerated for their crime for up to one year and add an indicator for whether the individual was incarcerated.

162 However, linear (ordinary least squares) regression analysis produces substantively indistinguishable results when compared to the marginal effects from the logistic regressions.

163 Odds have a technical definition, and while they are not the same as probability, higher odds do mean a higher probability. When probabilities are quite low (as they are here), the odds ratio is a good rough approximation of the probability ratio. The odds that an event $X$ (for example, an expungement) occurs are equal to the probability that $X$ occurs divided by the probability that $X$ does not occur. An odds ratio refers to the multiplier of these odds that applies with a one-unit change in some explanatory variable.

164 For Columns I and 2 of Table 3, the sample is the same one we use for the main uptake estimate in Table I (with constraints described in section II.A), and for Column 3, we add cases with incarceration up to one year (the same sample we use in Table I, Row 4). Our results are robust to estimating Columns I through 3 on the same sample (in two different ways). The findings in Column 4 are also unaffected by limiting the analysis to Column 5 's smaller sample. These results are available upon request. 
The regression results in Column I show that, other things equal, uptake rates are much higher among women and among people who were relatively young at the time of their conviction. The impression given in Table 2 of a higher uptake rate for black individuals completely disappears in these regressions, implying that this racial difference is actually explained by other correlated characteristics. As for crime attributes, the regressions all confirm that people with felony convictions have, other things equal, more than twice the odds of receiving expungements. By contrast, people who have been incarcerated (even for short periods) and people convicted of violent crimes have only about half the odds of expungement receipt as otherwise similar individuals do; this pattern is not apparent in the summary statistics in Table 2. A possible theory for these results is that felony convictions make individuals much more likely to apply (because felonies can trigger a wider range of collateral consequences), but judges are less likely to grant expungements in cases involving more serious or violent convictions. ${ }^{165}$ Taken together, the pattern indicates that the people most likely to receive expungements are those with relatively minor felony convictions (especially women) - namely, felonies not resulting in jail time.

The regression results we present in Columns 4 and 5 also analyze expungement receipt, but they replace the five-year uptake indicator with a different outcome variable: whether an expungement is received in any particular quarter. These analyses help us to understand the influences on expungement probability that vary over time - and in particular, to ask whether an individual's immediate employment history (such as a recent job loss) drives the decision to apply for an expungement. The dataset we use in these regressions has a panel structure, meaning it contains separate observations for each quarter for each individual. The sample covers most of the people we include in the Column 3 analysis, depending on whether we have linked wage data for them. The regression we estimate takes the following form:

$$
\begin{gathered}
\operatorname{logit}\left(\text { SetAsideReceipt }_{i t}\right)=\alpha+\beta_{1} \text { Male }_{i}+\beta_{2} \text { Black }_{i}+\beta_{3} \text { ConvAge }_{i} \\
+\beta_{4} \text { Felony }_{i}+\beta_{5} \text { Incarcerated }_{i}+\gamma_{c} \text { CrimeType }_{c i} \\
+\delta_{y} \text { ConvYear }_{y i}+\mu_{s} \text { Count }_{s i}+\theta \text { EmplPrevQtr }_{i t} \\
+\pi \text { WagePrevQtr }_{i t}+\text { oTimeElapsed }_{i t}+\epsilon_{i t} .
\end{gathered}
$$

The specifications underlying Columns 4 and 5 are similar to the ones in the previous columns but also include variables that change over time for a given individual. Column 4 includes whether an individual was employed in the previous quarter (that is, whether any wages are reported, which we discuss in greater detail in Part IV) and their reported wages in the previous quarter, as well as the number of years that have elapsed since the expungement-eligible conviction. We focus 
on the role of the previous quarter in part because there is likely to be at least a one-quarter lag between expungement application and receipt, and we are interested in understanding the motivation for the application. In addition, lagging this variable avoids the problem of reverse causation: employment status and wages in the quarter of expungement receipt could be affected by the expungement itself.

In Column 5, we focus on whether the individual recently experienced an employment setback, which we proxy for with an indicator for whether the individual's wages had, in the quarter preceding the receipt of the expungement, dropped by at least $20 \%$ compared to a year earlier (denominated "Lost Wages" in Table 3). Our framework allows us to assess the effects of wage loss on expungement receipt in a way that is not confounded by the recession's timing. The whole sample is affected by the same economic trends, and the controls for year of conviction and years since conviction (which together produce the calendar year) also absorb those effects. The regression thus allows us to investigate whether, among individuals subjected to the same broader economic conditions, personal employment setbacks affect expungement probability.

We find, on the one hand, that being employed is a very strong positive predictor of expungement receipt in a particular quarter, increasing the odds by a factor of $\mathrm{I} .77$ (Column 4). On the other hand, a recent wage loss is an even stronger predictor, increasing the odds of expungement receipt by a factor of 2.27 (Column 5). Although these results are in tension with each other, they each have plausible explanations: employed people may generally be more likely to have the resources, information, and money to pursue an expungement; but people who have experienced a recent employment setback may have more motivation to pursue a new job. These results also help to inform our interpretation of the wage and employment effects of expungement that we estimate below; we refer back to these uptake findings in Part IV.

\section{What Explains the Uptake Gap?}

Given the many life disadvantages that come with a criminal record, one might expect that most people who have records would jump at the chance to leave their record behind. Yet strikingly few do so. Why? Our quantitative data shed some light on this question but cannot really answer it. To complement our data analysis, we sought out the insights of experienced Michigan expungement lawyers and other advocates for people with records, many of whom are actively involved with outreach efforts (such as "expungement fairs") that aim to encourage and facilitate expungement applications. ${ }^{166}$ We asked them for their perceptions of

166 See Telephone Interview with Anonymous Legal Aid Lawyer (Feb. 22, 2019); Telephone Interview with Miriam Aukerman, Senior Staff Attorney, ACLU of Mich. (Feb. I6, 20I9); Telephone 
the underlying mechanisms of limited uptake. Our discussions consistently pointed to a set of likely explanations.

I. Lack of Information. - Every advocate we spoke to mentioned this concern, and many thought it was the single most important uptake barrier. Most people with records, even if they are eligible, lack the information they need to pursue an expungement. As Tracey Brame, who runs a law clinic that handles expungement cases, explained: "A lot of people have absolutely no idea that they can do this." 167 Many do not know that the expungement law exists at all. Others may have a vague idea that expungement is possible, but they do not know that they are eligible or they are unfamiliar with what they need to do to pursue one (or how to find out). Expungement law is complicated and not easy for a layperson to grasp. ${ }^{168}$ Many people do not understand their own criminal records - for example, they may not know that their decision to plead guilty to a traffic offense produced a criminal conviction. Several advocates recounted running expungement fairs in which, even though promotional materials identify the key eligibility requirements, a substantial majority of those who turn up learn sometime after they arrive that they are ineligible and walk out exasperated. It is certainly plausible that there are just as many people who are eligible who assume they are not. After all, the great majority of people with records are ineligible for expungement, and in communities where many people have records, to the extent that people know about expungement at all, frustration with its stringent restrictions is common. ${ }^{169}$ The shared impression that "nobody is eligible" may be entrenched, including among those who are actually eligible.

2. Administrative Hassle and Time Constraints. - Obtaining an expungement requires a nontrivial amount of organization, effort, and time. The process is drawn out and requires patience and ongoing resolve. A would-be applicant, after overcoming the basic informational hurdles we describe above, must track down the official application form, which is available on the website of the State Court

\footnotetext{
Interview with Tracey Brame, supra note I45; Email from Josh Hoe, Co-Chair, Policy and Educ. Comm., Nation Outside, to Sonja Starr, Professor of Law, Univ. of Mich. Law Sch. (Feb. I3, 2019 , I 2:25 PM) (on file with authors); Telephone Interview with Michael Kiehne, supra note I6 I; Telephone Interview with Chioke Mose-Telesford, supra note I6 I; Email from John Shea, Private Practitioner, to Sonja Starr, Professor of Law, Univ. of Mich. Law Sch. (Feb. I5, 2019, I:33 PM) (on file with authors); Email from Kim Thomas, supra note I33.

167 Telephone Interview with Tracey Brame, supra note I45.

168 This is particularly so given that the target population includes many people with significant socioeconomic challenges, including limited literacy. Telephone Interview with Michael Kiehne, supra note $\mathrm{I} 6 \mathrm{I}$.

169 See Email from Josh Hoe, supra note i66; Telephone Interview with Chioke Mose-Telesford, supra note I6I.
} 
Administrative Office. ${ }^{170}$ Occupying two-thirds of the second page of that form, in fairly small font, is the following set of instructions:

I. Determine whether you are eligible to apply to have your conviction set aside according to MCL $780.62 \mathrm{I}$. You must complete a separate application for each conviction if you are applying to have more than one conviction set aside [as is allowed under the current statute].

2. Find out the exact date of conviction and the charge from the court. Get a certified copy of the adjudication and attach it to your application.

3. Swear to the truth of the statements in this application and then sign it in the presence of the court clerk or a notary public.

4. Make four copies of all attachments and this application. Take all copies to the court clerk.

5. Depending on local practice, the clerk of the court may set a hearing date at the time of filing. If a hearing date is set at the time of filing, the clerk of the court will complete the Notice of Hearing.

6. Go to the local law enforcement agency for a fingerprint card and get fingerprinted on the applicant card (RI-8) . . . .

7. Make out a money order or check to the State of Michigan for the application. ... .

8. Mail a copy of the application packet, application fee, and the fingerprint card to the Michigan State Police .... .

9. Mail a copy of the application packet to the Attorney General of the State of Michigan ....

Io. Mail a copy of the application packet to the correct prosecuting official where the conviction occurred (county, city, or township) . . . .

I I. On both copies of the application, fill in the Proof of Service on the back of the form. After you fill out and sign the Proof of Service, mail or take one of the remaining application packets with the completed Proof of Service to the court. Keep the other copy for your records . . . ${ }^{171}$

It is easy to see how this list would be daunting and confusing to potential applicants (and these steps do not end the process; a court hearing follows, usually many weeks later). ${ }^{172}$ Advocates confirm that this is so; everyone we interviewed independently mentioned the administrative burdens facing applicants. As many elaborated, people with records are usually struggling with a variety of life challenges. Taking time away from work and childcare responsibilities to go to a police

170 See Mich. Courts, MC 227: Application to Set Aside Conviction, https://courts.michigan.gov/Administration/SCAO/Forms/courtforms/mc2 2 7.pdf [https://perma.cc/EYV6-YJVF].

171 Id.

172 See id.; Common Questions About Setting Aside Adult Convictions (Expungements), MICH. LEGAL HELP, https://michiganlegalhelp.org/self-help-tools/crime-traffic-and-id/commonquestions-about-setting-aside-adult-convictions-expungements [https://perma.cc/HYR8-9SB6] (stating that it can take about six months or more for a conviction to be expunged). 
station to be fingerprinted, to make several trips to a courthouse, to find a notary, and to mail all these materials to the right addresses may be simply impossible, or at least difficult enough to be strongly discouraging. ${ }^{173}$ This is especially so when prospective applicants do not live near the court that convicted them, where their expungements must be processed and the hearing must take place. And, finally, one experienced expungement lawyer at a public interest organization pointed out that many of her clients are already overwhelmed with paperwork, such as the forms associated with receiving public benefits. ${ }^{174}$

3. Fees and Costs. - Every expert we interviewed emphasized the barriers erected by fees and other associated costs. The $\$ 50$ expungement application fee cannot be waived, and it is not the only expense. ${ }^{175}$ Michael Kiehne of Michigan Legal Help and Michigan Works estimated that the total cost amounts to close to $\$$ Ioo, including fingerprinting (\$10-\$20 at most local police stations), notary fees (up to \$IO), obtaining a certified record of a conviction (\$IO-\$I 2 if it is only one page), and photocopies. ${ }^{176}$ This does not include the costs of transportation and possible loss of wages for time taken off work; Chioke Mose-Telesford of Detroit's Project Clean Slate emphasized that especially in a city with poor public transit and low car ownership, the absence of transportation options is a serious hurdle. ${ }^{177}$ For applicants living in poverty, these accumulated expenses are a serious financial impediment — consistent with our finding that the unemployed are less likely to apply. In principle, one could see the cost as an investment in future earnings; in Part IV, we document average expected gains that would very quickly cover the cost. But those without cash on hand may not have the liquidity or ability to make such an investment or may be reluctant to do so when the long-term benefits are speculative.

4. Distrust and Fear of the Criminal Justice System. - For many potential expungement applicants, their prior experience with the criminal justice system may well have been among the worst experiences of their lives. According to several advocates, this often amplifies the daunting nature of the expungement process; individuals with records, at least five years removed from an earlier criminal justice ordeal, may

173 This is consistent with the larger access-to-justice literature. The use of procedures that require travel to courthouses, for instance, can dramatically reduce participation. See Maximilian A. Bulinski \& J.J. Prescott, Online Case Resolution Systems: Enhancing Access, Fairness, Accuracy, and Efficiency, 2 I MICH. J. RACE \& L. 205, 2 I 7-35 (20I6); Prescott, supra note I36, at 38.

174 Telephone Interview with Anonymous Legal Aid Lawyer, supra note I66.

175 See Mich. CourTs, supra note I 70 (calling the \$50 fee a "required fee"); I Need a Fee Waiver for Court, MiCH. LEGAL HELP, https://michiganlegalhelp.org/self-help-tools/going-court/i-needfee-waiver-court [https://perma.cc/ $/ \mathrm{PCC}_{3}-\mathrm{FBK}_{5}$ ] (not listing an expungement application fee as a court fee that may be waived).

176 Telephone Interview with Michael Kiehne, supra note i6r.

177 Telephone Interview with Chioke Mose-Telesford, supra note i6 г. 
be strongly averse to returning to court or to a police station for any reason. ${ }^{178}$ This may be especially so if they expect the prosecutor or a crime victim to come to court to contest an expungement petition, which the law allows (and which sometimes happens). ${ }^{179}$ In addition to fear of the process itself, potential applicants may be pessimistic about the likely outcome, even though most expungement applications are in fact granted. As Kiehne explained:

Expungements are discretionary, and when you let people know that, they tend to be pessimistic. We always try to tell people that many judges are excited to grant these .... [But some] fear that it won't work [for] them an issue based on their past experience with the courts... . [S]o it is hard to get this information through. ${ }^{180}$

A potential applicant who fears that any request for an expungement will be denied may be particularly reluctant to undertake the effort, cost, and stress of pursuing record-clearing opportunities. ${ }^{181}$

5. Lack of Access to Counsel. - Some of the obstacles above could be overcome or rendered less discouraging with legal assistance. Although expungement applications can be filed pro se, the process is far less difficult to navigate for an experienced attorney. ${ }^{182}$ Yet, too often, none are available. Criminal defense lawyers are typically long since out of touch with their former clients by the time they become eligible for expungement, and most of the time defense lawyers do not advise their clients

178 See Email from Josh Hoe, supra note I66 ("Many formerly incarcerated and impacted people have very little faith in judges, so there is also a suspicion of wasting their time going through the process."); Telephone Interview with Michael Kiehne, supra note I6 . Alternatively, this fear and apprehension may take the form of a stigma "friction." Bhargava \& Manoli, supra note I38, at 3490, 3505, 35I2; see also DAVID RIBAR, IZA WORLD OF LABOR, HOW TO IMPROVE PARTICIPATION IN SOCIAL ASSISTANCE PROGRAMS 6 (20I4), https://wol.iza.org/uploads/ articles/ı04/pdfs/how-to-improve-participation-in-social-assistance-programs.pdf [https://perma.cc/ 8APE-76MQ]; Jana Friedrichsen \& Renke Schmacker, Fear of Stigmatization Prevents Individuals from Claiming Benefits, 9 DIW WEEKLY REPORT 2 I5, 2 I9 (2019); Robert Moffitt, An Economic Model of Welfare Stigma, 73 AM. ECON. REV. I023, I024-27 (I983); David C. Ribar \& Lauren A. Haldeman, Changes in Meal Participation, Attendance, and Test Scores Associated with the Availability of Universal Free School Breakfasts, 87 SOC. SERV. REV. 354, 38I (20I3).

179 See MICH. COMP. LAWS $§ 780.62$ I(I I) (2019) ("[A]n opportunity shall be given to the attorney general and to the prosecuting attorney to contest the [expungement] application ... [and] [t]he victim has the right to appear at any proceeding under this act concerning that conviction and to make a written or oral statement.").

180 Telephone Interview with Michael Kiehne, supra note I6 I.

181 A small survey of recipients of record clearance in California described respondents' past encounters with the court system as "consistently fraught with fear and shame." Adams et al., supra note 95 , at 42. Notably, when respondents did go through with clearing their record, their experiences were ultimately far more positive. See id. (noting that, given their past bad experiences, respondents were often surprised by the respect they received from judges and district attorneys during the clearance process).

182 See, e.g., Margaret (Peggy) Stevenson, Expungement: A Gateway to Work, CLEARINGHOUSE Community, Mar. 20I5, at I, I-2 ("Clearing a record without an attorney is frequently difficult. The absence of sufficient free legal help and the inability to pay for private attorneys mean that many low-income people unnecessarily carry the burden of an expungeable conviction for years."). 
about the possible prospect of an expungement five years in advance, either. Paid attorneys are out of reach for most people with records. ${ }^{183}$ And legal aid or pro bono attorneys with time on their hands are too rare. Although there have been some recent improvements on this front (which we discuss below), one legal aid lawyer with extensive expungement experience explained to us that many legal aid organizations are simply overwhelmed with the many other needs they are asked to serve, which makes it "hard to ask them to take on a whole new area." 184

6. Insufficient Motivation to Pursue Expungement. - Notwithstanding the various hardships that tend to be associated with having a criminal record, not everybody with a record is affected by it in the same way. Virtually everyone with a criminal record would presumably prefer not to have it, but not everybody necessarily experiences the record as a burden sufficient to motivate them to take on the investment of time, money, and energy that an expungement demands. This may be especially true for people with minor convictions - a theory supported by our finding that those with misdemeanors are less than half as likely to obtain expungements as those with felonies are. It seems implausible that judges would on average be less willing to grant expungements for misdemeanors, so the only credible explanation is that people with misdemeanors are less likely to apply. This is intuitively sensible. While misdemeanor records can certainly have nontrivial consequences, ${ }^{185}$ many collateral legal consequences apply only to felonies, ${ }^{186}$ and some employment applications ask about only felony records. ${ }^{187}$ It is not surprising that those with felony records appear to be particularly motivated to pursue expungement relief. In addition, motivation may affect the timing of expungements; as Tracey Brame explained: "A lot of people don't prioritize it until [the conviction] is a problem," such as when they are trying to pursue an occupational license. ${ }^{188}$

$$
* * *
$$

Our exchanges with practitioners and policymakers, who were contemplating record clearing specifically when sharing their views with us, produce a set of concrete reasons for low uptake. But record-clearing

183 See, e.g., Margaret Colgate Love, The Debt that Can Never Be Repaid: A Report Card on the Collateral Consequences of Conviction, CRIM. JUST., Fall 2006, at I6, 22 (" $[\mathrm{I}] \mathrm{t}$ is generally more expensive for a criminal offender to hire a lawyer to go to court to seek expungement, than it is to file an application for pardon ....").

184 Telephone Interview with Anonymous Legal Aid Lawyer, supra note I66.

185 See, e.g., Charlie Gerstein \& J.J. Prescott, Process Costs and Police Discretion, I 28 HARV. L. REv. F. 268, 276, 278 (2015); Issa Kohler-Hausmann, Misdemeanor Justice: Control Without Conviction, I I 9 AM. J. SOC. 35 I, 369-73 (2013).

186 See UMEZ \& PIRIUS, supra note 46 , at 3.

187 See Agan \& Starr, Ban the Box, supra note 39, at I93 n.2 ("Job application questions about records are overwhelmingly limited to convictions (not arrests), and usually to felonies.”).

188 Telephone Interview with Tracey Brame, supra note 145. 
policies - including the common requirement that eligible individuals file a petition - are embedded in a larger criminal justice context, one rife with access-to-justice and punishment disparities along economic and racial dimensions. ${ }^{189}$ To those familiar with that context, the uptake gap, while stark, may actually be unsurprising. The gap aligns with Sarah Brayne's finding that people involved in the criminal justice system are more likely to engage in "system avoidance" by self-selecting away from institutions that keep formal records or carry the mantle of government because they fear the prospect of adverse state surveillance. ${ }^{190}$ The burdens of seemingly unrelated policies, therefore, may help us understand the failure of uptake with respect to expungement.

Nevertheless, addressing the immediate barriers to uptake we describe above is critical, and various organizations have taken important steps to improve matters. Over the past fifteen years, as the challenges facing people with records have drawn more attention nationally and in Michigan, ${ }^{191}$ significant efforts in Michigan to increase support for people seeking expungement have sprouted. The City of Detroit, for example, recently adopted an initiative called Project Clean Slate to support expungement activity, ${ }^{192}$ and Michigan Works, a statewide workforce development program, has become increasingly involved in the issue. ${ }^{193}$ Michigan Legal Help, a nonprofit that provides do-it-yourself tools to pro se litigants, has developed an online tool that allows applicants to assess their eligibility and to fill out the application form, although they must still go through the various steps to file it. ${ }^{194}$

Many of these organizations have sponsored expungement fairs, which have become perhaps the central outreach tool in this space. ${ }^{195}$

189 See David J. HARding ET AL., ON The OUtSide: Prisoner ReEntry AND REINTEGRATION 4-5 (20I9) (acknowledging "a broader cultural, political, and institutional shift toward order, control, and the use of punishment to solve social problems, particularly those associated with poverty or ethnoracial minorities").

190 Sarah Brayne, Surveillance and System Avoidance: Criminal Justice Contact and Institutional Attachment, 79 AM. SOC. REV. 367, 385 (2014).

191 We discuss recent expansions in expungement law above, supra notes I 2-2 I and accompanying text. While the past couple of years have been particularly active, the trend of expansion actually goes back further. See Brian M. Murray, A New Era for Expungement Law Reform? Recent Developments at the State and Federal Levels, ro HARV. L. \& POL'y REV. 361, 369-73 (2016) (discussing reforms between 2009 and 2015).

192 See Project Clean Slate, CITY OF DETROIT, https://detroitmi.gov/departments/lawdepartment/project-clean-slate [https://perma.cc/ZJQ2-E 4 LY].

193 See Have You Been Convicted of a Crime?, MICH. WORKs! SE., https://www.mwse.org/ expungement [https://perma.cc/U $\mathrm{U}_{4} \mathrm{~B}_{7}$-SJCW]; Telephone Interview with Chioke Mose-Telesford, supra note I6I.

194 See Do-It-Yourself Expungement (Adult Conviction), Мich. LEgal HeLP, https:// michiganlegalhelp.org/self-help-tools/crime-traffic-and-id/do-it-yourself-expungement-adult-conviction

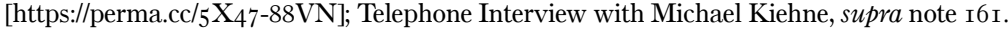

195 See Michigan Works! Southeast Expungement Fair, Mich. Legal HelP, https:// michiganlegalhelp.org/node/II324 [https://perma.cc/CUR6-MEQ5]; Project Clean Slate Fair This 
Expungement fairs are designed at a minimum to provide information, and many also provide concrete assistance: applicants have been encouraged to fill out applications on site, and some fairs have had sheriffs present to do the fingerprinting, as well as notaries. ${ }^{196}$ Depending on the sponsoring organization's funding, these fairs have sometimes been able to defray the costs for applicants - for example, by offering fingerprinting for free or paying for the certified record of conviction. ${ }^{197}$ Expungement fairs in Detroit have reportedly been quite large, some perhaps close to a thousand participants, although most attendees have proven to be ineligible. ${ }^{198}$ Fairs elsewhere in the state have generally not had anywhere close to this kind of attendance. ${ }^{199}$

Miriam Aukerman, who worked on expungement cases at Western Michigan Legal Aid until 2010, told us:

When I started doing this work back in 2003 or 2004 , nobody was doing it.

People didn't think it was important. When I left in 2010 , it was a thing.

Legal services offices had started doing it; there were self-help packets avail-

able .... Expungement fairs were starting to happen. Advocacy organi-

zations started spreading the word. ${ }^{200}$

Aukerman's recollection is borne out by data. In 2010, the last full year for which we have complete data, the number of known-date expungements granted in Michigan was 2044, which is $67 \%$ higher than the number in 2004 (I224). MSP reported to us that 2594 expungements were granted in 20I7; this number (although down slightly from 20I6)

Saturday to Provide Free Criminal Record Expungement for Detroiters, CITY OF DETROIT, https:// detroitmi.gov/news/project-clean-slate-fair-saturday-provide-free-criminal-record-expungement-

detroiters [https://perma.cc/P97 U-43 YU]; Telephone Interview with Michael Kiehne, supra note I6r; Telephone Interview with Chioke Mose-Telesford, supra note I6r.

196 See, e.g., Hunter McLaren, Expungement Fair Gives Jackson Residents Second Chance at Finding Work, Housing, MLive (Aug. IO, 20I9), https://www.mlive.com/news/jackson/2019/08/ expungement-fair-gives-jackson-residents-second-chance-at-finding-work-housing.html [https:// perma.cc/LR6G-SFR 5 ] (describing the provision of reduced fees and a local police officer to facilitate the expungement application process).

197 See id.

198 See Telephone Interview with Michael Kiehne, supra note I6I (indicating that some Detroit fairs have had approximately 1000 attendees); Attorneys Participate in "Know Your Rights" Program, Expungement Fair, LEGALNEwS.COM (Feb. Iо, 2020), http://legalnews.com/ detroit/I484605 [https://perma.cc/725R-DJQB]; Corey Williams, Detroit Jobseekers Look to Have Nonviolent Records Expunged, Associated PREss, June 4, 2016; see also Project Clean Slate Fair This Saturday to Provide Free Criminal Record Expungement for Detroiters, supra note 195 (noting that only 200 Detroit residents had records expunged that year).

199 See, e.g., Gabriella Galloway, Some with Criminal Records Get a Possible Second Chance, 9 \& Io News (July 29, 20I9), https://www.gand Ionews.com/2019/o7/29/some-with-criminal-records-get-apossible-second-chance [https://perma.cc/UC8M-DYA3]; McLaren, supra note I96. But see, e.g., Jacqueline Francis, Criminal Expungement Fair Draws Hundreds, WoODTV.COM (Oct. 2, 20I9, I I:I 2 $\mathrm{PM}$ ), https://www.woodtv.com/news/grand-rapids/criminal-expungement-fair-draws-hundreds [https: //perma.cc/VP6M-XRBJ] (describing a fairly large Grand Rapids fair with 435 attendees).

200 Telephone Interview with Miriam Aukerman, supra note I66. 
represents another $27 \%$ growth since 2010.201 These changes suggest that efforts to help people surmount the various barriers to access expungement opportunities can successfully encourage applications.

That said, one should not be too sanguine; even if uptake doubled from what we measure (for five-year periods ending between 2009 and 20 II), it would still be only I3\%. Expungement lawyers articulated to us the frustration that many of their clients feel with the process, even with legal help. ${ }^{202}$ Rather than expect a massive influx of aid to help people navigate the process, we should recognize that substantially closing the uptake gap will require legal changes to simplify that process. We return to this point in the Conclusion.

Finally, it bears noting that, although our interviews focused mainly on the problem of low uptake among eligible individuals, every advocate we spoke to also stressed the stringency of the eligibility requirements, which in each of their views exclude a great many worthy candidates. ${ }^{203}$ Reforms in 20II and 2015 slightly softened the requirements regarding the allowable number of convictions, ${ }^{204}$ but they are still strict and in many ways quite arbitrary. Today, in Michigan, anyone with two felony convictions is still excluded, even if they are low-level felonies and even if they are two counts arising from the same incident. ${ }^{205}$ Inexplicably, people with three misdemeanors cannot seek expungements at all, even though people with one felony plus two misdemeanors can seek to expunge the felony. ${ }^{206}$ Traffic misdemeanors cannot be expunged themselves but nevertheless count toward the limit and thus may disqualify an individual from expunging another conviction. ${ }^{207}$ These offenses are very common in Michigan, accounting for more than half of all misdemeanor

201 Email from Ted Kilvington, supra note I 25.

202 See Telephone Interview with Miriam Aukerman, supra note r66; Email from Josh Hoe, supra note 166 .

203 See, e.g., Telephone Interview with Anonymous Legal Aid Lawyer, supra note i66; Telephone Interview with Miriam Aukerman, supra note I66 ("90\% of the people would walk out [of an expungement fair] and be angry after you explained that you could only have one conviction [to be eligible]. . . . It could be that the people who are most impacted by criminal records are those who are not eligible."); Email from Josh Hoe, supra note i66 ("A large number of folks are made ineligible for expungement by either carve-outs in the legislation or by the fact that it only applies to people with I felony and/or 2 misdemeanors.").

204 See MICH. COMP. LAWS $\$ 780.62$ I(4) (2020) (effective Jan. I 2, 20I5) (expanding eligibility for expungement to victims of human trafficking); id. $\$ 780.62 \mathrm{I}(\mathrm{I})$ (c) (2020) (effective June 23, 20II) (expanding eligibility for expungement of an offense to individuals who have two other "minor offense[s]").

205 See id. $\$ 780.62$ I(I)(a) (2020) (effective Jan. I 2, 20I5) (stating that individuals are only eligible for an expungement if they "[have been] convicted of not more than [one] felony offense").

206 See id. $\S 780.62$ I(I)(a)-(b). This seems like a clear drafting error, but it is apparently enforced. Telephone Interview with Michael Kiehne, supra note I6 I.

207 See MicH. COMP. LAWS $\$ 780.62 \mathrm{I}(3)(\mathrm{d})$ (2020) (stating that expungements shall not be granted for traffic offenses). 
convictions. ${ }^{208}$ Petty misdemeanors, including violations of hunting and fishing laws and dog-leash laws, likewise count toward the limit. ${ }^{209}$ In addition, the waiting period now runs five years from the completion of all components of the sentence, which means that people with lengthy probation or parole terms might actually have to wait out eight or ten recidivism-free years in the community, not just five years as was required under Michigan's old law. ${ }^{210}$

All of these restrictions mean that the low uptake rate we estimate is even starker when viewed in context: it is a very small fraction of a very small fraction. For the past decade about 2000 expungements per year have been granted in Michigan. Meanwhile, each year the Michigan state courts add about 300,000 new criminal convictions. ${ }^{211}$ On balance, the population of people living with criminal records is continuing to grow quickly; the existing expungement regime is like a bucket removing water from an ever-rising ocean. ${ }^{212}$

\section{RECIDIVISM OUTCOMES}

Petition-based expungement is not very common - but what happens when it does occur? Are there significant public-safety costs to granting record-clearing relief? For example, does expungement increase the risk of recidivism or conceal other substantial dangers from the public? Public-safety concerns underlie the most common objections to expungement laws, the idea being that the public - especially people with particular interests at stake, such as employers and landlords - have a right to know when people have criminal records because of their heightened risk of committing future crimes. ${ }^{213}$ Here, our data paint a

208 See Mich. Courts, supra note I50. An experienced Michigan expungement attorney told us that it is common for her clients to believe they are eligible for an expungement because they do not understand that a prior traffic offense happened to be a misdemeanor and because it does not come up in ICHAT, the free background check tool that some use to check their eligibility (though it does ultimately appear in the official background check to determine actual eligibility). Telephone Interview with Anonymous Legal Aid Lawyer, supra note i66.

209 See MicH. COMP. LAWS $\$ 780.62$ I(I6)(f) (2020) (stating the definition of a misdemeanor for purposes of the statute); $c f$., e.g., id. $\$ 324.43560$ (providing that a person who violates the hunting and fishing licensing rules "is guilty of a misdemeanor").

210 See id. $\$ 780.62$ I(5)(a)-(d) (effective Jan. I2, 2015).

211 See supra note I50.

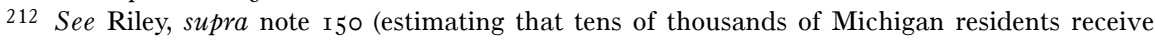
first-time felony convictions each year).

213 See Murray, supra note I9I, at 375 (describing the counterargument to expungement that "federal crimes are serious, and actors within the community should be able to obtain information about ex-offenders that might be relevant to an important decision, especially related to hiring"); see also, e.g., Doe v. United States, I Io F. Supp. 3d 448, 449, 455 (E.D.N.Y. 20I5) (memorializing the judge's belief that "employers are generally entitled to know about the past convictions of job applicants," $i d$. at 449, and indicating that, in part for that reason, expungements may be granted only when "extraordinary circumstances are present," id. at 455); U.S. DEP'T OF JUSTICE, ATtorney General's Report ON CRIMINAL History BACKGROUND ChECKS i (2006), 
sunnier picture. In section A, we estimate recidivism rates for expungement recipients, finding that reoffending is strikingly rare. In section B, we consider the interpretation and policy implications of our findings. In this discussion, we rely mainly on other criminological research for guidance; as we explain below, the nature of the law and our data make it difficult to directly assess the causal effect of receiving an expungement on criminal behavior.

\section{A. Recidivism Among Expungement Recipients}

In Table 4, we report two-year and five-year rearrest and reconviction rates for expungement recipients, starting from the date of receipt of the expungement. ${ }^{214}$ We analyze the criminal histories of the full universe of individuals receiving expungements up through the beginning of December 2010.215 Most of the data concerns we raise with regard to the "eligible" sample of individuals with records that we analyze in Part II do not arise here. ${ }^{216}$ Our only significant data limitation

https://www.bjs.gov/content/pub/pdf/ag_bgchecks_report.pdf [https://perma.cc/4BY8-WT8M] (stating that employers want access to criminal records so they can "protect employees, customers, vulnerable persons, and business assets" and avoid negligent hiring suits).

214 Recidivism rates are a complicated concept, see generally MiCHAEL D. MALTZ, RECIDIVISM (I984), and one of the important questions in constructing estimates is the length of time over which to consider an individual "at risk" of reoffending. At least within the domain of government statistics, there is no real consensus on the appropriate at-risk period. See Bill Montgomery, We Have No Standard for Measuring Recidivism, THE HILL (Nov. I5, 2017, 3:00 PM), https://thehill.com/opinion/criminal-justice/360520-we-have-no-standard-for-measuring-recidivism [https://perma.cc/ $\mathrm{C}_{5} 6 \mathrm{~V}-8 \mathrm{RN}_{7}$ ]. The two-year rates that we report are more typical of the recidivism literature, but the time period varies. See, e.g., Seena Fazel \& Achim Wolf, A Systematic Review of Criminal Recidivism Rates Worldwide: Current Difficulties and Recommendations for Best Practice, Io PLOS ONE $3-4, \quad 5 \quad$ tbl.3 (2015), https://journals.plos.org/plosone/article/ file?id=10.137 I/journal.pone.01 30390 \& type $=$ printable $[$ https://perma.cc/NJ77-2LQM]. Three-year follow-up periods are also common, but selection of the length of time for evaluating recidivism is often driven by data availability. See MARIEL AlPer ET AL., U.S. DeP'T OF Justice, 2018 UPdATE ON PRISONER RECIDIVISM: A 9-YEAR FOllOW-UP PERIOD (2005-20I4) I4 (20I8), https://www.bjs.gov/content/pub/pdf/I8uprgyfupo5 I4.pdf [https://perma.cc/YT 9 K-MAQ9]. Longer time spans are generally more beneficial for studying patterns of recidivism and their attributes. See id. We are readily able to offer a longer-term measure, too, because our data cover a more extensive span than many other researchers have been able to observe. We opt to include both twoand five-year measures to provide both points of comparison.

215 We rely for this analysis on an MSP criminal history dataset that ends on December 6, 20 I 2. To allow a sufficient follow-up period, our analysis sample accordingly includes nearly all individuals receiving expungements in Michigan with known dates up through December 6, 2010 (for the two-year rates), and December 6, 2007 (for the five-year rates). The only individuals we drop are 232 people identified in the data as having out-of-state driver's licenses, to reduce any bias that might result from unobserved out-of-state recidivism. The resulting numbers of observations for our analysis are 20,955 for the two-year sample and 15,256 for the five-year sample.

216 The rates we report are not really "estimates" for these populations; there is no sampling error in the results that we report for pre-20I I Michigan expungement recipients. We need not worry about the representativeness of the sample in thinking about how expungement recipients fared in Michigan during our study period. However, our calculations are "estimates" if we think of past expungement recipients as a "sample" that is representative of future expungement recipients (or, 
TABLE 4. REARREST AND RECONVICTION RATES FOR EXPUNGEMENT RECIPIENTS

\begin{tabular}{|c|c|c|c|c|}
\hline & $\begin{array}{c}(1) \\
\text { Two-Year } \\
\text { Arrest } \\
\text { Rate }\end{array}$ & $\begin{array}{c}(2) \\
\text { Two-Year } \\
\text { Conviction } \\
\text { Rate }\end{array}$ & $\begin{array}{c}(3) \\
\text { Five-Year } \\
\text { Arrest } \\
\text { Rate }\end{array}$ & $\begin{array}{c}\text { (4) } \\
\text { Five-Year } \\
\text { Conviction } \\
\text { Rate }\end{array}$ \\
\hline \multicolumn{5}{|l|}{ A. Full Sample } \\
\hline 1. Overall Rearrest/Reconviction Rates & $\begin{array}{c}3.4 \% \\
(0.13 \%)\end{array}$ & $\begin{array}{c}1.8 \% \\
(0.09 \%)\end{array}$ & $\begin{array}{c}7.1 \% \\
(0.21 \%)\end{array}$ & $\begin{array}{c}4.2 \% \\
(0.16 \%)\end{array}$ \\
\hline 2. Violent Rearrest/Reconviction Rates & $\begin{array}{c}1.0 \% \\
(0.07 \%)\end{array}$ & $\begin{array}{c}0.2 \% \\
(0.03 \%)\end{array}$ & $\begin{array}{c}2.6 \% \\
(0.13 \%)\end{array}$ & $\begin{array}{c}0.6 \% \\
(0.06 \%)\end{array}$ \\
\hline 3. Felony Rearrest/Reconviction Rates & $\begin{array}{c}1.2 \% \\
(0.07 \%)\end{array}$ & $\begin{array}{c}0.3 \% \\
(0.04 \%)\end{array}$ & $\begin{array}{c}2.7 \% \\
(0.13 \%)\end{array}$ & $\begin{array}{c}1.0 \% \\
(0.08 \%)\end{array}$ \\
\hline $\begin{array}{l}\text { Number of Observations } \\
\text { B. Subsamples }\end{array}$ & 20,955 & 20,955 & 15,256 & 15,256 \\
\hline 1. Expungement After $<6$ Years & $\begin{array}{c}3.8 \% \\
(0.30 \%)\end{array}$ & $\begin{array}{c}2.1 \% \\
(0.23 \%)\end{array}$ & $\begin{array}{c}8.1 \% \\
(0.49 \%)\end{array}$ & $\begin{array}{c}4.9 \% \\
(0.39 \%)\end{array}$ \\
\hline 2. Expungement in Years 11 and 12 & $\begin{array}{c}2.8 \% \\
(0.50 \%)\end{array}$ & $\begin{array}{c}1.6 \% \\
(0.37 \%)\end{array}$ & $\begin{array}{c}6.3 \% \\
(0.86 \%)\end{array}$ & $\begin{array}{c}3.6 \% \\
(0.66 \%)\end{array}$ \\
\hline 3. Expunged Offense: Felony & $\begin{array}{c}4.0 \% \\
(0.20 \%)\end{array}$ & $\begin{array}{c}1.9 \% \\
(0.14 \%)\end{array}$ & $\begin{array}{c}8.1 \% \\
(0.33 \%)\end{array}$ & $\begin{array}{c}4.6 \% \\
(0.26 \%)\end{array}$ \\
\hline 4. Expunged Offense: Misdemeanor & $\begin{array}{c}3.1 \% \\
(0.17 \%)\end{array}$ & $\begin{array}{c}1.8 \% \\
(0.13 \%)\end{array}$ & $\begin{array}{c}6.4 \% \\
(0.28 \%)\end{array}$ & $\begin{array}{c}3.8 \% \\
(0.22 \%)\end{array}$ \\
\hline 5. Expunged Offense: Incarcerated & $\begin{array}{c}3.2 \% \\
(0.23 \%)\end{array}$ & $\begin{array}{c}1.7 \% \\
(0.17 \%)\end{array}$ & $\begin{array}{c}6.7 \% \\
(0.38 \%)\end{array}$ & $\begin{array}{c}3.9 \% \\
(0.29 \%)\end{array}$ \\
\hline 6. Expunged Offense: Not Incarcerated & $\begin{array}{c}3.5 \% \\
(0.15 \%)\end{array}$ & $\begin{array}{c}1.8 \% \\
(0.11 \%)\end{array}$ & $\begin{array}{c}7.2 \% \\
(0.25 \%)\end{array}$ & $\begin{array}{c}4.3 \% \\
(0.19 \%)\end{array}$ \\
\hline 7. Expunged Offense: Violent & $\begin{array}{c}4.4 \% \\
(0.37 \%)\end{array}$ & $\begin{array}{c}2.2 \% \\
(0.27 \%)\end{array}$ & $\begin{array}{c}8.4 \% \\
(0.62 \%)\end{array}$ & $\begin{array}{c}4.4 \% \\
(0.46 \%)\end{array}$ \\
\hline $\begin{array}{l}\text { 8. Expunged Offense: Violent } \\
\text { (violent rearrest/reconviction only) }\end{array}$ & $\begin{array}{c}1.6 \% \\
(0.23 \%)\end{array}$ & $\begin{array}{c}0.3 \% \\
(0.10 \%)\end{array}$ & $\begin{array}{c}4.0 \% \\
(0.44 \%)\end{array}$ & $\begin{array}{c}0.8 \% \\
(0.20 \%)\end{array}$ \\
\hline
\end{tabular}

Notes: Rearrest and reconviction data come from Michigan State Police criminal history files. The full sample consists of all individuals with no record of an out-of-state driver's license who receive a known-date expungement in Michigan through December 6, 2010, for two-year rates and through December 6, 2007, for five-year rates. In Panel B, all rearrest and reconviction rates are "overall" rates - that is, they count any new criminal arrest or conviction - except for Row 8 , which shows only the rearrest and reconviction rates for violent offenses. Standard errors are reported in parentheses.

Subsample sizes are available from the authors upon request.

potentially, expungement recipients from other jurisdictions) about whom we wish to make predictions. Accordingly, we include standard errors in Table 4, in parentheses; these show that our estimates (if understood as such) are in any event quite precise. 
is our inability to observe out-of-state and federal arrests and convictions, ${ }^{217}$ which may mean that we slightly underestimate true recidivism rates. We do not believe this omission has a large effect, however, for reasons we already discuss in detail in Part II: federal arrests and convictions are rare, and interstate moves and interstate travel to commit crimes are not common either. ${ }^{218}$

In Row I of Table 4, Panel A, we report the overall two-year and five-year rearrest and reconviction rates, while in the remaining rows we give specific rates for certain types of crime that may be of particular public and policy concern: violent offenses and felony offenses. ${ }^{219}$ All of these rates show a consistent pattern: recidivism among expungement recipients is low. ${ }^{220}$ Overall, $3.4 \%$ are rearrested and $1.8 \%$ are reconvicted for crimes within two years; $7.1 \%$ are rearrested and $4.2 \%$ are reconvicted within five years. The numbers are even lower when we focus specifically on the types of crimes that worry people most. For example, within five years, only $2.6 \%$ of expungement recipients are

217 See supra notes I47-I50 and accompanying text.

218 Applying the assumptions we use in Part II that I.8\% of individuals move per year and $4 \%$ of crime is committed across state borders, we expect we might be missing about $5-6 \%$ of the rearrests and reconvictions for our two-year outcome period and perhaps $7-8 \%$ in the five-year period (when people have had more time to move). See supra notes I47-I50 and accompanying text. Given the very low recidivism rates we report in Table 4 , the effect of this problem is negligible in percentage-point terms. Another useful source is a 2005 study from the Bureau of Justice Statistics, which finds nontrivial rates of out-of-state recidivism over the course of five years (whether due to cross-border crime or individuals changing their state of residence). See MATTHEW R. DUROSE ET AL., U.S. DEP'T OF JUSTICE, RECIDIVISM OF PRISONERS RELEASED IN 30 STATES IN 2005: PATTERNS FROM 2005 TO 20IO, at 7 (20I4), https://www.bjs.gov/content/pub/pdf/rprtso5po5 IO. pdf [https://perma.cc/J2 BP-WTKN]. But still, even that out-of-state recidivism rate (I0.9\%) is only about one-seventh of the overall recidivism rate $(75.4 \%)$ observed over the same period. Id. at $7-$ 8. If we were to apply that same ratio here, our estimated recidivism rates would understate the true rate by much less than a percentage point. Moreover, Michigan residents almost surely engage in fewer cross-border crimes than residents in many states, simply because Michigan is surrounded on most sides by water and has no interstate metropolitan areas.

219 Felonies are identified as such in the MSP records we use in our analysis; we classify an offense as violent if it involves the use or threat of force according to its statutory definition. Statutorily, a felony in Michigan is defined as an offense for which a person convicted of the charge may be punished by death or imprisonment. See MICH. COMP. LAWS $\S 750.7$ (2020). Violent offenses are a subset of both felonies and misdemeanors.

220 Recidivism risk varies by type of initial crime, age, poverty, and many other factors, but in general, recidivism rates below Io\% are relatively low. For example, in a recent multistate study of prisoners released in 2005 , over $60 \%$ are rearrested within two years, and $77 \%$ are rearrested within five years. See AlPER ET AL., supra note 2 I4, at I I tbl.7. Limiting this to in-state arrests (to more closely match our data), these numbers are $54.4 \%$ and $66.1 \%$, respectively. See id. at 4 tbl.2. Recidivism rates for individuals on probation are also much higher. See PATRICK A LANGAN \& MARK A. CUNNIFF, U.S. DEP'T OF JUSTICE, RECIDIVISM OF FELONS ON PROBATION, I986-89, at 5-6 (I992), https:/www.bjs.gov/content/pub/pdf/rfp8689.pdf [https:// perma.cc/7 BAU-4J4 $\mathrm{J}_{4} \mathrm{~F}$; see also Dana Goldstein, The Misleading Math of "Recidivism," MARSHALL PROJECT (Dec. 4, 20I4, I I:I5 AM), https://www.themarshallproject.org/20I4/I 2/O4/ the-misleading-math-of-recidivism [https://perma.cc/UAS7-BS2 Q]. 
rearrested and $0.6 \%$ are reconvicted for violent crimes; $2.7 \%$ are rearrested and $\mathrm{I} \%$ are reconvicted for felonies.

We emphasize that these rates are much lower than those found in most studies of criminal recidivism. ${ }^{221}$ Indeed, our statistics suggest that expungement recipients pose a lower crime risk than the general population of Michigan as a whole. Although no general-population data are available that directly parallel the figures in Table 4, the state does report annual arrest figures. For comparison purposes, in the two-year period from 2009-10, Michigan police made about 6.6 arrests per Ioo adults in the population. ${ }^{222}$ In contrast, using cases from approximately the same time period, we calculate only 4.7 arrests per Ioo expungement recipients within two years of their having received an expungement. ${ }^{223}$ This comparison is particularly striking given that expungement recipients (like people with criminal records generally) tend to have other

221 See, e.g., Donald P. Green \& Daniel Winik, Using Random Judge Assignments to Estimate the Effects of Incarceration and Probation on Recidivism Among Drug Offenders, 48 CRIMINOLOGY 357, 370 (2010); Ilyana Kuziemko, How Should Inmates Be Released from Prison? An Assessment of Parole Versus Fixed-Sentence Regimes, I28 Q.J. ECON. 37I, 385-86 (20I3); Cody Tuttle, Snapping Back: Food Stamps Ban and Criminal Recidivism, I I AM. ECON. J.: ECON. POL'Y 30I, 3 I5-I6 (2019). For sources specific to Michigan, see, for example, David J. Harding et al., Shortand Long-Term Effects of Imprisonment on Future Felony Convictions and Prison Admissions, I I 4 PNAS, II,IO3, I I,I06-O7 (2017); Chris Gautz, Michigan Recidivism Rate Falls to Its Lowest Level at 28. I Percent, Michigan.Gov (Feb. I3, 20I8), https://www.michigan.gov/som/o,4669,7I 92-26847-459956--,oo.html [https://perma.cc/MgGJ-WKHH].

222 Arrest figures are summed across "total arrests" for persons eighteen and up in MiCH. STATE POLICE, 2009 STATE ARREST TOTALS (20I0), https:/www.michigan.gov/documents/ msp/2009Annual_StatewideArrests_332334_7.pdf [https://perma.cc/TAA9-D5XV], and MICH. StATE POlice, 20io StATEWIDE ARREST TOTALS (20I I), https:/www.michigan.gov/documents/ msp/2010_Annual_StatewideArrests_358704_7.pdf [https://perma.cc/5HDB-CWKA]. Population figures come from the 20 о Census. QuickFacts: Michigan, U.S. CENSUS BurEAU, https://www. census.gov/quickfacts/fact/table/MI/POPo Iо2 Io [https://perma.cc/Q7KR-UZWB].

223 We calculate this number for the cohort of those receiving criminal-record expungements between December 2006 and December 2010, running for two years from each individual's expungement date and excluding those individuals known to have out-of-state licenses; this is the most recent complete expungement-receiving cohort for which we have two years of subsequent criminal history data. Total arrests per capita over two years are higher than the two-year arrest rates for the same population (like those we report in Table 4 ) because some people are arrested more than once. See Alexi Jones \& Wendy Sawyer, Arrest, Release, Repeat: How Police and Jails Are Misused to Respond to Social Problems, PRISON POL'y InITIATIVE (Aug. 20I9), https://www.prisonpolicy.org/reports/repeatarrests.html [https://perma.cc/33J2-CV53]. There are no public data on the number of unique individuals arrested in Michigan in any given period (for the closest we can find, see Wanda Bertram \& Alexi Jones, How Many People in Your State Go to Local Jails Every Year?, PRISON POL'Y INITIATIVE (Sept. I8, 20I9), https://www.prisonpolicy. org/blog/2019/og/I8/state-jail-bookings [https://perma.cc/2L9P-PTGM]), so the number of arrests is the best metric to use for this comparison. We do not have a similarly authoritative source for the number of convictions statewide. However, we can gain some insight into individuals who are arrested multiple times from the Prison Policy Initiative: "Using nationally representative data from the National Survey on Drug Use and Health (NSDUH), we find that at least 4.9 million individuals were arrested and booked in 2017 . Of those 4.9 million individuals, 3.5 million were arrested only once in 2017; 930,000 were arrested twice; and 430,000 were arrested three or more times." Jones \& Sawyer, supra. 
characteristics that are generally associated with higher crime risk for example, they are more likely to be male and poor than the general population is. In fact, if we compare expungement recipients to subsets of the general population that look more like them in terms of observable characteristics such as age and gender, the comparison is even more favorable to expungement recipients. ${ }^{224}$

In Panel B of Table 4, we replicate the main results from Panel A, Row I (overall arrest and reconviction rates) for subsets of the expungement population of particular interest. In Row I, we examine individuals who receive their expungements early, in their first year of eligibility (that is, by the end of the sixth year since sentencing or release). The waiting period for expungements in Michigan is five years, but the actual median elapsed time before receipt is nearly ten years after sentencing or release. ${ }^{225}$ Because recidivism risk declines over time, this delay should be expected to reduce expungement recipients' recidivism rates. $^{226}$ But policymakers might understandably wonder what would happen if people did not wait those extra years - which would be the consequence of a policy that made expungements automatic after five years. ${ }^{227}$ Row I's estimate in Table 4.B is designed to inform the question whether five years is enough of a waiting period - and what we

224 These calculations are available upon request. Age and gender are two of the characteristics that most strongly predict arrest rates, so it is helpful to begin by considering their role. One might expect that expungement recipients' low recidivism risk could be explained by the fact that, by the time they qualify for an expungement, they have already "aged out" of crime. But while this may sometimes be true (and indeed there are few very young adults who obtain expungements), the overall age distribution of expungement recipients is similar to, and actually a bit younger than, the general adult population; a majority are still in their twenties and thirties, ages when arrest rates are still higher than average. See Howard N. SNyder, U.S. DeP'T OF Justice, ARrest in THE United StATES, I990-20io, at 3 (20I2), https://www.bjs.gov/content/pub/pdf/aus9oro.pdf [https://perma.cc/X6BZ-VXJ2]. Meanwhile, a majority of expungement recipients are male, see supra tbl.2, and males have higher arrest rates, see SNYDER, supra, at 2. If one reweights the general population arrest rates so as to mirror the expungement-recipient pool in terms of its age and sex distribution, the projected general-population rate becomes even higher: about 7.6 arrests per Ioo people in each two-year period (compared, again, to 4.7 for expungement recipients). General-population arrest data are not available broken down by many other characteristics, but we can be fairly certain that populations that are comparable to expungement recipients across other demographic and socioeconomic dimensions would have even higher arrest rates, since expungement recipients tend to be disadvantaged in various ways, as we explain in Part II. See supra section II.B, pp. 2493-250I.

225 See supra tbl.2.

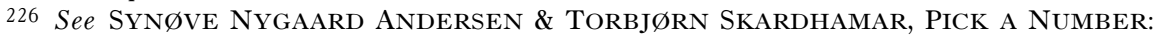
MAPPING RECIDIVISM MeAsures AND THEIR CONSEQUENCES I5-I7 (20I4), https://www.ssb.no/en/forskning/discussion-papers/_attachment/I66596 [https://perma.cc/3 UEHTGKQ]; NATHAN JAMES, CONG. REsEARCH SERV., RL 34287 , OfFEnder ReEntry: CORRECTIONAL STATISTICS, REINTEGRATION INTO THE COMMUNITY, AND RECIDIVISM 7 \& fig.3 (2014); Kuziemko, supra note 22 I, at 379; Fredrik Sivertsson, Catching Up in Crime? LongTerm Processes of Recidivism Across Gender, 2 J. DEvElopMental \& LifE-COURSE CRIMINOLOGY $37 \mathrm{I}, 376$ (20I6).

227 See, e.g., Francisco, supra note 73; Kelan Lyons, Lamont to Introduce Clean Slate Legislation in Next Session, CT MIRROR (Jan. 8, 2020), https:/ctmirror.org/2020/or/o8/lamont-to-introduce- 
find in our data suggests that it is. Recidivism rates in all columns are only very slightly higher than the main-sample numbers, indicating that this subgroup remains low risk relative to the general public.

Meanwhile, Row 2 in Table 4.B shows rearrest rates for people who receive expungements in the eleventh or twelfth year after sentencing or release - a good proxy for the effect of providing for expungements after ten clean years, as Pennsylvania's new law does automatically for minor offenses. ${ }^{228}$ These recidivism rates are even lower than average expungement-recipient rates (unsurprisingly, given the long clean records of these individuals). All in all, though, the differences among these various cohorts are quite small, suggesting that eligibility waiting-period differences might not matter very much in terms of fostering lower postexpungement recidivism rates.

In Rows 3 and 4 of Table 4 .B, we show recidivism numbers for those whose expungement conviction was a felony and a misdemeanor, respectively. Recidivism rates are low for both groups, although slightly higher for the felony group. In Rows 5 and 6 respectively, we compare the behavior of expungement recipients who did and did not serve any time behind bars, according to MSP records. One might expect recidivism rates for the formerly incarcerated to be higher for two reasons: they have more serious prior convictions, ${ }^{229}$ and they may face additional socioeconomic disadvantages arising from their period of incarceration. ${ }^{230}$ These influences might be counterbalanced by the fact that

clean-slate-legislation-in-next-session [https://perma.cc/B 75 S-85JG]; $c f$. Margaret Love \& David Schlussel, Model Law Proposes Automatic Expungement of Non-conviction Records, CRIME REP. (Dec. I8, 20I9), https://thecrimereport.org/20I9/I2/I8/model-law-proposes-automaticexpungement-of-non-conviction-records [https://perma.cc/7 $\left.\mathrm{L}_{5} \mathrm{G}-\mathrm{FPRE}\right]$.

228 See i8 Pa. CONS. Stat. § 9i22.2 (2018); see also Restoration of Rights Project, Pennsylvania Restoration of Rights \& Record Relief, Part III (2020), https:// ccresourcecenter.org/state-restoration-profiles/pennsylvania-restoration-of-rights-pardonexpungement-sealing-2 [https://perma.cc/Q9CJ-BYV6]; supra note 69 and accompanying text.

229 See Blanton v. City of North Las Vegas, 489 U.S. 538,542 (I989) ("[B]ecause incarceration is an 'intrinsically different' form of punishment, it is the most powerful indication of whether an offense is 'serious." (quoting Muniz v. Hoffman, 422 U.S. 454, 477 (I975))); NAT'L RESEARCH COUNCIL, The Growth of InCARCERATION IN THE UNiTED STATES: Exploring CAuses And Consequences ig (Jeremy Travis et al. eds., 20I4) ("Prison terms usually are reserved for those found guilty of more serious crimes, defined as felonies by state and federal legislatures."). But see S. Union Co. v. United States, 567 U.S. 343, 35 I (2012) ("But not all fines are insubstantial, and not all offenses punishable by fine are petty."); NAT'L RESEARCH COUNCIL, supra, at 86 ("Considerations of proportionality and parsimony have fallen into neglect in the United States. Many laws enacted in the I 980 os and I 990 os required less serious crimes to be punished more severely than more serious ones. Examples include mandatory minimum sentence laws requiring longer terms for people convicted of small sales of drugs than terms typically imposed for many violent offenses, and the sentencing of people to 25 -year minimum terms for property misdemeanors under California's three strikes law.").

230 See John Bronsteen et al., Happiness and Punishment, 76 U. CHI. L. REV. I037, I038 (2009) ("Even large fines are likely to have only minor effects on the well-being of those who receive them, because people adjust quite easily to their new financial circumstances.... On the other hand, 
during the five-year period in which we observe them, formerly incarcerated expungement recipients are further beyond their conviction/release dates (because the clock runs from the later of the two events) and are older on average. ${ }^{231}$ On balance, we find very slightly lower recidivism rates for those who have been incarcerated.

Finally, in Rows 7 and 8 of Table 4.B, we present recidivism numbers for people who have had violent-offense convictions expunged. In Row 7 , we demonstrate that the overall rearrest and reconviction numbers for this subsample are slightly higher than the average for the entire sample, although still quite low. In Row 8, we report the rearrest and reconviction numbers for new violent crimes alone (as we did in Table 4.A, Row 2). This comparison addresses the specific fear that employers, landlords, and policymakers might have about people with a past violent offense: that they will commit another violent crime. ${ }^{232}$ Although the rates of violent reoffense that we calculate are very slightly higher in the subsample with violent crime convictions, they are still extremely low in absolute terms. ${ }^{233}$ Only $0.3 \%$ of those who have had a violent offense expunged are reconvicted of another violent offense within two years, and only $0.8 \%$ within five years.

virtually any period of incarceration, no matter how brief, has consequences that negatively affect prisoners' lives in ways that resist adaptation, even after they have been released. Prisoners are often abandoned by their spouses and friends, face difficulty finding and keeping employment, and may suffer from incurable diseases contracted during their incarceration."); see also Manudeep Bhuller et al., Incarceration, Recidivism, and Employment, I28 J. POL. ECON. I269, I3I3 (2020) (noting that incarceration cripples a previously employed person's post-release employment prospects); Flake, supra note 86, at 55-62; David J. Harding et al., Imprisonment and Labor Market Outcomes: Evidence from a Natural Experiment, I24 AM. J. Soc. 49, 75-76 \& tbl.2 (2018); Steven Raphael, The Effects of Conviction and Incarceration on Future Employment Outcomes, in LABEling TheORY: EMPIRICAL TESTS 237, 259 (David P. Farrington \& Joseph Murray eds., 20I4); supra section I.A., pp. 2468-7 I.

231 Cf. J.J. Prescott et al., Understanding Violent-Crime Recidivism, 95 NOTRE DAME L. ReV. I643, I688-97 (2020) (finding that age is negatively related to recidivism risk among prison releasees).

232 See, e.g., id. at I643-45; Megan Denver, Justin T. Pickett \& Shawn D. Bushway, The Language of Stigmatization and the Mark of Violence: Experimental Evidence on the Social Construction and Use of Criminal Record Stigma, 55 CRIMINOLOGY 664, 675-76 (20I 7 ) (reporting a "substantial" increase in the perceived risk of recidivism for those convicted of violent crimes as compared to those convicted of nonviolent crimes, id. at 676); see also supra p. 25 I3. But see Michael M. O'Hear \& Darren Wheelock, Violent Crime and Punitiveness: An Empirical Study of Public Opinion, I03 MARQ. L. REV. (forthcoming 2020) (manuscript at 47-49) (on file with Marquette University Law School) (finding no evidence that public support for the punitive sentencing of individuals who commit violent crimes results from fear of violent-crime recidivism).

233 According to a national study of recidivism, i I\% of prisoners released for a violent offense are arrested during their first year following release for having committed a new violent offense, compared to $9 \%$ of those released for a property offense and $7 \%$ of prisoners released for a drug offense. ALPER ET AL., supra note 2 I4, at I I. 


\section{B. Interpretation and Implications}

Our recidivism analysis should, at the very least, dispel any notion that individuals who receive expungements under Michigan's law pose any particular risk of reoffending. And the same is likely to be true in other states considering similar record-clearing laws. Employers and landlords should rest assured that petition-based expungement laws with comparable requirements and waiting periods are unlikely to deny them access to information that they need to protect themselves or their employees, customers, or tenants.

But what are the broader implications of this analysis for expungement policy, both in Michigan and beyond? In particular, do the data allow us to say anything about the effects of broadening the availability of expungement - either procedurally (for example, by rendering it automatic) or substantively (by loosening eligibility requirements)? Expungement recipients are, again, an unrepresentative sample of individuals with criminal records. Primarily, they are self-selected - they had the motivation to apply for expungement, the belief that their case could be convincing to a judge, and the energy, money, and organizational skills to complete the application process. ${ }^{234}$ They are also filtered by judges' discretion, and judges presumably look for candidates who seem to be at low risk of committing future crime. So we cannot assume that subsequent crime rates for people who are not selected in the same way would be as low. And if they were not as low, would the public-safety objection then become legitimate?

To address these questions, we must consider two separate influences on post-expungement recidivism rates. The first is baseline risk: the risk of recidivism, absent expungement, of those same individuals. ${ }^{235}$ The second is the causal effect of expungement on these individuals' subsequent criminal behavior. ${ }^{236}$ Either or both could contribute to the low recidivism rates that we see in our expungement sample - that is, recipients could have been low risk regardless and/or the expungement of their record could have lowered their risk. Unfortunately, we do not have a good empirical technique for using our data to disentangle these two theories. This is mainly because of the key legal requirement for

\footnotetext{
234 See supra p. 2490 \& tbl.I; section II.C, pp. 250 I-Io (showing that the vast majority of individuals who are legally eligible for an expungement do not succeed in obtaining one and arguing that many potential recipients do not apply for record-clearing relief because of various institutional, psychological, and practical barriers).

235 See, e.g., Christopher Clapham \& James Nicholson, The Concise Oxford DiCTIONARY OF MATHEMATICS 39 (5th ed. 20I4) (defining baseline risk); $c f$. Natalie J. Jones et al., Predicting Criminal Recidivism in Adult Male Offenders: Researcher Versus Parole Officer Assessment of Dynamic Risk, 37 CRIM. JUST. \& BEHAV. 860, 86 I (2010) (distinguishing baseline or counterfactual risk from dynamic risk that incorporates changes in an individual's situation over time and is more tightly related to recidivism).

236 See, e.g., Adams et al., supra note 95, at 45 (arguing that expungement itself may cause a reduction in recidivism); Selbin et al., supra note 43 , at 57 (same).
} 
expungement: nonrecidivism. Recidivism rates are by definition zero before people become eligible for expungement and before they receive one, which means that a study with a "pre-post" design cannot meaningfully evaluate expungement's effects on recidivism.

Accordingly, to inform a discussion of what seems most likely to explain the low post-expungement recidivism risk we estimate, we turn for guidance to the criminological literature more broadly. Scholarship in this area provides strong support for both explanations for our empirical results. Expungement recipients probably have low baseline recidivism risk at the time they receive an expungement, and the receipt of an expungement probably lowers this risk further.

As to baseline risk, first, a key finding of the relevant research is that most people who commit crimes do not continue to do so forever. Within the large criminological literature on recidivism and patterns of desistance from crime, a small but important subset of work focuses on the extent to which older criminal records remain usefully predictive of future offending. ${ }^{237}$ In particular, it asks: When people have remained crime-free for a given period of time, at what point do they become no riskier, or at least not notably riskier, than the general population or people without criminal records? Alfred Blumstein and Kiminori Nakamura have labeled this concept "redemption" - suggesting that the passage of some number of recidivism-free years should be understood to "redeem" the individual in the eyes of society. ${ }^{238}$ Estimated times to redemption appear to vary across samples, crime types, age cohorts, and methods, but they are usually in the range of four to ten years, at least when juxtaposing individuals with records to the same age cohort within the general population. ${ }^{239}$

237 See, e.g., Alfred Blumstein \& Kiminori Nakamura, Extension of Current Estimates of Redemption Times: Robustness Testing, Out-of-State ARrests, AND RACIAL DIFFERENCES I-3 (20I2), https://www.ncjrs.gov/pdffilesi/nij/grants/2 40Ioo.pdf [https://perma.cc/BD4R-4GMV]; Alfred Blumstein \& Kiminori Nakamura, Redemption in the Presence of Widespread Criminal Background Checks, 47 CRIMINOLOGY 327, 33I-39 (2009); Shawn D. Bushway et al., The Predictive Value of Criminal Background Checks: Do Age and Criminal History Affect Time to Redemption?, 49 CRIMINOLOGY 27, 28-30 (20II); Megan C. Kurlychek et al., Enduring Risk? Old Criminal Records and Predictions of Future Criminal Involvement, 53 CRIME \& DELINQ. 64, 7 I-78 (2007); Megan C. Kurlychek et al., Scarlet Letters and Recidivism: Does an Old Criminal Record Predict Future Offending?, 5 CRIMINOLOGY \& PUB. POL'Y 483, 492-98 (2006).

238 See BlumSTEIN \& NAKAMURA, supra note 237, at 8. This religiously derived language has potential connotations (for example, the idea that those with records are "fallen") that are probably not intended by any of the scholars using it and that we do not endorse; still, we use the term here in deference to the leading work on desistance from crime.

239 See generally Blumstein \& Nakamura, supra note 237. If instead the contrast is drawn with only people who have no prior criminal record (instead of the general population, which includes people with records), then redemption studies tend to find that the recidivism risk of people with records never converges completely to the risk levels posed by individuals without records, see id. 
One could easily interpret the low recidivism rates we find in section III.A - and the favorable comparisons to general-population arrest rates - as indications of redemption. Expungement recipients have all gone at least five years without a subsequent conviction before receiving their expungement; the median period between conviction and expungement is nearly ten years. ${ }^{240}$ Moreover, by definition, expungement recipients in our data were all individuals without any prior record when they were convicted of their expunged offense - and recidivism studies consistently find that the length of one's existing criminal record is a strong predictor of subsequent recidivism. ${ }^{241}$ And, as we note above, the group that receives expungements is self-selected and selected by judges. Taken together, then, there are many reasons to believe expungement recipients may be at a low baseline risk for recidivism.

It is, however, also quite likely that receiving an expungement reduces a recipient's recidivism risk below their previous baseline. This possibility is supported by criminological research on the factors predicting recidivism. ${ }^{242}$ Recidivism-related benefits of expungements are likely to be mediated primarily by their effects on employment and wage levels - which we assess below in Part IV. Unemployment is a moderately strong predictor of recidivism. ${ }^{243}$ Likewise, higher weekly wages significantly reduce recidivism risk. ${ }^{244}$ A study of women with records indicates that "poverty status increases the odds of rearrest by a factor of 4.6 " and is a better predictor of rearrest than a recidivism-risk index

at 340-44; however, the difference eventually comes sufficiently close to zero that a reasonable observer would conclude that the old record provides no useful or actionable information, see id. at 343 fig. 4 .

240 See supra tbl.2.

241 See, e.g., U.S. Sentencing Comm'n, Measuring Recidivism: The Criminal History COMPUTATION OF THE FEDERAL SENTENCING GUIDELINES Io (2004).

242 Indeed, although direct empirical evidence has long been lacking, this argument has often been part of the policy case made for expungement laws. See, e.g., STANDARDS FOR CRIMINAL JUSTICE ch. I9, introductory cmt., at I3, § I9-2.5, cmt., at 33 (AM. BAR ASS'N 3d ed. 2004); Deborah N. Archer \& Kele S. Williams, Making America "The Land of Second Chances": Restoring Socioeconomic Rights for Ex-offenders, 30 N.Y.U. REV. L. \& Soc. CHANGE 527, 527-30 (2006); Andrew von Hirsch \& Martin Wasik, Civil Disqualifications Attending Conviction: A Suggested Conceptual Framework, 56 CAMBRIDGe L.J. 599, 605 (I997); Jeremy Travis et al., Prisoner Reentry: Issues for Practice and Policy, CRIM. JUST., Spring 2002, at I 2, I 7-I 8 .

243 See, e.g., Chi. Mayoral Policy Caucus, Rebuilding Lives. Restoring Hope. Strengthening Communities. I5 (2006); PAUl Gendreau et Al., CtR. FOR CRIMINAL Justice Studies, Case Needs Review: Employment Domain 5-7, i 2 (2000), https://www.csc-scc.gc.ca/research/o92/r9o_e.pdf [https://perma.cc/P89C-L8UM]; JOAN PETERsilia, When PRISONERS COME HOME 40-4I (2003); TrAVIS ET AL., supra note 3I, at 3I-33; Nicholas Freudenberg et al., Coming Home from Jail: The Social and Health Consequences of Community Reentry for Women, Male Adolescents, and Their Families and Communities, 95 AM. J. Pub. Health i 725, I 729 (2005).

244 Samuel L. Myers, Jr., Estimating the Economic Model of Crime: Employment Versus Punishment Effects, 98 Q.J. ECON. I57, I63 (1983). 
commonly used in corrections. ${ }^{245}$ Homeless individuals with criminal records are especially likely to recidivate, ${ }^{246}$ while people who receive educational programming while incarcerated are less likely to recidivate upon release. ${ }^{247}$ To the extent that criminal records limit access to quality housing, student loans, satisfying employment, and decent wages, expungement should reduce recidivism by mitigating each of these socioeconomic contributors to criminal behavior.

Another possibility is that expungement reduces recidivism by alleviating the social exclusion that is often associated with criminal records. People with records face significant social stigma, ${ }^{248}$ which is exacerbated by employers' growing reliance on increasingly available online criminal records databases. ${ }^{249}$ Sociologists and criminologists have long argued that social stigma and exclusion can contribute to criminal recidivism..$^{250}$ Although little empirical support has been found for the strongest claims of i 970 -era labeling theorists (for example, that labeling individuals renders criminal justice interventions actually counterproductive on net), ${ }^{251}$ stigma and exclusion may still be an important part of the dynamic underlying recidivism. ${ }^{252}$

All in all, it is highly plausible that expunging criminal records could benefit public safety, given what we know from a large body of research about recidivism patterns generally. In contrast, no similarly plausible empirical support exists for the opposite claim, one that lies behind resistance to expungement laws: that sealing records increases recidivism

245 Kristy Holtfreter et al., Poverty, State Capital, and Recidivism Among Women Offenders, 3 CRIMINOLOGY \& PUB. POL'Y i 85, I98 (2004).

246 See Stephen Metraux \& Dennis P. Culhane, Homeless Shelter Use and Reincarceration Following Prison Release, 3 CRIMINOLOGY \& PUB. POL'Y I39, I 5 I-53 (2004).

247 See Stephen J. Steurer \& Linda G. Smith, Corr. Educ. Ass'N, Education ReduCES CRIME: Three-STATE ReCidivisM STUdY 20-2 I (2003), https://files.eric.ed.gov/ fulltext/ED478452.pdf [https://perma.cc/DA 7 J-KHDF]; John Nuttall et al., The Effect of Earning a GED on Recidivism Rates, 54 J. CORRECTIONAL EDUC. 90, 92-94 (2003); Kristen M. Zgoba et al., The Influence of GED Obtainment on Inmate Release Outcome, 35 CRIM. JUST. \& BEHAV. 375, 376-77 (2008).

248 See Marc A. Franklin \& Diane Johnsen, Expunging Criminal Records: Concealment and Dishonesty in an Open Society, 9 HOFSTRA L. REV. 733, 736-37 (I98I).

249 See Nat'l Freedom of Info. Coal., Portal to Compliance: A Qualitative Analysis of Online Public Record Request Services in Major U.S. Cities 2-3 (20I9), https://www.nfoic.org/sites/default/files/pages/20I9-og/NFOIC\%20Portal\%20to\%20Compliance. pdf [https://perma.cc/PN 2 G-WC4 4 G]; Kurlychek et al., Enduring Risk? Old Criminal Records and Predictions of Future Criminal Involvement, supra note 237, at 65, 68.

250 See, e.g., William D. Payne, Negative Labels: Passageways and Prisons, I9 CRIME \& DELINQ. 33, 33-34 (I 973); Charles R. Tittle, Deterrents or Labeling?, 53 Soc. ForCES 399, 399-400 (I 975 ) (surveying the existing literature at the time on labeling "deviance" and whether labeling results in recidivism or deterrence).

251 See Tittle, supra note 250, at 402-04 (refuting the labeling argument).

252 See David R. Karp, The New Debate About Shame in Criminal Justice: An Interactionist Account, 2 I JUST. SYS. J. 30I, 305-07 (2000). 
risk. To our knowledge, those raising this objection have never presented evidence supporting it, and its rationale is not obvious.

The intuition seems to be that those who know an individual's criminal background can take steps to protect themselves - for example, by choosing not to hire the person. And as the empirical evidence we discuss in section I.A indicates, many U.S. employers do exactly that. But while such a step might be in an individual employer's or landlord's self-interest, it is hard to see how it would be in society's interest overall, given that lack of employment, unstable housing, and social stigma are all risk factors for recidivism. Even if a person with a record is at an elevated risk of committing crime, the employer who declines to hire that person simply shifts risks to others, or even amplifies those risks. ${ }^{253}$ No empirical research shows that the collective effect of decisions not to hire or rent to people with records makes society safer. Notably, the purported public-safety case against expungement follows the same logic as the purported public-safety case in favor of sex offender registries with public notification requirements - yet empirical research has shown that these laws may actually increase recidivism. ${ }^{254}$

With that in mind, let's return to the question we raise at the beginning of this section. Suppose that a state were considering making expungement more broadly available to those with records: making it automatic for some subset of individuals with records, shortening the waiting period, or loosening eligibility requirements. If these new classes of recipients have a higher baseline risk of recidivism than current recipients do, their post-expungement recidivism rates will also probably be higher - maybe substantially so.

But from a policy perspective, this possibility is a red herring. The higher recidivism risk would not be caused by the expungements or by the law change that allowed them; it is simply a baseline risk, which would exist with or without expungements. A higher recidivism rate is not relevant to the cost-benefit analysis unless it is an effect of the law change or the resulting expungements. But there is no credible evidence

253 There is at least one plausible counterargument. There may be situations in which someone with a history that includes a particular crime applies for a position that would put them in an especially favorable position to recommit the same or a similar offense. Further, that criminal opportunity would not be available at another location or with another employer. Many employers and landlords might prefer to use a public criminal record to reduce the likelihood that this person reoffends in that place or in that situation. However, while theoretically possible, situations of this sort in which crime is not simply displaced seem likely to be very few, and, more importantly, the negative effect that employment and housing difficulties can have on general recidivism factors is likely to overshadow any benefit. Cf. J.J. Prescott, Portmanteau Ascendant: Post-release Regulations and Sex Offender Recidivism, 48 CONN. L. REV. I035, I040, I057 (2016) (identifying this dynamic in the context of sex offender post-release regulations).

254 J.J. Prescott \& Jonah E. Rockoff, Do Sex Offender Registration and Notification Laws Affect Criminal Behavior?, 54 J.L. \& ECON. I6I, I8I (20II). 
to support the idea that risk might grow because of the greater availability of expungement relief. Meanwhile, existing research provides firm grounds to believe that, if anything, recidivism would fall. Put another way, if expungement reduces recidivism, then granting it to a pool of new recipients with higher underlying recidivism risk simply offers a greater potential public-safety upside.

\section{EMPLOYMENT OUTCOMES}

Although record clearing can simultaneously address a range of collateral consequences of criminal convictions, probably the most important motivation for most expungement applicants ${ }^{255}$ — and the most important policy rationale for expungement laws - is to improve access to employment. As we discuss in Part I, well-developed theoretical accounts convincingly explain why criminal record expungement should have positive employment consequences for recipients, but the empirical evidence on the question remains extremely limited.256 This is a huge problem as advocates and policymakers negotiate the future of expungement policies. In this Part, we hope to at least begin to resolve it. Section IV.A presents estimates and figures comparing pre- and postexpungement wage and employment trajectories for our large sample of recipients; these show large gains in both employment rates and wages following an individual's receipt of an expungement. Section IV.B addresses the question whether these gains can be interpreted as causal

\footnotetext{
255 A sample of individuals who received record-clearing relief in California "expressed frustration with their inability to gain employment [with their criminal record], noting that the limited jobs open to them predominantly involved poor working conditions and low pay .... They genuinely hoped record clearance would increase their employment potential and facilitate their successful reintegration into society." Adams et al., supra note 95, at 30. In another survey of people seeking expungement of criminal records in Chicago, participants reported suffering ongoing stigma from their record: "Even participants with extensive histories who had remained 'clean' for lengthy periods reported criminal record related stigma and material hardship." Ispa-Landa \& Loeffler, supra note 32, at 398. For example, "a 44-year-old man who had I 2 arrests on his rap sheet [and] had been convicted of drug possession and unlawful use of a weapon i 9 years earlier" said that "he could easily find several references who would vouch for his work ethic and skills, but even these personal testimonies did not compensate for his criminal record." Id.

256 See Megan Denver et al., A New Look at the Employment and Recidivism Relationship Through the Lens of a Criminal Background Check, 55 CRIMINOLOGY I 74, I76-77 (2017); see also $i d$. at I96; Pager, supra note 30, at 939-44; supra section I.C, pp. 2476-80. A handful of studies have been conducted at the county level and have concluded that expungement leads to positive employment outcomes overall. See Adams et al., supra note 95, at 45-47; Selbin et al., supra note 43, at 57-58; see also Meyli Chapin et AL., A Cost-Benefit ANAlysis OF CRiminal RECORD EXPUNGEMENT IN SANTA ClARA COUNTY 4 (20I4), https://publicpolicy. stanford.edu/publications/cost-benefit-analysis-criminal-record-expungement-santa-clara-county [https://perma.cc/M2 GZ-E5 ${ }_{5}$ CB]; Clean Slate Program, OfFice of The Pub. Def., City \& CTY. OF S.F., 2007-2008 Evaluation Findings 6 (2009), http://sfpublicdefender.org/wpcontent/uploads/sites/2/2009/o5/clean-slate-evaluation-final-report.pdf [https://perma.cc/J6V2-9XWF].
} 
effects of receiving an expungement, offering additional results to help us come to grips with this important question of interpretation.

\section{A. Employment and Wage Trajectories for Expungement Recipients}

The outcome data we use in this work are quarterly Unemployment Insurance Agency (UIA) wage data collected for expungement recipients. The data run from the third quarter of 1997 through the second quarter of 2013. The sample inclusion criteria we use to conduct our analysis are as follows: (I) The individual received an expungement on a known date between January I998 and May 20 I I. $^{257}$ (2) The individual did not possess a non-Michigan driver's license identified in our criminal history data. (3) The individual matched to the UIA data in at least one quarter during the period from I997 to 20I3. ${ }^{258}$ And (4) The individual is of working age (eighteen to sixty-four) for the entire time over which we observe their wages for a particular regression.

We examine both employment status and wages as outcomes. We structure our dataset for the research in this Part as a panel - that is, we follow the same individuals before and after they receive their expungement, and each observation is a person-quarter. ${ }^{259}$ For each analysis, we use a balanced panel, meaning that for every individual in our analysis (regardless of the date of receipt), we include the same number of quarters before and after the expungement. ${ }^{260}$ Essentially, we use each individual as their own control; we compare an individual's postexpungement employment-related trajectories with that same individual's pre-expungement trajectories.

In Table 5, we report estimated average changes in employment trends before and after an individual receives an expungement. The different columns of Table 5 present these estimated changes in trends

\footnotetext{
257 Within each column in Table 5, the sample is further constrained to ensure that outcome data exist for all person-quarters in the analysis. For example, if we have only five quarters of preexpungement data for particular individuals, we include them in the sample for Column 2, which considers two quarters of data before and after expungement, but we exclude them from the sample for Column 3, which includes eight quarters of data on either side of the expungement.

258 For those individuals who do match, we interpret an absence of reported wage data for a particular quarter as implying the individual has no employment in that quarter. By contrast, we take the total absence of someone from the wage data to imply a failure in the matching process (for example, a missing or incorrect Social Security number, or a non-Michigan resident).

259 For a brief summary of the advantages of using panel data, see CHENG HSIAO, ANALYsis OF PANEL DATA I-8 (2d ed. 2003).

260 See CHRistopher F. BAUM, AN INTRODUCTION TO MODERN ECONOMETRICS USING Stata 46-47 (2006); JefFrey A. EdWARdS, Building BetTer Econometric Models Using Cross Section and PANel Data 23 (20I4); MARkus MAYER, Unbalanced PANEL DATA MODELS (20I0), https://homepage.univie.ac.at/robert.kunst/pan20Io_pres_mayer.pdf [https://perma.cc/K92A-FSXJ].
} 
over different time windows of various widths; we place the expungement at the center of each window. We estimate the following equation using ordinary least squares:

$$
\begin{aligned}
& \text { Employed }_{i t}=\alpha+\gamma \text { Elapsed }_{i t}+\delta \text { Elapsed }_{i t} \times \text { Post }_{i t} \\
& +\theta \text { TotalEmployment }_{t}+\vartheta \text { URate }_{t}+\epsilon_{i t} .
\end{aligned}
$$

Our main outcome of interest, Employed, is an indicator for whether an individual has any positive wages reported to UIA by any employer in the quarter. ${ }^{261}$ Elapsed is a linear measure of time, increasing by one for each quarter; it is set to zero in the quarter before the individual receives their expungement. ${ }^{262}$ The coefficient we estimate on Elapsed represents the underlying linear trend in employment in the quarters prior to the expungement - that is, it is the average change per quarter in the employment rate for the sample. A negative coefficient on Elapsed would indicate that the group's average employment rate was declining prior to expungement receipt, and a positive coefficient would indicate that it was increasing.

Our primary variable of interest, Elapsed $\times$ Post, captures the change in the linear employment-rate trend after expungement receipt. A positive coefficient on Elapsed $\times$ Post implies that the employmentrate trend improves post-expungement, and a negative coefficient conversely means it gets worse. ${ }^{263}$ We estimate changes in the employment

261 "Any positive wages" is a very minimal threshold for deeming an individual "employed," as there is no minimum number of hours or total compensation requirement. Furthermore, the wages could come only from one part of the quarter; the wage data are not further broken down temporally. On the other hand, absence of employment/wages as measured in these data does not necessarily mean that the individual is truly "unemployed" in the sense that economists use the term that is, actively looking for a job, but so far unsuccessful. Being unemployed in our data simply means that the individual does not have a wage- or salary-paying job. Virtually all employers in Michigan are required to report wages, but the data do not include people who are self-employed, nor do they differentiate between unemployed people who are looking for work and people who are out of the workforce. See MICH. CoMp. LAWS ANN. \$ 42 I.I3(2) (West 2020). If our real outcome of interest is total lawful employment (including self-employment) among the working-age population, then presence in the UIA data is a rough proxy for it. UIA-reported wages may also understate total earnings. That said, these issues affect the data throughout the study period, and we do not think they should substantially affect our estimation of trend changes from before an expungement to after its receipt. If anything, classical measurement error like this tends generally to bias regression estimates toward zero - specifically, it may cause us to understate the true effect size of expungement. See JefFrey M. Wooldridge, ECONOMEtric AnAlysis of Cross SECTION AND PANEL DATA 73-75 (Ist ed. 2002); Andrew B. Abel, Classical Measurement Error with Several Regressors I6-I7 (May 9, 20I7) (unpublished manuscript), http://finance.wharton. upenn.edu/ abel/pdf_files_papers/attenuation\%2 obias\%20 I6.pdf [https://perma.cc/VL72-2LG8].

262 Positive values of Elapsed represent the number of quarters since the individual received their expungement. We count the quarters prior to the expungement, running from negative values up through quarter zero, which is the last quarter unaffected by the expungement.

263 The sum of the estimated coefficients of Elapsed and Elapsed $\times$ Post represent the postexpungement trend in the employment rate for this group; a positive sum means employment levels are increasing, and a negative sum means they are declining. 
trend, rather than a simple one-time change in the employment level, on the assumption that the effects of an expungement may accumulate over time rather than being instantaneous. ${ }^{264}$ We estimate linear trends (as opposed to more complicated curves) for simplicity of interpretation. But estimating these trends over a variety of time windows can help us to detect nonlinear patterns in the actual trajectory. ${ }^{265}$

The remaining variables in our estimating equation are measures for economic conditions during the calendar quarter of each observation. The time period of the analysis (I997-2013) includes considerable economic fluctuations, most importantly the 2008 financial crisis and subsequent deep recession; overall it was a period of economic decline and rising unemployment in Michigan. ${ }^{266}$ To account for these changes in the labor market, we include Michigan's quarterly unemployment rate and the total number of people employed in the state as reported by the Bureau of Labor Statistics. ${ }^{267}$ We control for these changing economic conditions because they could potentially affect the pre- and post-expungement periods differently. In contrast, because of the balanced-panel structure, fixed attributes of given individuals or

\footnotetext{
264 In addition, especially if there is an underlying trend over time before the expungement, estimating changes in levels alone can be misleading. For example, if there is a continuous upward trend throughout the sample period, the average level would be higher in the post-expungement period even if the growth has nothing to do with expungement receipt; at the same time, if there is a downward trend before the expungement that reverses after expungement receipt, the average employment levels might look the same before and after, even though there may have been a dramatic change in trajectory.

265 The results are substantively similar if we use logistic regression for the binary outcome variables, as we did in the Table 3 uptake analysis. Here, we prefer the linear probability model because our key variable of interest is an interaction term, and interactions are notoriously difficult to interpret in logistic regression. See Edward C. Norton et al., Computing Interaction Effects and Standard Errors in Logit and Probit Models, 4 STATA J. I54, I54-56 (2004). Linear probability models also tend to perform well in the middle of the probability distribution, a condition that is satisfied here (but not in the Table 3 analysis). See Paul von Hippel, Linear vs. Logistic Probability Models: Which Is Better, and When?, STATISTICAL HORIZONS (July 5, 20I5), https:// statisticalhorizons.com/linear-vs-logistic [https://perma.cc/7XZB-EAA3].

266 See Erin Duffin, Unemployment Rate in Michigan from Ig9z to 20Ig, StATisTa (Mar. 5, 2020), https://www.statista.com/statistics/I89438/unemployment-rate-in-michigan-since-I992 [https:// perma.cc/YA9U-4LWY]; Dustin Walsh, A Decade After Financial Crisis, Michigan Still Recovering, CRAIN'S DETROIT BUS. (Sept. I6, 20I8, I2:0I AM), https://www.crainsdetroit.com/economy/ decade-after-financial-crisis-michigan-still-recovering [https://perma.cc/7 RA7-UNSF]. We observe each individual in the sample only for much shorter - and differing - parts of this period, so fluctuations will affect each of them differently, which should reduce the aggregate effect of this variation, if any, on our estimates.

267 See generally Geographic Profile of Employment and Unemployment: Archive, U.S. BUREAU LAB. STAT., https://www.bls.gov/opub/geographic-profile/archive.htm [https://perma.cc/ZAS2$\mathrm{LE}_{52}$ ] (reporting, among other things, annual state averages for total employment and the unemployment rate among the civilian noninstitutional population).
} 
their prior criminal records can be safely ignored, since they are equally present before and after the receipt of the expungement. ${ }^{268}$

In each version of the regression results in Table $5,{ }^{269}$ we estimate a substantial and statistically significant $(p<0.00 \mathrm{I})$ upward turn in the employment-rate trajectory of expungement recipients after they receive their expungements. ${ }^{270}$ The coefficients, representing per-quarter gains, decline in magnitude as the window gets larger (although they remain significant), which intimates that the improvements are steepest in the first two quarters and slowly become more gradual; this can also be seen in the net gain and proportional net gain calculations we report in Table $5 .{ }^{271} \mathrm{By}$ the end of one year, after controlling for the pre-receipt trend and other potentially confounding labor-market variables, expungement recipients gain nearly eight percentage points in their employment rate; proportionally, they are I.I3 times as likely to be employed. The net gain following expungement is about the same in the two-year observation period and slightly lower in the three-year period, suggesting not only that the employment improvements following an expungement come relatively quickly, but also that they are largely sustained in the following years.

In Panel B of Table 5, we show the same type of analysis, but substitute a different, less minimalist definition of the employment outcome variable. Instead of requiring only that any wages have been earned at any time in the quarter, Employed now requires individuals to have earned an average of at least $\$$ I00 a week (\$I300 total for the quarter) before they count as employed. This is still a threshold that falls well

\footnotetext{
268 The standard errors that we estimate for these regressions are clustered at the person level; clustering in this way means that the reported precision of our estimates accounts for the fact that our quarterly observations for each person are not independent of one another.

269 The "window" range we indicate at the top of each column in Table 5 reflects the number of quarters before and after expungement receipt and thus the sample over which we estimate our regressions; for example, " $+/-4$ " means that we observe individuals for one year before (four quarters) and one year after the expungement.

270 The $p$-value represents the probability that a randomly drawn sample of the size used by the researcher would produce the observed coefficient (or a more extreme one) if the true coefficient of the relationship in the underlying population were zero. It is a way of expressing statistical imprecision due to sampling error. See B.S. EveritT \& A. Skrondal, The CAMbridge Dictionary OF STATISTICS 307 (4th ed. 20I0) (defining "null hypothesis"); Valen E. Johnson, Revised Standards for Statistical Evidence, I Iо PNAS г93 I3, I93І3 (2013). A p-value of .05 or less is generally considered statistically significant, though even lower is better. See Johnson, supra, at I9313, I9315.

271 Near the bottom of each Panel in Table 5, "net gain" and "proportional net gain" show the estimated percentage-point and proportional gains in employment experienced by the average expungement recipient by the window's end, relative to what would have occurred had they stayed on their pre-expungement trajectory. We calculate "net gain" by multiplying the estimated Elapsed $\times$ Post coefficient by the number of quarters observed in the post-expungement period in the column. We calculate "proportional net gain" by dividing the net gain by the average employment level in the quarter before expungement receipt (which is 61.7\%).
} 
short of representing full-time employment. ${ }^{272}$ Even so, by using this definition, we at least exclude truly trivial earnings that may be causing people who are for all practical purposes unemployed to be coded for our analysis as employed. And, importantly, it may allow us to pick up on some differences that the main Employed coding misses.

And indeed, the results in Panel B show substantially larger trend changes than we display in Panel A. The general pattern is the same steeper trend changes in the narrower windows - but the magnitudes are larger. By the end of one year, we now see a twelve-percentagepoint net gain in employment relative to the pre-expungement trajectory. This implies that expungement recipients are I.23 times as likely to be making at least $\$$ Ioo/week as they would have been $(53 \%$ are employed at baseline using this measure of employment). As before, the net gains are similar in the two-year window and slightly lower in the threeyear window, indicating that the employment gains largely endure but do not continue to increase after the first year.

In Panel $\mathrm{C}$ of Table 5 , we estimate changes in the average wage trajectory of individuals following expungement receipt. We find a similar pattern, with a steep gain in the first year followed by a subsequent plateau in gains. By the end of the first year, relative to the pre-receipt trend, recipients gain an average of \$III I in quarterly wages (that is, $\$ 4444$ per year), which is a $23 \%$ improvement over the pre-expungement average; the net gain increases to \$I234 in the two-year estimate, a $25 \%$ improvement. The proportional increase in wages is much larger than the increase in the employment rate in Panel A, but very close to the gain we calculate using the alternative employment measure in Panel B. This pattern implies that the increase in average wages may substantially be explained by unemployed people obtaining employment or by very minimally employed people securing more hours or higher-paying work following their expungement. In Figures $3 \mathrm{~A},{ }_{3} \mathrm{~B}$, and ${ }_{3} \mathrm{C}$, we demonstrate visually the employment and wage patterns that underlie these regression estimates. ${ }^{273}$ These graphs show only raw averages by quarter before and after expungement receipt; they are not regression-

\footnotetext{
272 The minimum wage in Michigan was in the vicinity of $\$ 7$ per hour throughout our sample period. See Changes in Basic Minimum Wages in Non-farm Employment Under State Law: Selected Years 1968 to 20I9, U.S. DEP'T LAB.: WAGE \& HOUR DIVISION (Jan. 2020), https://www.dol.gov/agencies/whd/state/minimum-wage/history [https://perma.cc/MVJ7-ZELL]. Therefore, this measure of employment represents about fourteen hours of work per week at minimum wage, or less at a higher wage; $\$$ Ioo/week is less than one-fifth of the median wage among persons with any wage in our sample.

273 In these figures, we do not model changes in employment outcomes as linear trends during the pre-expungement and post-expungement periods. We simply show the employment rate and average wage for each quarter beginning two years before and ending two years after the expungement (including quarter $\circ$, the quarter immediately preceding the expungement quarter, which is marked with a vertical dotted line), and then we connect the dots. The sample we use to create the graphs is the same that we use for Column 3 in Table 5, Panels A-C. The graphs all have similar patterns - a clear V-shape immediately surrounding the expungement.
} 
TABLE 5. CHANGES IN EMPLOYMENT AND WAGE TRENDS AFTER EXPUNGEMENT

(Full Employment-Outcomes Sample)

\begin{tabular}{|c|c|c|c|c|}
\hline & (1) & (2) & (3) & (4) \\
\hline Window (Quarters) & $+/-2$ & $+/-4$ & $+/-8$ & $+/-12$ \\
\hline \multicolumn{5}{|l|}{ A. Employment Rate } \\
\hline \multicolumn{5}{|l|}{ (= any wages $)$} \\
\hline Elapsed $\times$ Post & $\begin{array}{l}0.0260 * * * \\
(0.003)\end{array}$ & $\begin{array}{l}0.0198 * * * \\
(0.002)\end{array}$ & $\begin{array}{l}0.00945 * * * \\
(0.001)\end{array}$ & $\begin{array}{l}0.00521 * * * \\
(0.0006)\end{array}$ \\
\hline Elapsed & $\begin{array}{l}-0.00710 * * * \\
(0.002)\end{array}$ & $\begin{array}{l}-0.00649 * * * \\
(0.001)\end{array}$ & $\begin{array}{l}-0.00346 * * * \\
(0.0006)\end{array}$ & $\begin{array}{l}-0.00237 * * * \\
(0.0004)\end{array}$ \\
\hline Net Gain & 0.052 & 0.079 & 0.076 & 0.063 \\
\hline Proportional Net Gain & $8.4 \%$ & $12.8 \%$ & $12.3 \%$ & $10.2 \%$ \\
\hline Number of Observations & 71,899 & 125,451 & 226,525 & 301,089 \\
\hline \multicolumn{5}{|l|}{ B. Employment Rate } \\
\hline Elapsed $\times$ Post & $\begin{array}{l}0.0367 * * * \\
(0.003)\end{array}$ & $\begin{array}{l}0.0308 * * * \\
(0.002)\end{array}$ & $\begin{array}{l}0.0149 * * * \\
(0.001)\end{array}$ & $\begin{array}{l}0.00838 * * * \\
(0.001)\end{array}$ \\
\hline Elapsed & $\begin{array}{l}-0.0144 * * * \\
(0.002)\end{array}$ & $\begin{array}{l}-0.0124 * * * \\
(0.001)\end{array}$ & $\begin{array}{l}-0.00562 * * * \\
(0.0006)\end{array}$ & $\begin{array}{l}-0.00320 * * * \\
(0.0004)\end{array}$ \\
\hline Net Gain & 0.073 & 0.123 & 0.119 & 0.101 \\
\hline Proportional Net Gain & $13.8 \%$ & $23.2 \%$ & $22.4 \%$ & $18.9 \%$ \\
\hline Number of Observations & 71,899 & 125,451 & 226,525 & 301,089 \\
\hline \multicolumn{4}{|l|}{ C. Quarterly Wages } & (U.S. dollars) \\
\hline Elapsed $\times$ Post & $\begin{array}{l}314.5 * * * \\
(36.77)\end{array}$ & $\begin{array}{l}277.8 * * * \\
(18.12)\end{array}$ & $\begin{array}{l}154.2 * * * \\
(10.38)\end{array}$ & $\begin{array}{l}92.22 * * * \\
(7.80)\end{array}$ \\
\hline Elapsed & $\begin{array}{l}-160.5 * * * \\
(22.26)\end{array}$ & $\begin{array}{l}-113.5 * * * \\
(11.78)\end{array}$ & $\begin{array}{l}-43.57 * * * \\
(7.32)\end{array}$ & $\begin{array}{l}-14.95 * \\
(6.10)\end{array}$ \\
\hline Net Gain & $\$ 628.98$ & $\$ 1,111.35$ & $\$ 1,233.37$ & $\$ 1,106.69$ \\
\hline Proportional Net Gain & $12.8 \%$ & $22.6 \%$ & $25.1 \%$ & $22.5 \%$ \\
\hline Number of Observations & 71,899 & 125,451 & 226,525 & 301,089 \\
\hline \multicolumn{5}{|l|}{$\underline{\text { Controls }}$} \\
\hline BLS Total Employment & $\mathrm{X}$ & $\mathrm{X}$ & $\mathrm{X}$ & $\mathrm{X}$ \\
\hline BLS Unemployment Rate & $\mathrm{X}$ & $\mathrm{X}$ & $\mathrm{X}$ & $\mathrm{X}$ \\
\hline
\end{tabular}

Notes: Outcome data come from Michigan's Unemployment Insurance Agency (UIA). The "window" refers to the length of the evaluation period and indicates the number of quarters before and after the expungement for example, " $+/-2$ " means a four-quarter (one year) evaluation period, with two quarters before and two quarters after the expungement. The sample includes quarterly data from individuals who received a knowndate expungement between January 1998 and May 2011, did not have an out-of-state driver's license, matched to the UIA data in at least one quarter of the sample period, and were of working age (eighteen to sixty-four) for the entire observation period indicated in the column's window. Standard errors clustered on the person are reported in parentheses. ${ }^{+}, *, * *$, and $* * *$ represent significance at the $10 \%, 5 \%, 1 \%$, and $0.1 \%$ level, respectively. 
adjusted to control for economic trends in Michigan. And, notably, the downward overall pattern in each of the graphs reflects the declining state of Michigan's economy over the course of our study period. But what is important to understand for our purposes is not that underlying decline but the change in the direction of the graph in the period immediately after the expungement - the sudden, V-shaped upturn.

The results that we show here are robust; that is, similar patterns consistently continue to appear even if we vary the details of the regression specification or the sample definition. ${ }^{274}$ For example, there are certain additional economic control variables that could potentially improve our ability to account for the influence of economic fluctuations, but which we do not add to the main specification because we do not have the data for all years. These include the average quarterly earnings for Michigan from the Quarterly Workforce Indicators series (available from 200I) and average quarterly wages and employment rates for expungement nonrecipients in our own data (available from 2004). For the years that they are available, adding these variables into our analysis does not change the results. In addition, one might worry that, nonetheless,

\section{FigURE 3A. EMPlOYMENT RATE (ANy WAGES) BEFORE AND AFTER EXPUNGEMENT}

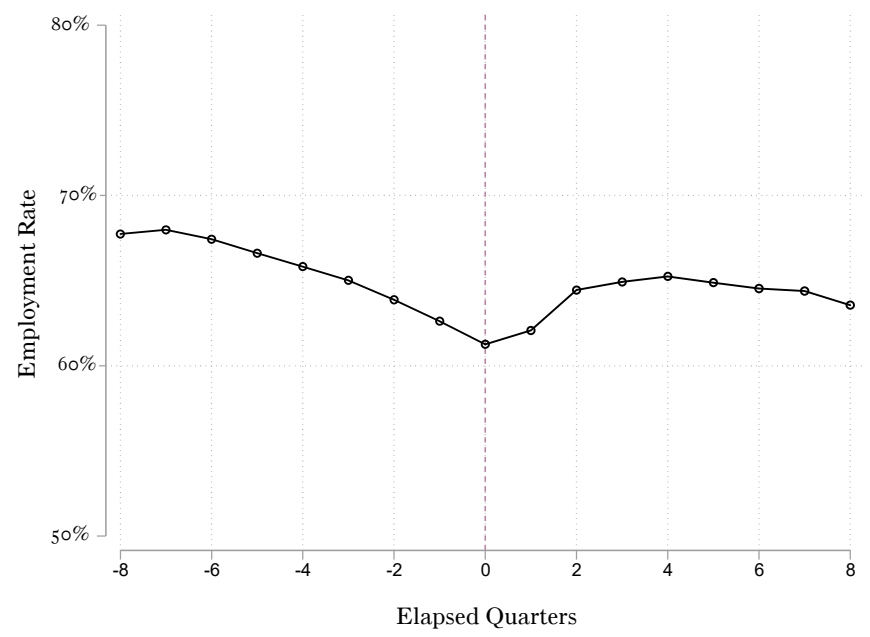

Notes: Quarter I (immediately after the dotted line) is the quarter of expungement receipt. The sample consists of individuals who received a known-date expungement between January I998 and May 20II, did not have an out-ofstate driver's license, matched to our UIA data in at least one quarter during the period from 1997 to 2013 , and were of working age (eighteen to sixty-four).

274 Cf. Ricardo A. Maronna et al., Robust Statistics: Theory and Methods (WITH R) I-2 (2d ed. 20I9) ("Classical statistical inference quantities . . . can be adversely influenced by the presence of even one outlier in the data. In contrast, appropriately constructed robust versions of those inference quantities are little influenced by outliers."). 
FigURE 3B. EMPLOYMENT RATE ( $>$ \$IOO/WEEK) BEFORE AND AFTER EXPUNGEMENT

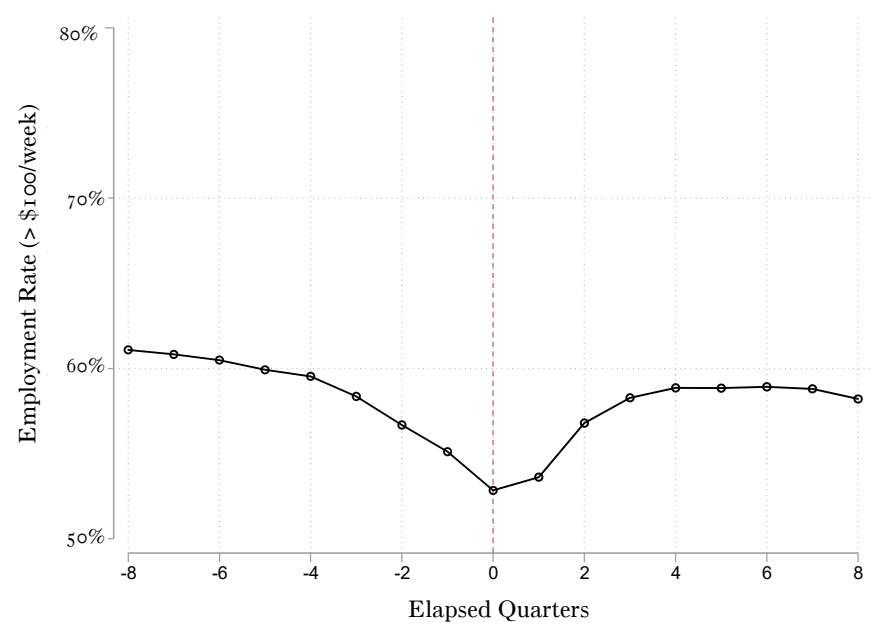

Figure 3C. Average Quarterly Wages BEFORE AND AFTER EXPUNGEMENT

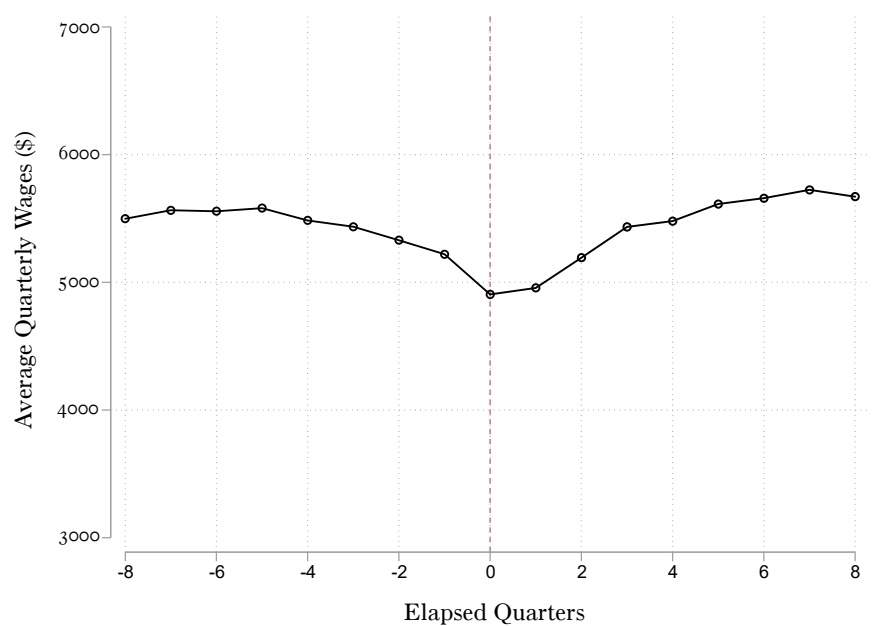

Notes: Quarter I (immediately after the dotted line) is the quarter of expungement receipt. The sample consists of individuals who received a known-date expungement between January I998 and May 20II, did not have an out-ofstate driver's license, matched to our UIA data in at least one quarter during the period from I997 to 20I3, and were of working age (eighteen to sixty-four) 
these controls might somehow not fully account for the major swings introduced by the financial crisis and recession. But the same patterns in our data persist if we simply drop that entire time period, such that the windows for each analysis end before 2008 begins. The same substantive story also surfaces if we leave in the sample all of the individuals who do not match to the wage data at all; for our main sample definition, we assume their absence was likely just a failure of the matching process, but they could also be people who were not working for the entire period. If we include them and count them as having zeroes for all of the outcome variables, the employment rate and average wages drop, and our point estimates decline proportionally, but the proportional net gain estimates remain the same.

We also conduct these analyses separately for different subpopulations to see whether expungement affects different groups of recipients differently. We find substantial, and largely similar, trend changes in every subgroup. The most conspicuous pattern we discover is that wage and employment gains are much larger for women, at least in proportional terms (women have lower baseline wages). For example, in the one year after expungement, we estimate that men's wages increase by I $7 \%$, while women's wages appear to increase by $30 \%$. We are unable to explain the difference, as there are many possible explanations; for example, perhaps women apply disproportionately to job types for which a criminal record is a particularly serious barrier. ${ }^{275}$ Studies of other kinds of job-access interventions, like job training, also generally find much larger effects for women, so the difference in our data may be a byproduct of a more general phenomenon. ${ }^{276}$ We also find larger effects for black expungement recipients than for white recipients, but this difference is not as large (one-year wage gains of $25 \%$ versus $18 \%$ ). Among both men and women, people who expunge a felony see only slightly larger gains than those who expunge a misdemeanor (one-year wage gains of $33 \%$ versus $29 \%$ among women, and $18 \%$ versus $16 \%$ for men). This difference seems surprisingly small, given that felonies carry more collateral consequences and presumably more labor-market stigma. ${ }^{277}$ However, relatively few misdemeanors are expunged in the first place, so they may represent a highly selected subset — for example,

\footnotetext{
275 A 2019 Bureau of Labor Statistics survey reports that women dominate fields like social work ( 8 I. $9 \%$ women), teaching young children ( $98.7 \%$ women), and home health care $(88.3 \%$ women) they are more likely to work with sensitive information and vulnerable populations. Labor Force Statistics from the Current Population Survey, U.S. Bureau LAB. STAT., https://www. bls.gov/cps/cpsaati I.htm [https://perma.cc/ENU - EML $_{5}$ (last updated Jan. 22, 2020). More employers in these fields probably conduct background checks — in fact, background checks are required by law for any childcare provider. Background Checks: What You Need to Know, CHILDCARE.GOV, https://www.childcare.gov/index.php/consumer-education/background-checkswhat-you-need-to-know [https://perma.cc/GZ59-BVNR].

276 See infra note 34I and accompanying text.

277 See Christopher Uggen et al., The Edge of Stigma: An Experimental Audit of the Effects of Low-Level Criminal Records on Employment, $5_{2}^{2}$ CRIMINOLOGY 627, 647 (20I4).
} 
perhaps the misdemeanors people choose to expunge tend to be particularly stigmatizing for them. In any case, the estimates for all crime categories and for all categories of individuals are large and significant.

\section{B. Interpretation: Expungement Effect, Motivation, or Mean Regression?}

Our analysis demonstrates that expungement is associated with large improvements in the employment rate and wages on average - and, in particular, a reversal of the pre-expungement downward trend that we observe for recipients as a group. Can we conclude from this evidence that expungements cause these improvements? The answer is not obvious. A causal interpretation of the trend-change estimates above depends on the assumption that, in the absence of these individuals receiving expungements, their collective pre-expungement employment and wage trajectories would have continued on the same path. But is that true? Absent expungement, is there some other force that might reverse the downward slide at about the same time as receipt and give rise to the same $\mathrm{V}$-shaped pattern we observe? The control variables in the regression already account for the role of changing labor-market trends, which would otherwise be one plausible explanation. But there is still the possibility of omitted variable bias - there could be something else going on that we cannot measure or observe that accounts for these patterns, other than the receipt of an expungement. ${ }^{278}$

The most likely candidate is motivation. As we detail in Part II, it takes a lot of effort, as well as a financial investment, to obtain an expungement. ${ }^{279}$ Moreover, most expungement recipients choose not to go through this effort as soon as they become eligible - three-quarters wait more than a year, and $44 \%$ wait more than five years. ${ }^{280}$ So, what motivates people who have waited several years to decide that now is the time to apply? From an inference perspective, it would be ideal if their decision were random, but it probably is not. For many, it may be that they are trying to get a job - perhaps because they have been laid off, or because they are seeking out better pay. ${ }^{281}$ This latter theory finds

278 Omitted variable bias (OVB) (or selection bias, in this case) is almost always a challenge in observational studies that seek to identify treatment effects. See Helene Starks et al., The Challenge of Selection Bias and Confounding in Palliative Care Research, I2 J. PAlliative MED. I8I, I8I (2009), https://www.ncbi.nlm.nih.gov/pmc/articles/PMC2982715/pdf/jpm.2009.9672.pdf [https:// perma.cc/YJH8-EKUZ]. However, in at least some employment-related contexts, OVB may not ultimately result in significant bias. See generally Marco Caliendo et al., Unobservable, but Unimportant? The Relevance of Usually Unobserved Variables for the Evaluation of Labor Market Policies, 46 LAB. ECON. I4 (20I7).

279 See supra section II.A, pp. 2488-93; supra section II.C, pp. 250 I-IO.

280 See supra fig. I and accompanying text.

$281 \mathrm{Cf}$. Adams et al., supra note 95, at 30 (noting that prior to record clearance, "[q]uintessential good jobs - those in specialized fields such as health care; jobs that provided good benefits such 
some support in our findings in Column 5 of Table 3: People are more likely to receive an expungement within a year of a job loss or substantial decline in wages. And a person who is motivated to improve their employment situation to the point that they are willing to go through the burdensome expungement process is probably taking other steps to better their prospects, too - like applying for jobs, obviously. So, if we see a turnaround in their employment trajectory just after the receipt of their expungement, could the change actually be due to these other steps, with the expungement merely incidental?

A related causal-inference concern is the possibility that our empirical findings are simply the product of statistical regression toward the mean. ${ }^{282}$ Consider a classic example often used to explain the concept: both very tall parents and very short parents tend, on average, to have children who are a little closer to the population's average height than they are. ${ }^{283}$ Although height is substantially hereditary, people do not turn out exactly like their parents; there is randomness involved in gene mixing and in the operation of other influences on height. Parents who are extremely tall or short are likely that way partly because of random noise, and their children are unlikely to get the same roll of the dice. ${ }^{284}$ Similar patterns are found in other real-world phenomena involving random fluctuations - extreme outcomes tend to be followed by less extreme ones ${ }^{285}$ for the straightforward reason that most outcomes are, by definition, not extreme. ${ }^{286}$

A similar phenomenon could explain some of our results. Suppose there is a certain amount of random variation in individual wages and employment status (or as good as random for our purposes - uncorrelated with the other variables of interest in our analysis). Suppose further that people tend to apply for expungement when they have recently

as health insurance, retirement plans, etc.; and jobs with the local, state, or federal government were particularly difficult to secure"); Ispa-Landa \& Loeffler, supra note 32, at 389 ("Historically, [criminal justice system (CJS)-marked individuals] could find employment in the manufacturing sector and other portions of the economy that had less direct contact with members of the general public. However, with deindustrialization, retail and other service sector jobs have largely replaced manufacturing jobs. These pay lower initial wages and offer fewer opportunities for wage progression. Furthermore, because retail and service sector jobs involve extensive contact with the public, employers may be especially reluctant to hire CJS-marked individuals." (citations omitted)).

282 For an explanation and examples of the statistical phenomenon, see generally Adrian G. Barnett et al., Regression to the Mean: What It Is and How to Deal with It, 34 INT'L J. EPIDEMIOLOGY 2 I 5 (2005).

283 Charlotte M. Wright \& Tim D. Cheetham, The Strengths and Limitations of Parental Heights as a Predictor of Attained Height, 8I ARCHIVEs Disease ChILdHOOD 257, 257 (I999) ("However, where parents were unusually tall or short, their children were relatively less tall or short, respectively ....")

284 See J. Martin Bland \& Douglas G. Altman, Statistics Notes: Regression Towards the Mean, 308 BRIT. MED. J. I499, I499 (I994) ("This is a statistical, not a genetic phenomenon.").

285 See Barnett et al., supra note 282 , at 217.

286 See John R. Nesselroade et al., Regression Toward the Mean and the Study of Change, 88 PSYCHOL. BULL. 622, 624-25 (I980). 
experienced an employment setback, so they are more likely to seek relief when they are on the downside of one of these random fluctuations. Then, even leaving to one side any broader job-search motivation that may be correlated with an individual interest in expungement, one might expect that downward trend to reverse itself at around the time an individual receives an expungement. Our analysis assumes that an existing downward trend in employment outcomes observed across a sample should be expected to continue without some clear reason for it to change - like receiving an expungement. Such an expectation is sensible when the underlying trend is driven by durable, real-world factors. But if the trend is not substantive but rather the product of random noise, then such an expectation can confound causal inference and lead one astray, especially when a trough in employment circumstances activates an understandable tendency among those eligible to apply for an expungement, inducing a spurious correlation.

Unfortunately, there is no entirely clean way to unravel these causal conundrums in our data. In truth, it is likely that all of these factors contribute to the large apparent employment effects we find - that is, expungements do bring about employment gains, but the gains caused by expungement receipt are not quite as large as those we estimate above. Indeed, the effects of motivation spillovers and record clearing might be expected to be mutually reinforcing: perhaps the motivation drives the job search, but the expungement makes the search more likely to be successful (and that prospect in turn may increase motivation), suggesting an even more reticulated causal story.

Fortunately, our data do provide a couple of reasons to believe that causal effects of expungements probably explain at least a large part of the trend changes we observe. The first reason concerns the exact timing of the upturn. The motivation and mean-regression theories both hinge on the idea that people apply for expungements at particular times: when they are motivated to seek work and/or when they have recently experienced the loss of a job or wages. But there is a significant period of time between application and receipt, and our analysis focuses on the date of receipt of the expungement. It takes at least a few months to receive an expungement, ${ }^{287}$ and this time lag implies that, in our quarterly wage data, any motivation or mean-regression effects should begin to be visible even two quarters before and definitely one quarter before

287 Lamentably, we do not know the date of the application for expungement in the great majority of observations in our data, and the time lag between application and receipt reportedly varies by a fair amount, depending on geography and so forth. But our conversations with expungement lawyers in Michigan and with representatives of the Michigan State Police suggest that it is very hard to complete the process in less than two months, and that (while some jurisdictions have recently achieved efficiency improvements) three to six months was a more common lag during the years covered by our study. See supra note r6 I and accompanying text. 
expungement receipt. We might expect to detect motivation effects even earlier because the impetus to seek a job might often be around for a while before any expungement application.

But what we see in the data does not seem to match this alternative story - or at least, it matches it at best only weakly. In Figures $3 \mathrm{~A},{ }_{3} \mathrm{~B}$, and ${ }_{3} \mathrm{C}$, the first quarter in which there is a change in trajectory - an upswing from the prior quarter - is quarter $\mathrm{I}$, the quarter in which the individual actually receives the expungement. ${ }^{288}$ In that quarter, we spot a very slight improvement from the previous quarter - which does represent a substantial change, stopping the previous downward trajectory - and a much steeper upward pivot between quarters I and 2 for the first employment curve (Figure $3 \mathrm{~A}$ ), and between quarters 2 and 3 for Figures ${ }_{3} \mathrm{~B}$ and ${ }_{3} \mathrm{C}$. This type of pattern is very much what we would expect to observe if expungement receipt (and not other factors correlated with an expungement application) drives the change in trajectory. ${ }^{289}$ If the shift in the trend were instead triggered by something happening a quarter or two earlier (e.g., the motivation accompanying the choice to apply for an expungement), we would likely see a similar pattern, only shifted a quarter or two to the left. But we see no trend change until quarter I in any of these graphs. ${ }^{290}$ It $i s$ possible that what occurs between quarter $\mathrm{O}$ and quarter I includes some component of the mean-reversion or motivation effect - we cannot rule this out. But the pattern is more consistent with changes being driven at least quite substantially by expungement receipt.

Second, we provide a further test of this causal theory in Table 6 by analyzing a specific subset of our sample: those who receive expungements within one year of becoming eligible to apply. As we explain above, we consider these cases (accounting for $25 \%$ of all expungements, and $19 \%$ of the wage-linked sample) to be primarily "pent-up demand" cases - people just waiting to become eligible. ${ }^{291}$ These individuals are obviously motivated to obtain an expungement, but there is no reason to believe that this motivation would have materialized just at the time of their application or, alternatively, as a consequence of some recent

\footnotetext{
288 See supra section IV.A, pp. 2524-33.

289 We only discern about half of the trend change in the partial post-expungement quarter (quarter I); the trend change appears in the figures in full bloom beginning only in the first quarters that fall fully in the post-expungement period.

290 Indeed, in the wage graph (Figure $3 \mathrm{C}$ ), the fall between quarters $-\mathrm{I}$ and $\circ$ is particularly steep.

291 See supra notes I60-I6I and accompanying text.
} 
TABLE 6. CHANGES IN EMPLOYMENT AND WAGE TRENDS AFTER EXPUNGEMENT

\begin{tabular}{|c|c|c|c|c|}
\hline Window (Quarters) & $\begin{array}{c}(1) \\
+/-2\end{array}$ & $\begin{array}{c}(2) \\
+/-4\end{array}$ & $\begin{array}{l}(3) \\
+/-8\end{array}$ & $\begin{array}{c}(4) \\
+/-12\end{array}$ \\
\hline \multicolumn{5}{|l|}{ A. Employment Rate } \\
\hline Elapsed $\times$ Post & $\begin{array}{l}0.0231 * * * \\
(0.007)\end{array}$ & $\begin{array}{l}0.0173 * * * \\
(0.004)\end{array}$ & $\begin{array}{l}0.00884 * * * \\
(0.002)\end{array}$ & $\begin{array}{l}0.00521 * * * \\
(0.0016)\end{array}$ \\
\hline Elapsed & $\begin{array}{l}-0.00151 \\
(0.004)\end{array}$ & $\begin{array}{l}-0.00529 * \\
(0.002)\end{array}$ & $\begin{array}{l}-0.00217+ \\
(0.0013)\end{array}$ & $\begin{array}{l}-0.00213 * \\
(0.0010)\end{array}$ \\
\hline Net Gain & 0.046 & 0.069 & 0.071 & 0.063 \\
\hline Proportional Net Gain & $7.6 \%$ & $11.4 \%$ & $11.6 \%$ & $10.3 \%$ \\
\hline Number of Observations & 13,386 & 23,184 & 42,075 & 55,293 \\
\hline \multicolumn{5}{|l|}{ B. Employment Rate } \\
\hline Elapsed $\times$ Post & $\begin{array}{l}0.0230 * * \\
(0.007)\end{array}$ & $\begin{array}{l}0.0215 * * * \\
(0.004)\end{array}$ & $\begin{array}{l}0.0125 * * * \\
(0.002)\end{array}$ & $\begin{array}{l}0.00742 * * * \\
(0.002)\end{array}$ \\
\hline Elapsed & $\begin{array}{l}-0.00364 \\
(0.004)\end{array}$ & $\begin{array}{l}-0.00605 * * \\
(0.002)\end{array}$ & $\begin{array}{l}-0.00217 \\
(0.0013)\end{array}$ & $\begin{array}{l}-0.00132 \\
(0.0011)\end{array}$ \\
\hline Net Gain & 0.046 & 0.086 & 0.100 & 0.089 \\
\hline Proportional Net Gain & $8.8 \%$ & $16.5 \%$ & $19.2 \%$ & $17.1 \%$ \\
\hline Number of Observations & 13,386 & 23,184 & 42,075 & 55,293 \\
\hline \multicolumn{5}{|l|}{ C. Quarterly Wages } \\
\hline Elapsed $\times$ Post & $\begin{array}{l}227.8 * * \\
(70.00)\end{array}$ & $\begin{array}{l}211.1 * * * \\
(39.96)\end{array}$ & $\begin{array}{l}128.6 * * * \\
(23.11)\end{array}$ & $\begin{array}{l}59.70 * * * \\
(17.24)\end{array}$ \\
\hline Elapsed & $\begin{array}{l}-17.76 \\
(41.44)\end{array}$ & $\begin{array}{l}-25.56 \\
(24.46)\end{array}$ & $\begin{array}{l}9.292 \\
(15.95)\end{array}$ & $\begin{array}{l}31.45 * \\
(13.08)\end{array}$ \\
\hline Net Gain & $\$ 455.68$ & $\$ 844.25$ & $\$ 1,028.88$ & $\$ 716.45$ \\
\hline Proportional Net Gain & $10.6 \%$ & $19.6 \%$ & $23.9 \%$ & $16.6 \%$ \\
\hline Number of Observations & 13,386 & 23,184 & 42,075 & 55,293 \\
\hline \multicolumn{5}{|l|}{$\underline{\text { Controls }}$} \\
\hline BLS Total Employment & $\mathrm{X}$ & $\mathrm{X}$ & $\mathrm{X}$ & $\mathrm{X}$ \\
\hline BLS Unemployment Rate & $\mathrm{X}$ & $\mathrm{X}$ & $\mathrm{X}$ & $\mathrm{X}$ \\
\hline
\end{tabular}

Notes: Outcome data come from Michigan's Unemployment Insurance Agency (UIA). The "window" refers to the length of the evaluation period and indicates the number of quarters before and after the expungement for example, "+/- 2" means a four-quarter (one year) evaluation period, with two quarters before and two quarters after the expungement. The sample period runs from the third quarter of 1997 through the second quarter of 2013. The sample includes quarterly data from individuals who received a known-date expungement between January 1998 and May 2011, did not have an out-of-state driver's license, matched to the UIA data in at least one quarter of the sample period, were of working age (eighteen to sixty-four) for the entire observation period indicated in the column, and received an expungement within their first year of eligibility. Standard errors clustered on the person are reported in parentheses. $+{ }^{*}, * *$, and $* * *$ represent significance at the $10 \%, 5 \%, 1 \%$, and $0.1 \%$ level, respectively. 
employment setback. ${ }^{292}$ Motivation that is longer term rather than specific to the particular time around the expungement is unlikely to confound our results because it would not explain a turnaround in the trend at the time of expungement receipt. Likewise, we worry less about regression to the mean when we study this sample because there is less reason to believe that an individual's choice to apply at the culmination of the waiting period is motivated by finding themselves at the bottom end of a random fluctuation in their employment outcomes; rather, they are simply applying the first chance they get.

The regressions in Table 6, Panels A-C, directly parallel those in Table 5, Panels A-C; we carry out the same analyses on the smaller "pent-up" sample. Table 6 demonstrates very strong gains in employment and wages after receiving an expungement - changes that remain statistically significant $(p<0.00 \mathrm{I}$ for almost all estimates) despite the loss of power accompanying the sample's smaller size. ${ }^{293}$ Early expungement recipients become, by two years after expungement receipt, I.I 2 times as likely to be employed at all using our "any wages" measure (a seven percentage point gain) and I.2 times as likely to be employed for at least \$IOO per month (ten percentage points), and they earn I.24 times their prior wages on average.

The most important difference between these results and our Table 5 findings concerns the pre-expungement underlying trend, which is negative in all Table 5 specifications. By contrast, the early-expungement group exhibits no significant prior trend for most windows and outcome variables, consistent with our theory of pent-up demand. ${ }^{294}$ In other words, the arrival of the five-year threshold for these individuals is effectively random; it does not coincide with any particular pattern in preexpungement employment outcomes. Thus, mean regression cannot explain the subsequent trend changes because there is no prior downturn from which to regress. It is also hard to explain by a job search - there is no prior setback to explain its arrival, and moreover, the timing of the expungement for early recipients seems to be driven mechanically by the

292 Cf. Peter M. Gollwitzer, Mindset Theory of Action Phases, reprinted in I HANDBOOK OF TheORIES OF SOCIAL PSYCHOLOGY 526, 527 (Paul A.M. Van Lange et al. eds., 2012) (explaining that under the Rubicon model for analyzing motivation, a person's course of action may be separated into phases that include a predecision phase - where a person begins setting goals - and a preaction phase - where a person begins goal-directed behaviors).

293 The timing of the largest gains is slightly later (the curves are slightly less steep in the sixmonth window), but by the end of two years, the net gain in proportional terms is essentially identical to what we observe for the broader group in Table 5 .

294 Table 6 offers evidence in support of our causal account of expungement receipt: the flat prior trend, which is followed by a steeply positive post-expungement trend, is inconsistent with earlyexpungement recipients applying for expungement in the wake of an employment downturn. Admittedly, a few of our specifications hint at a small negative pretrend in employment outcomes, but others actually produce positive coefficients on Elapsed, our trend variable. 
eligibility clock. ${ }^{295}$ Perhaps the absence of mean regression and motivation effects slightly dampens the immediate effects we estimate in the shortest time window, but by two years the gains are just as large. This result provides quite good reason to believe that the employment and wage gains are substantially caused by expungement.

In Figure 4, we present a variant of the wage graph from Figure ${ }_{3} \mathrm{C}$; this version, perhaps, provides more compelling visual evidence of the causal explanation of our results. This analysis is limited to the earlyexpungement sample, and it is also residualized - that is, we use regression analysis to remove the underlying downward trends attributable to secular changes in the economy. This graph shows little evidence of any downward trajectory for individual wages before expungement. Rather, it presents a noisy but essentially flat pattern, which abruptly turns upward after expungement receipt. ${ }^{296}$

The results from the early-expungement sample are encouraging in another sense as well: they suggest that similar employment benefits might accrue in states that make expungements automatic after a fixed period of time post-conviction. ${ }^{297}$ One might otherwise worry that the employment gains depend on the fact that expungement recipients like those in our data are a self-selected group who choose to apply just when they are hunting for a job. Even if the expungement does help (that is, it has a causal effect) in obtaining employment or better wages, one would not necessarily expect a similar effect to emerge if a recipient is not job hunting in the first place. ${ }^{298}$

But in the early-expungement sample, the timing of the expungement is less likely to be determined by an individual's search for better employment circumstances; rather, for most of this group, expungement timing is dictated by the arbitrary five-year waiting period. And that perhaps explains why the gains for this group are slightly slower to arrive - but still, they arrive fully within two years of the expungement. If expungement kicked in automatically after five years (or some other time threshold), presumably most recipients would not happen to be looking for a job (or a better-paying job or one with more hours) at that

\footnotetext{
295 See supra notes II5-I24 and accompanying text (describing in detail the eligibility requirements — and in particular the five-year waiting period — for expungement in Michigan).

296 For space reasons, we show only the wage graph here and not the other outcome variables. The graphs of the employment measures, when we construct them using the early expungement sample and residualized, do show a slight decline in the quarters before expungement receipt, but it is much smaller than what we observe for the full sample.

297 For a list of states that have led this policy shift, see supra section I.B, pp. $2472-76$.

298 In other words, we worry that receipt of an expungement might have heterogeneous effects on employment outcomes, depending on whether someone is hunting for a new job, which might be unobservable. $C f$. Patrick Arni \& Amelie Schiprowski, Job Search Requirements, Effort Provision and Labor Market Outcomes, I69 J. PUB. ECON. 65, 75-76 (2019); James J. Heckman \& Edward Vytlacil, Policy-Relevant Treatment Effects, 9I AM. ECON. REV. I07, I07 (200I).
} 


\section{Figure 4. AVERAGE RESIDUALIZED QUARTERLY WAGES BEFORE AND AFTER EXPUNGEMENT}

(Expungement in First-Eligible-Year Subsample)

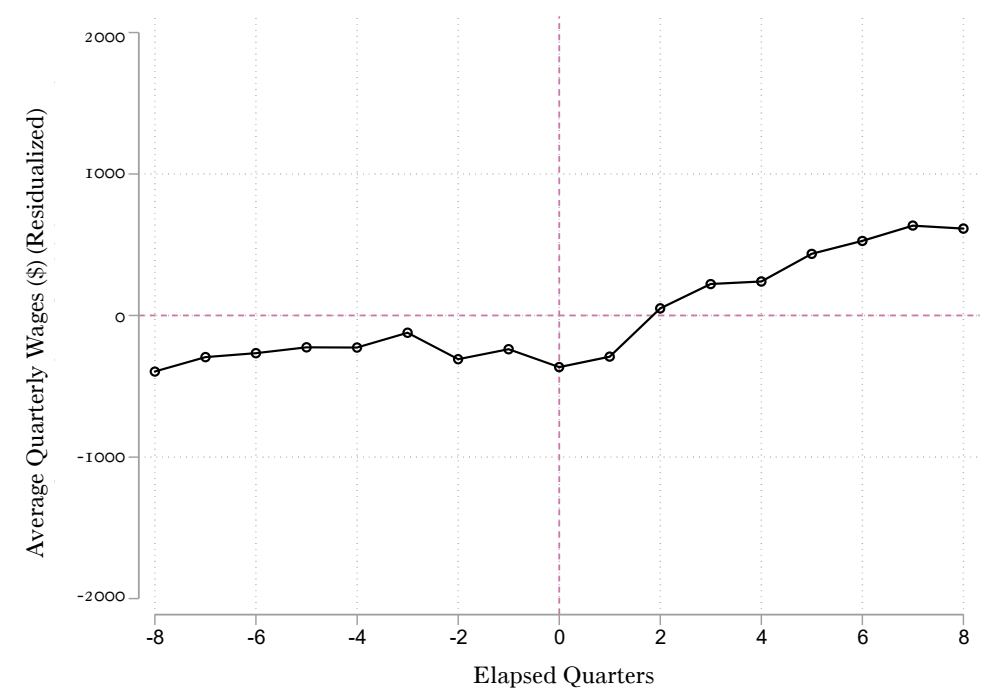

Notes: Quarter I (immediately after the dotted line) is the quarter of expungement receipt. The sample consists of individuals who received a known-date expungement between January I998 and May 20II, did not have an out-ofstate driver's license, matched to our UIA data in at least one quarter during the period from 1997 to 2013 , and were of working age (eighteen to sixty-four).

very time or within moments of learning about their expungement. But almost everyone looks to improve their employment situation eventually - and probably more frequently among people with records, who tend to be in lower-paying jobs with higher turnover. ${ }^{299}$

In sum, the causal interpretation of our results is on all fours with many patterns in our data that are otherwise difficult to explain - and with what we should expect based on extensive research showing that criminal records pose substantial hurdles to employment success. ${ }^{300}$ Our

299 See Adams et al., supra note 95, at 30 ("Respondents, at times, expressed frustration with their inability to gain employment, noting that the limited jobs open to them predominantly involved poor working conditions and low pay ....").

300 See Franklin \& Johnsen, supra note 248, at 736-37; supra section I.A, pp. 2468-7 I. 
findings are consistent with the intuition that expungement of those records should help to reduce those hurdles.

Notably, our analysis is based entirely on expungements received in the age of the internet. ${ }^{301}$ Thus, our results suggest that it is possible for record clearing to generate substantial benefits for individuals with records notwithstanding the search tools currently available to employers. And this, perhaps, should not be surprising. Many arrests and convictions are not especially newsworthy and do not create a long trail of adverse Google hits. ${ }^{302}$ Employers, after all, overwhelmingly pay to carry out background checks using criminal records databases; they do so presumably because they believe that the database they patronize will provide them with much more comprehensive and reliable information than they could otherwise obtain for free. ${ }^{303}$

And Michigan's experience demonstrates that expungement can, in fact, succeed in excising convictions from these databases. ${ }^{304}$ This, too, is probably to be expected under the circumstances. Companies that manage these databases obtain their records from the state and update them frequently; ${ }^{305}$ their legal obligation not to share expunged records

301 Dates range from I998 to $201 \mathrm{I}$, with a median of 2006 . Internet usage was less ubiquitous early in this period, but the gains from expungements are similar (if anything, larger) if one looks only at dates after the median of this span of years, which was well into the period when internetbased background research had become pervasive.

302 See Sara Tiegreen \& Elana Newman, Violence: Comparing Reporting and Reality, DART CTR. FOR JOURNALISM \& TRAUMA (Feb. I8, 2009), https://dartcenter.org/content/violencecomparing-reporting-and-reality [https://perma.cc/ $\left.\mathrm{FX}_{48-4} \mathrm{Y}_{5} 6\right]$ (noting that "[r]eports of crime don't match actual rates of crime" and that less serious crimes receive much less attention from the media). But see Lageson, supra note 96 ("Even if a record is officially wiped clean, it's legal for criminal justice agencies and other websites to keep criminal records online. Arrest records, mug shots, and court records are classified as in the public record in most states.”).

303 One 20 Io survey found that $92 \%$ of employers perform criminal background checks on some potential hires and that $73 \%$ perform criminal background checks on all potential hires. Two years later, this number declined to $86 \%$ of employers conducting criminal background checks for some potential hires and $69 \%$ of employers for all potential hires. SOC'Y FOR HUMAN RES. MGMT., supra note 42 .

304 Michigan criminal records are readily available for direct search by employers and other members of the public via state databases from which expunged records are purged. See Criminal History Records, MICH. ST. POLICE, https://www.michigan.gov/msp/o,4643,7-I 23-I878_ 83 I I---,oo.html [https://perma.cc/4QQB-SML8] (explaining the different kinds of searches available and noting the unavailability of suppressed criminal records); MICH. ST. RECS, https:// michigan.staterecords.org [https://perma.cc/R573-2 $\mathrm{XR}_{3}$ ] (providing a searchable database).

305 See MARINA DuAne ET AL., URBAn InSt., CRIMINAL BACKGROUND CHECKS: IMPACT ON EMPLOYMENT AND RECIDIVISM 7-8 (20I7), https:/www.urban.org/research/ publication/criminal-background-checks-impact-employment-and-recidivism/view/full_report [https://perma.cc/6GWF-SESW]. 
is clear; ${ }^{306}$ and thus failing to observe this requirement potentially exposes them to criminal prosecution. ${ }^{307}$ In all of our conversations with expungement advocates in Michigan, none mentioned any concerns about the practical effectiveness of expungements at limiting employer access to records, even though similar concerns have been raised often in the course of debates about expungement reform elsewhere. ${ }^{308}$

To be sure, our data do not establish that expungement works perfectly in all cases to hide records from the public eye; it is likely that some individuals really cannot escape the digital trail of their prior convictions, and mistakes could well persist for some individuals who have had their records cleared in some criminal history databases. 309 Moreover, a clean record obviously does not automatically translate into a new or better job; the search for employment involves many other factors, and not every expungement recipient will end up experiencing employment benefits (although some will presumably experience benefits in other areas of life as well). The employment and wage gains that we

306 Third-party vendors are less important given the availability of public records, but in any event, they too are constrained by law not to share expunged records - indeed, doing so is a misdemeanor. MICH. COMP. LAWS $§ 780.623(5)$ (2020).

307 See id.

308 Many data collection agencies that offer background checks to companies and employers qualify as consumer reporting agencies (CRAs) that are regulated by the Fair Credit Reporting Act (FCRA). See LOVE ET AL., supra note 6, §§ 5:I4-5:I5, 5:I 9; Roberts, supra note 97, at 345. However, "not all CRAs use reliable sources for their reports, and they certainly do not always update expunged records from their databases through removal. Thus the potential for, and indeed incidents of, error can be high.” Id.; see also REBEcCa VAllas \& SHARON DiETRICH, CTR. FOR Am. Progress, One Strike and You're Out: How We Can Eliminate Barriers to

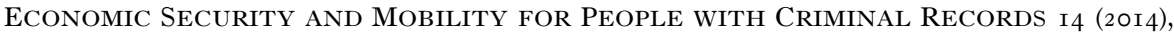
https://cdn.americanprogress.org/wp-content/uploads/20I4/I 2/VallasCriminalRecordsReport.pdf [https://perma.cc/PXV4-ANWP] ("Common errors include reporting mismatches of cases belonging to someone else, reporting expunged cases, and failure to report outcomes of old arrests.”). Jenny Roberts mentions that some states do have their own credit reporting acts, and these are a way of "limiting access to and use of sealed and expunged records." Roberts, supra note 97, at 345. Mugshot websites do not qualify as CRAs and are therefore unregulated by the FCRA. See id. Eldar Haber argues that digital access to records poses a constant threat to record clearing, Haber, supra note 97 , at 356, and expungements "must be revisited and revised to address the challenges of digital technology to rehabilitation," $i d$. at 384 . "'Mugshot' websites post photos from the day's arrests, often free of charge except to those who must pay to get expunged charges taken off the site. Websites like 'Instant Checkmate' encourage a quick check of criminal records and social media before a date." Roberts, supra note 97, at 329 (footnotes omitted). Roberts argues that sealing and expungement laws can be made more effective by "ensuring the accuracy of records, restricting ways in which decision makers with access can use records, and effective regulation of background screening companies and private companies that sell mugshots and other arrest and conviction information." Id. at 344. Clay Calvert and Jerry Bruno argue that journalists are positioned to balance the competing interests of expungement laws and the First Amendment guarantee of a free press: "[I]f a newspaper publishes a story regarding the arrest of an individual, then it takes on an ethical obligation to subsequently report on the expunction of that same individual's record should such a resolution occur." Calvert \& Bruno, supra note 97, at 143-44.

309 See supra notes $96-97$ and accompanying text. 
find are averages for expungement recipients as a group, and to the extent that they can be interpreted as causal effects, they represent achievable gains even if expungement does not work flawlessly.

\section{OTHER OBJECTIONS TO EXPUNGEMENT LAWS}

This Article does not seek to address comprehensively all policy concerns surrounding reform of expungement laws. Some arguments raised by both proponents and opponents do not depend on empirical claims and are not subject to evaluation by data-driven studies like ours. For example, expungement advocates often argue that people who have completed their sentences following a conviction deserve a second chance and should not be punished and stigmatized forever. ${ }^{310}$ The case for a "clean slate" is sometimes framed in terms of forgiveness and redemption, language that, as we note above, alludes to various religious traditions. ${ }^{311}$ The affirmative case for expungement reform can also be framed in terms of equality, as seeking to help people with records escape the permanent form of second-class citizenship that effectively results from the collateral consequences of convictions. ${ }^{312}$ At the same time, some expungement opponents contend that sealing records (and allowing people who have been convicted of crimes to explicitly state the opposite) is dishonest and at odds with freedom of information, government transparency, and the public's right to know. ${ }^{313}$

310 See, e.g., NAT'L ASS'N OF CRiminal Def. Lawyers, Collateral Damage: AMERICA's FAILURE TO FORGIVE OR FORGET IN THE WAR ON CRIME I 2-I3, I5-I8 (2OI4), https://www.nacdl.org/getattachment/4aIf 6 6cd-ec82-44fi-ao93-798ee Icd 7 ba3/collateral-damageamerica-s-failure-to-forgive-or-forget-in-the-war-on-crime-a-roadmap-to-restore-rights-andstatus-after-arrest-or-conviction.pdf [https://perma.cc/EL 3 N-LHU 4 ] [hereinafter COLLATERAL DAMAGE]; VALLAS \& DieTRICH, supra note 308 , at $34,37,49$.

311 See, e.g., VAlLAS \& DiETRICH, supra note 308, at 34 ("Enabling Americans with criminal records to obtain a clean slate upon rehabilitation would permit them to redeem themselves and move on with their lives after they pay their debt to society."); supra note 238 and accompanying text.

312 E.g., COllateral DAMAGE, supra note 310, at 9 ("[C]ollateral consequences, whether based on specific legal provisions or the general discrimination they encourage, have produced untold collateral damage in the war on crime. Collateral consequences affect jobs and licenses, housing, public benefits, voting rights, judicial rights, parental rights, the right to bear arms, immigration status, and even volunteer opportunities. Each individual consequence may have seemed prudent and logical when enacted, but their overall effect is to consign millions to second-class status."); Beth Feldstein, The Steep Price of a Clean Slate, EQUAL Just. Under L. (June 20, 20I9), https://equaljusticeunderlaw.org/thejusticereport/the-steep-price-of-a-clean-slate [https://perma.cc/9JFM-D68Y] ("[O]ur laws perpetuate a cycle of poverty where financially-struggling people with criminal records are stuck as second-class citizens."); Eric Westervelt \& Barbara Brosher, Scrubbing the Past to Give Those with a Criminal Record a Second Chance, NPR (Feb. I9, 2019, 4:58 AM), https://www. npr.org/20I 9/o2/I 9/692322 738/scrubbing-the-past-to-give-those-with-a-criminal-record-a-secondchance [https://perma.cc/68EJ-56WH] ("With background checks ubiquitous for jobs, schools, mortgage applications and more, even one conviction — and sometimes even just one arrest — can dog people for years, critics say, relegating them to permanent second-class status.")

313 See Funk, supra note 94, at 302-04 (arguing that aggressive expungement policies hamper police investigations and present a risk of liability or theft to employers); see also JACOBS, supra note 7 , at 302 
These arguments essentially involve questions of principle, values, and preferences, not data or empirics, and fully engaging them is beyond our Article's scope. Instead, in this Part, we briefly address two other possible objections to expungement laws that do connect more directly to the substance of our evidence and argument: the crime and labor-market consequences of expungement laws.

\section{A. General Deterrence}

When evaluating the effects of expungement on crime, one might object that our focus on subsequent recidivism rates of expungement recipients is incomplete. Record-clearing policies can influence crime rates through other channels - in particular general deterrence, especially of those who do not presently have records. Perhaps some people are deterred from committing crimes by the knowledge of the many ways in which having a criminal record might harm them, such as embarrassing them in their communities or interfering with their future employment and housing prospects. ${ }^{314}$ The concern, therefore, is that expanding expungement opportunities (especially through a much broader and/or automatic expungement policy) may conflict with general deterrence that is, deterrent effects on the population as a whole - and do so in a way that produces a net increase in crime.

Such a consequence is theoretically possible, but once we inspect the argument's basic premises, we are skeptical of it. Our study does not evaluate general deterrence effects, nor has any study of expungement laws. ${ }^{315}$ But other existing research provides many reasons to expect

("First Amendment purists and open government advocates ... argue that when it comes to combatting crime, criminal justice agencies and courts do a better and fairer job of preventing and solving crime when they have more information at their disposal."); Alessandro Corda, More Justice and Less Harm: Reinventing Access to Criminal History Records, 60 How. L.J. I, 36 (2016).

314 See Eric Rasmusen, Stigma and Self-Fulfilling Expectations of Criminality, 39 J.L. \& ECON. 519, 532-36 (1996) (arguing conviction stigma may contribute to deterrence). But see Murat C. Mungan, Stigma Dilution and Over-criminalization, I8 AM. L. \& ECON. REv. 88, 88 (2016) ("Criminalizing an act that provides weak signals about a person's productivity and character can dilute the stigma attached to having a criminal record."). Indeed, this possibility has been raised in the context of sex offender community notification laws, and there is at least some evidence that concern over being publicly labelled as a "sex offender" might reduce the number of first-time offenses, although the evidence, even in this context, is mixed. See Prescott \& Rockoff, supra note 254 , at I8I (finding some evidence that community notification may reduce the frequency of first-time sex offenses but also that it may exacerbate recidivism among those subject to it).

315 Recently, there has been some experimental research on record expungement, however. See Romain Espinosa et al., The General Versus Specific Deterrence Effects of Expungements: Experimental Evidence I-3 (George Mason Univ., Law \& Econ. Research Paper No. I9-IO, 20I9), https://ssrn.com/abstract=337970I [https://perma.cc/LGF $7-9 \mathrm{C} 6 \mathrm{~J}]$ (reporting results from a lab experiment on expungement and its influence on criminal behavior and suggesting that the effect of expungements on general deterrence varies based on cost but that "[t]here is no effect of expungements on specific deterrence," $i d$. at I). 
such effects to be minimal (at least when the record-clearing laws in question are similar to those most states have in place or are presently considering). If anything, they are very likely to be outweighed by salutary specific deterrence effects on those who already have records.

First, general deterrence effects are relevant only if potential offenders are not only aware of the collateral consequences of criminal convictions, ${ }^{316}$ but also cognizant of the availability of expungement. But even people who already have criminal records and are legally eligible for expungement under existing record-clearing laws rarely know about or understand the opportunity. We doubt that - even if broader laws were enacted - general public knowledge of it would be particularly widespread, especially prior to a criminal conviction. ${ }^{317}$ Similarly, studies of the effects of other legal shocks on general criminal deterrence emphasize that deterrence depends on perceived consequences, not actual ones, ${ }^{318}$ and they stress that most people do not have a very good understanding of the law that governs them, a phenomenon that tends to undermine deterrence effects. ${ }^{319}$ Even in a world without record clearing, individuals considering committing crimes may be overoptimistic when thinking about potential labor-market and other collateral consequences. They may be unaware of many of those consequences and also dismiss the likelihood of getting caught.

Second, the existence of waiting periods ought to almost completely eliminate general deterrence concerns. This is especially so for fairly long waiting periods, like Michigan's current five years, and even more so for the up-to-ten years the new Pennsylvania and Utah automatic expungement laws require. ${ }^{320}$ It might be less true where waiting periods are shorter, such as under California's new law, but even in that case, the law requires an individual to at least complete their sentence, delaying the availability of expungement. ${ }^{321}$

316 See Rasmusen, supra note 3I4, at 520; see also Murat C. Mungan, Gateway Crimes, 68 ALA. L. REV. 67I, 68I (20I7) ("Both stigma and formal sanctions have the desirable effect of increasing the expected cost" - that is, a cost assumed to be accurately predicted in advance — "to committing crime and thereby reducing people's incentives to commit crimes.").

317 See supra section II.C, pp. 250I-IO.

318 See Daniel S. Nagin, Criminal Deterrence Research at the Outset of the Twenty-First Century, 23 CRIME \& JUST. I, 5 ( I998) ("The perceptual deterrence literature was spawned by the recognition that deterrence is ultimately a perceptual phenomenon. While great effort has been committed to analyzing the links between sanction risk perceptions and behavior, comparatively little attention has been given to examining the origins of risk perceptions and their connection to actual sanction policy."); see also Aaron Chalfin \& Justin McCrary, Criminal Deterrence: A Review of the Literature, 55 J. ECON. LiterATURE 5, IO-I 2 (20I7).

319 See Robert Apel, Sanctions, Perceptions, and Crime: Implications for Criminal Deterrence, $29 \mathrm{~J}$. QUANTITATIVE CRIMINOLOGY 67, 78-79 (2013); Chalfin \& McCrary, supra note 318, at IO-I I

320 See Mich. COMP. LAWs $\S 780.62$ I(5) (2020); I8 PA. CONS. STAT. § 9I 22.2 (a) (20I9); UTAH CODE ANN. § 77-40-IO5(3)(c)(i) (West 2020).

321 See Cal. Penal CODE $\S$ I $203.425(\mathrm{a})(2)(\mathrm{E})$ (West 2020). 
Intuitively, we have a hard time imagining the potential offenders who would (absent expungement) avoid committing a crime out of fear of social stigma, job loss, or other collateral consequences, but who would decide to commit the crime after all if they became aware that five or ten years later they might, if they keep their record clean and are otherwise eligible, be relieved of some of those consequences. ${ }^{322}$ This possibility seems especially unlikely under a petition-based regime involving uncertain judicial discretion. What is far more likely to be salient to these potential offenders is the immediate consequence of losing the job they have now, or embarrassing themselves or their families now (in addition to the sentencing consequences). The possibility of expungement many years down the road is comparatively remote and indefinite, and even at best it does not undo many of those consequences; it simply stops them from continuing to accrue over time.

Support for this intuition derives from the substantial literature addressing the effects of differences or changes in expected sentences on crime rates. ${ }^{323}$ In general, this research finds that criminal behavior is not particularly sensitive to changes in the expected sentence, especially not to additional years of incarceration beyond the first few. ${ }^{324}$ Research instead indicates that deterrence is best achieved through certainty and celerity of punishment - for example, by visibly increasing policing. ${ }^{325}$ Partly, this failure of deterrence is a function of people not understanding the relevant laws, but it is also because most people have high, even hyperbolic, "discount rates" — we simply do not care nearly as much about things that will happen to us years from now as we do about things that

\footnotetext{
322 In support of our conjecture, research indicates that individuals living in states that decriminalize marijuana often remain - at least for a time - not fully aware of the change in the law. Rather, they continue to believe that they could be jailed for marijuana possession. Robert MacCoun et al., Do Citizens Know Whether Their State Has Decriminalized Marijuana? Assessing the Perceptual Component of Deterrence Theory, 5 REV. L. \& ECON. 347, 366-67 (2009).

323 See Chalfin \& McCrary, supra note 318, at 5-6, 24-28 (providing an excellent recent review of the literature); J.J. Prescott, Criminal Sanctions and Deterrence, in I ENCYCLOPEDIA OF LAW AND ECONOMICS 498, 508-09 (Alain Marciano \& Giovanni Battista Ramello eds., 20I9).

324 See, e.g., Marc Mauer, Long-Term Sentences: Time to Reconsider the Scale of Punishment, 87 UMKC L. Rev. II3, I23 (20I8); Michael Tonry, An Honest Politician's Guide to Deterrence: Certainty, Severity, Celerity, and Parsimony, in 23 Deterrence, Choice, And Crime 365, 365 (Daniel S. Nagin et al. eds, 2018); Giovanni Mastrobuoni \& David Rivers, Criminal Discount Factors and Deterrence I (Inst. of Labor Econ., Discussion Paper No. 9769, 20I6), https:// papers.ssrn.com/sol $3 /$ papers.cfm?abstract_id=2730969 [https://perma.cc/ZN8M-FHWZ] ("Our estimates imply that the majority of deterrence is derived from the first few years in prison.”). But see, e.g., Francesco Drago, Roberto Galbiati \& Pietro Vertova, The Deterrent Effects of Prison: Evidence from a Natural Experiment, I 7 J. POL. ECON. 257, 259-60, 267-73 (2009).

325 See Chalfin \& McCrary, supra note 318, at 5 ("[T]here is considerable evidence that crime is responsive to police ....”).
} 
will happen today. ${ }^{326}$ This basic feature of human psychology, which may be even more present in lawbreakers, ${ }^{327}$ has been documented in wide-ranging contexts. ${ }^{328}$ And its pervasiveness strongly implies that the possibility of an expungement years later is unlikely to sway a person's decision to commit a crime today. ${ }^{329}$ Furthermore, even beyond the effects of the waiting period's implicit delay, scholarship on general deterrence suggests that people are simply less responsive to the consequences of being caught for a crime in the first place than one might expect based on traditional economic theory. 330

Third, if one broadens the analysis to encompass general deterrence effects, it also makes sense to take into account yet another channel by which expungement might influence crime: the specific deterrence of potential expungement recipients. That is, one must consider how the possibility of expungement affects the incentives of the many people who already have criminal records, not just those who are contemplating the commission of first offenses. ${ }^{331}$ After all, most crime is committed by repeat offenders. And these effects, intuitively, cut in the opposite direction - and not just after expungement, which is the subject of our recidivism discussion in Part III. Just about every state that makes expungement available conditions it on some period of good behavior - which creates incentives for good behavior before the waiting period expires. ${ }^{332}$ To be sure, such effects have not been studied either, and they too depend on potential offenders knowing about the expungement law and caring about the consequences of a clean record. But even though knowledge of expungement laws is limited even among this subpopulation, people who are already convicted and potentially expungement-eligible are, intuitively, at least somewhat more likely than members of the general public to be aware of such policies and to consider their benefits germane to

326 See Chae Mamayek et al., Temporal Discounting, Present Orientation, and Criminal Deterrence, in THE OXFORD HANDBOOK OF OFFENDER DECISION MAKING 209, $2 \mathrm{I} 4-\mathrm{I} 5$ (Wim Bernasco et al. eds., 20I 7 ).

327 See David Åkerlund et al., Time Discounting and Criminal Behavior, I I3 PNAS 6I60, 6I60 (2016).

328 Murat Yilmaz, An Extended Survey of Time-Inconsistency and Its Applications, 32 BOĞAZIÇI J. REv. SOC., ECON. \& ADMIN. STUD. 55, 56-58 (20I8).

329 J.J. Prescott and Jonah Rockoff, supra note 254 , do find some evidence that the possibility of becoming a publicly registered sex offender many years in the future can deter first-time sex offenses, see id. at I8I. However, inclusion on a sex offender registry is an unusually well-known and widely feared collateral consequence; Prescott, supra note 253 , observes that other collateral consequences (and even sentencing consequences such as those we discuss here) are likely less salient to potential offenders, see id. at ro40.

330 See Chalfin \& McCrary, supra note 318, at 37-40.

331 See Michael Mueller-Smith \& Kevin T. Schnepel, Diversion in the Criminal Justice System: Regression Discontinuity Evidence on Court Deferrals 3-6 (Aug. 3, 2017) (unpublished manuscript), https://sites.lsa.umich.edu/mgms/wp-content/uploads/sites/283/20I 7/08/Diversion_in_the_Criminal_ Justice_System.pdf [https://perma.cc/F98G-SGCH]

332 It might be possible to strengthen incentives for ongoing good behavior by providing that a subsequent conviction following an expungement could lead to the unsealing of a previously sealed conviction. See Devah PAGER, MARKEd: RACE, CRIME, AND Finding Work IN AN ERA OF MASS INCARCERATION I56-57 (2007). 
their decision making. After all, these people are living at that moment with the often-significant collateral consequences of their records; if they are struggling to find a job or housing, the possibility that another clean year or two could entitle them to an expungement might be much more salient to them than expungement opportunities are to the general public.

Finally, it bears noting that the theoretical possibility that general deterrence of criminal behavior might decrease in a world with expungement is an argument that, at its logical extreme, can be deployed against any reform meant to reduce the harshness of the criminal justice system's consequences. But it cannot be the case that anything that makes the lives of people with records worse is better; this notion is at odds with all reentry efforts and all policy-based limits on punitiveness. At some point, the costs of such an approach to individuals and communities outweigh the benefits. In this case, the purported general deterrence concern is purely theoretical, tentative at best, and fragile on its own terms. Absent strong evidence supporting its practical importance in the expungement context, policymakers ought to give the general deterrence argument very little weight.

\section{B. Statistical Discrimination or Stereotyping}

A different objection relates to the potential unintended labormarket consequences of expungement laws. The precise worry is that if employers really do not want to hire people with criminal records, walling off information about applicants' records will simply cause them to pursue that objective in other, potentially more pernicious ways. Specifically, employers might instead rely more heavily on perceived proxies for criminal records, such as race - which could amplify racial disparities in employment. ${ }^{333}$ This phenomenon is referred to as statistical discrimination, or - if employers' assumptions about who has criminal records are inaccurate or exaggerated - stereotyping. ${ }^{334}$

The strongest empirical support for this concern comes from recent research by one of us on the effects of Ban-the-Box laws. In a large, randomized field experiment that varied the race of fictitious job applicants, Agan and Starr find that after Ban-the-Box went into effect in two

333 See Jennifer L. Doleac \& Benjamin Hansen, The Unintended Consequences of "Ban the Box": Statistical Discrimination and Employment Outcomes when Criminal Histories Are Hidden, $38 \mathrm{~J}$. LAB. ECON. 32 I, 324-26 (2020).

334 See generally Kevin Lang \& Jee-Yeon K. Lehmann, Racial Discrimination in the Labor Market: Theory and Empirics, 50 J. ECON. LITERATURE 959, 985-98 (20I2). Landlords and other decision makers could in theory have similar responses, although we focus our discussion here on employment. See, e.g., David Bjerk, Racial Profiling, Statistical Discrimination, and the Effect of a Colorblind Policy on the Crime Rate, 9 J. PUB. ECON. THEORY 52 I, 522 (2007). 
jurisdictions, white applicants' advantage in receiving callbacks from affected employers skyrocketed by more than a factor of six. ${ }^{335}$ These findings suggest that large numbers of employers appear simply to assume that most or at least many black applicants have criminal records. Understandably, we are often asked whether we ought to expect expungement laws to have a similar effect.

This question is legitimate and worthy of study in the future; we are aware of no empirical evidence on this concern yet. But we believe that at least under the vast majority of current and proposed expungement policies, there is little reason to fear a substantial increase in racial discrimination. An important difference between expungement and Banthe-Box restrictions is that Ban-the-Box explicitly takes away all criminal record information on all applicants, at least during the early stages of the hiring process, when significant screening occurs. ${ }^{336}$ Employers reviewing applications are left completely in the dark as to who has a criminal record - even as to very serious, very long, and very recent criminal records. Expungement policies, in contrast, are much more targeted in their approach; most conviction records will never be expunged, and recent (and thus much more informative) records categorically cannot be expunged under the law in most states. Moreover, in a jurisdiction with an expungement law, employers can collect information on criminal records, and anybody with a non-expunged record can be required to provide that information.

So employers under an expungement policy still have access to a lot of information about criminal history; this should reduce their incentive to rely on factors like race as a proxy for it. In Michigan, for instance, if an employer sees that an applicant reports having no record, it is vanishingly unlikely at present that the applicant actually has an expunged record; there are ten million people in Michigan, and only around thirty thousand expungement recipients. Even if expungement were made automatic, expanding the size of the latter group substantially, it would still be fairly unlikely for any particular applicant to have received an expungement. ${ }^{337}$ Moreover, even if the applicant does have an expunged record, at worst, it would be an old and likely less serious one, followed

\footnotetext{
335 See Agan \& Starr, Ban the Box, supra note 39, at I9I.

336 See Doleac \& Hansen, supra note 333, at 323-24 ("Even though ex-offenders could be weeded out after the interview process, interviewing candidates is costly. Employers would rather not spend time interviewing candidates who they are sure to reject when their criminal history is revealed." (footnote omitted)).

337 See Amy Shlosberg et al., Expungement and Post-exoneration Offending, I04 J. CRIM. L. \& CRIMINOLOGY 353, 355-62 (2014) (surveying state and federal expungement policies and noting how few crimes are eligible for expungement).
} 
by years of nonrecidivism, given the waiting period and eligibility requirements. ${ }^{338}$ This possibility provides little incentive for employers to engage in statistical discrimination.

What's more, all of this assumes employers know expungement laws exist at all. Ban-the-Box laws have been very salient to employers, who were forced to change their applications and were mandated to refrain from asking about something that had always been a traditional part of their process. ${ }^{339}$ Expungement law is not salient in the same way. Employers need do nothing, and they can continue to ask the questions (and run the background checks) that they always have. And, if most people with expungeable records are unaware of record-clearing opportunities, it seems very likely that many employers will be in the dark about them as well.

All of that said, there can be no doubt that the landscape of expungement reform is changing, and the more sweeping expungement policies become, the more reason there will be to worry about the possibility of statistical discrimination by decision makers. If an expungement policy is so broad that it leaves employers effectively without much useful criminal record information at all, they might indeed react much as employers do to Ban-the-Box policies. Among current expungement laws, California's may come closest to raising this concern, since it appears to apply to a broad swath of criminal offenses, albeit relatively minor ones, and has (for some crimes) no post-sentence waiting period. ${ }^{340}$ Therefore, the effect of this and similarly expansive laws on racial discrimination is worth assessing via future research.

\section{CONCLUSION}

As states throughout the country continue to debate the adoption and expansion of expungement laws, it is important for their decisionmaking to be guided not by hype or supposition, but by empirical evidence. Prior to the work we present in this Article, policymakers have had very little at their disposal. Fortunately, Michigan's experience with expungement provides a great opportunity to evaluate how these laws work in practice and what their consequences are likely to be. The challenges faced by people with records in Michigan are fundamentally similar to those faced by their counterparts in other states, and many features of Michigan's law - for example, its coverage of felonies and violent crimes and its

\footnotetext{
338 See Pager, supra note 30, at 963 (noting that employers may sometimes only ask about incarceration within the past year); Kathy Gurchiek, Research: Employers Willing to Overlook a Criminal Record to Hire the Right Person, SHRM (May I 7, 2018), https://www.shrm.org/resourcesandtools/hrtopics/behavioral-competencies/global-and-cultural-effectiveness/pages/research-employers-willingto-overlook-criminal-record-to-hire-right-person.aspx [https://perma.cc/ $\mathrm{U}_{3} \mathrm{Z}_{3}-7 \mathrm{~B}_{92}$ ] (reporting survey data showing that employers are less worried about — and therefore relatively more likely to hire individuals with the kinds of records that expungement laws typically address).

339 See Hanks, supra note 83.

340 See CAL. PENAL CoDE $\S \mathrm{I} 203.425(\mathrm{a})(2)(\mathrm{E})(\mathrm{i})$ (West 2020).
} 
middle-of-the-road waiting period - make the state's experience with expungement particularly relevant to assessing the likely effects of reforms nationwide. We hope the findings we document in this study, the first of its kind, will provide helpful guidance for those crucial policy decisions.

Taken together, our findings strongly support increasing the availability of expungement - and particularly efforts to make expungements automatic, or at least procedurally easy to obtain. Those whose records are expunged experience large gains in employment rates and wages and while some of these gains may have their source in other factors such as underlying motivation, expungements very likely cause a substantial portion of these improvements. The expungement effects we uncover imply that record clearing compares favorably as a strategy to other policy interventions that seek to improve employment outcomes. Take, for example, job training - a common public investment. A meta-analysis of thirty-one studies covering fifteen different publicly funded job-training programs finds average unweighted gains in annual wages of $\$ 832$ for women and $\$ 47 \mathrm{I}$ for men. ${ }^{341}$ Like expungement recipients in Michigan, participants in these programs were self-selected; they pursued the programs because they thought they would benefit from them. And they did benefit - but not nearly as much as expungement recipients do (annualized, the wage gains for our sample come to $\$ 4594$ for women and $\$ 4295$ for men). ${ }^{342}$ Meanwhile, the average cost of these jobtraining programs to the government was $\$ 6600$ per person. ${ }^{343}$ Expungement, in contrast, has comparatively minimal costs (running a background check, holding a court hearing, processing the paperwork), ${ }^{344}$ and

341 David H. Greenberg et al., A Meta-Analysis of Government-Sponsored Training Programs, 57 INDUS. \& LAB. REL. REV. 3I, 42 (2003) (reporting weighted means across studies).

342 The job-training study reports results in I 999 dollars, $i d$. at 33, whereas our figures are nominal gains over one-year periods falling between I 997 to $20 \mathrm{II}$, with a median year of 2005 . Adjusting the job-training averages to 2005 dollars comes to $\$$ I6I I for women and $\$ 373$ for men.

343 Id. at 50.

344 For example, the cost of ink fingerprinting, one of the procedure's requirements, is \$15 at the Washtenaw County Sheriff's Office. Fee Schedule, SherifF's OfF. WASHTENAW County MICH., (effective Jan. 4, 20I9), https://www.washtenaw.org/I533/Fee-Schedule [https://perma.cc/ $\mathrm{YMF}_{9-92} \mathrm{~B}$ ]. Certified records in Washtenaw County are \$1 plus \$I per page. Records Request, Trial Ct. Washtenaw County Mich., https://www.washtenaw.org/I420/Records-Request [https://perma.cc/LBS4-GDPX]. In Jackson, Michigan, "United Way of Jackson County [wrote] $\$ 50$ checks to cover the cost of sending paperwork to the Michigan State Police and $\$$ io checks to cover the cost of retrieving official court documents for individuals trying to set aside their record." McLaren, supra note i 96 . One hidden cost is the cost of hiring an attorney to help convince a judge to grant the expungement request: "[A]n expungement can be between $\$ \mathrm{I}, 000$ to $\$ 2,500$, although it can be done without an attorney." Jameson Cook, State Makes It Easier to Expunge Prior Convictions, OAKLAND PRESS (Mar. I7, 20I5), https://www.theoaklandpress.com/news/nation-world-news/statemakes-\%2oit-easier-to-expunge-prior-convictions/article_74afe689-de8a-554c-bcoo-

2 dec2 $46 \mathrm{~d}_{4}$ oc5.html [https://perma.cc/8 $\left.\mathrm{TY}_{3}-\mathrm{FVJ}_{4}\right]$. 
these could very likely be reduced much further if the process were simplified or automated. As an employment intervention, therefore, expungement appears superior to job training in terms of both its effectiveness and its price tag.

The arguments of expungement opponents do not typically focus on program expenditures, of course, but rather on public safety. ${ }^{345}$ Fortunately, our findings on the crime front are equally encouraging. Subsequent offending rates after expungement are extremely low. Ninety-nine percent of those who receive expungements in Michigan are not convicted of a felony anytime in the next five years; $99.4 \%$ are not convicted of any violent crime; and $95.8 \%$ are not convicted of any crime at all, even a petty misdemeanor. In fact, expungement recipients appear to be lower risk than the general public. To be sure, recidivism rates would not be as low if states made expungement available immediately following the completion of a sentence, removed judicial discretion, or extended it to a generally riskier pool, such as people with more extensive criminal records. But even in those scenarios, there is still no evidence to suggest that access to expungement would increase the recidivism risk of those groups; if anything, due to the benefits we find in terms of employment outcomes (and possible benefits in other areas), one should probably expect their recidivism rates to decline.

The discouraging element of our findings is that, despite the apparent benefits of expungement, very few people - even among those who are eligible - actually obtain them. Our best estimate is that $6.5 \%$ of people who meet the legal requirements for expungement in Michigan obtain one within five years - a small fraction of what is already a small fraction of all those living with records, given the tight eligibility requirements. This low uptake rate is troubling, but not shocking, given the procedural hurdles and expenses involved, the lack of legal counsel, the dearth of public information, and the fact that most people with records have limited resources for overcoming these challenges. Unfortunately, all but a handful of states with expungement laws require individuals to apply for relief and give judges the discretion to deny them, so the situation is unlikely to be better in other states. ${ }^{346}$

345 "The most potent argument for broad access to criminal history data is to preserve public safety. The right to a safe and peaceful environment is a core value for a civilized society, and employers cannot allow known dangers in the workplace." Cynthia Diane Stephens, Keeping an Arrest from Resulting in a Life Sentence in an Age of Full Disclosure of Criminal Records, MICH. B.J., Nov. 2008, at 29, 3I. But see Doe v. United States, I Iо F. Supp. 3d 448, 452 (E.D.N.Y. 20I5) ("Simply put, the public safety is better served when people with criminal convictions are able to participate as productive members of society by working and paying taxes.").

346 See CCRC State Survey, supra note I I. For examples of the pitfalls in the application process, see Simone Ispa-Landa, Believing in a Positive Future as a Form of Stigma Resistance: Narratives of Denied Expungement-Seekers, 40 DEVIANT BEHAV. I428, I435 (2019). 
The policy upshot of our research is clear: the process of obtaining expungement should be made as simple as possible, or ideally automatic once an individual's record meets the legal requirements. The pathbreaking Pennsylvania automatic-sealing law, while still at the forefront of developing legislation, has illustrated a way forward; indeed, California's, Utah's, and New Jersey's newly adopted automatic expungement policies are further dramatic advances. ${ }^{347}$ With luck, the next wave of Clean Slate legislation will continue to move in this direction. ${ }^{348}$

Pennsylvania's law is a watershed in terms of expungement procedure, but it is unfortunately quite limited in its substantive scope (that is, in terms of its eligibility rules): automatic expungement applies only to people with minor, nonviolent misdemeanors after ten crime-free years. ${ }^{349}$ Other earlier adopters are less limited on a few dimensions, but not on many and not by much. Presumably, Pennsylvania clean-slate advocates concluded that the bill's substantive constraints were politically necessary to secure automatic process. ${ }^{350}$ Likely, this limitation was meant to defuse the concern that people with more substantial or more recent convictions posed a greater public-safety risk. But our findings

347 See Sharon Dietrich \& Rebecca Vallas, The Left, the Right, and the Football Players: How Clean Slate Automated Sealing Was Passed in Pennsylvania, Clearinghouse Community, (Nov. 20I8), https://www.povertylaw.org/clearinghouse/stories/dietrich_vallas [https://perma.cc/ TE6D-AFJE] ("Pennsylvania catapulted to the forefront of record clearing, becoming the first state in the nation to adopt a groundbreaking new innovation: automated sealing of minor records by use of technology - a concept known as 'Clean Slate.'”); supra note I6 and accompanying text.

348 One factor that makes automatic expungement laws technologically feasible, though, is an orderly records system that transmits records easily from judicial districts to a central office. See Maura Ewing, Simplifying How the Courts Seal Criminal Records, THE ATLANTIC (Apr. 6, 20I 7 ), https://www.theatlantic.com/politics/archive/201 7/04/simplifying-how-the-courts-seal-criminalrecords/52I964 [https://perma.cc/N6ER-TKMR]. States like Michigan and Pennsylvania are primed for ambitious reforms because of their centralized record-keeping systems, while most other states have "siloed" systems that do not transmit records from one court to another. Id. Recordkeeping systems (and the infrastructure they require) are an additional hurdle that states without centralized systems should consider in crafting their reforms.

349 I8 PA. CONS. STAT. § 91 22.2 (2018).

350 For example, those with past felony convictions, multiple first-degree misdemeanor convictions, and four or more second-degree misdemeanors are not eligible for automatic sealing. Mark Scolforo, Wolf Signs Bill Sealing Some Criminal Records After Decade, Associated PRESS (June 28, 2018),

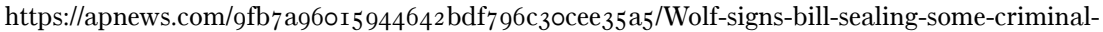

records-after-decade [https://perma.cc/Z $\left.{ }_{2} \mathrm{QF}-8 \mathrm{EBJ}\right]$. See also Dietrich \& Vallas, supra note 347 , for a description of the political compromises the bill made: "The bill . . expanded sealing eligibility to reach first-degree misdemeanors. Although a modest expansion, this was the most that appeared politically feasible, given that misdemeanor sealing had just been introduced by Act 5 earlier in 20I6." Id. District attorney support was vital to the passing of the law, leading to more exclusions in the bill: "Critical stakeholders we needed on board — or at least to remain neutral — were the district attorneys, from whom opposition on a record-clearing bill in Pennsylvania was likely enough to kill it. One major area of focus for them and others was which criminal records would be eligible for sealing both through Clean Slate and through expanded eligibility for filing by petition, and the list of exclusions became longer as we brought them and other key parties on board." Id. 
indicate that these concerns are unfounded; people who receive expungements after just five years pose a very low recidivism risk, even though Michigan does not exclude people with felonies or violent offenses. ${ }^{351}$ The somewhat broader approaches now being pursued in states like California - and perhaps soon in Michigan as well - are more ambitious, and studying their effects will help us to learn more about what happens when expungement is granted broadly and automatically, and not to a narrow, self-selected sample.

For now, however, it is likely that most states will continue to require an application-based, discretionary procedure for at least some subsets of expungement applicants. Where this is so, policymakers should consider how to at least render that process as easy and accommodating as possible. Courts, public defenders' offices, or prosecutors' offices could automatically notify individuals, after the requisite waiting period, that they may be eligible for expungement, and provide them with links to online tools for determining eligibility. Court hearings should not be necessary, especially when prosecutors and victims do not oppose expungements. Online applications should be permitted. Serving the application on multiple entities (the court, the prosecution, the police) should not be required, given that the information could be passed along automatically via computerized processes. Fingerprinting may be essential for background checks (although this too perhaps could be done via touchscreen), but there is no reason an applicant should have to make a fingerprinting visit to a police station and multiple courthouse visits, not to mention a possible visit to a notary. For example, the court clerk's office should be set up to provide whatever records are necessary, provide the form or a computer terminal, take the fingerprints, and collect the forms all at once. Fees should be eliminated; they are minor in their impact on the public fisc (especially given the cost-effectiveness of expungements at improving employment outcomes), but they remain substantial barriers for many people with records.

Long after they have served their sentences, tens of millions of Americans and their families face the serious challenges of life with a criminal conviction record, and this number increases daily. Collectively, these challenges contribute to many significant public policy concerns, making it harder for these families to avoid poverty and contributing to racial disparities in employment and other domains. Our empirical results suggest that expungement is a powerful policy lever for redressing these negative consequences, without risk (and possibly with benefits) to public safety. But expungement will only realize its full potential and

351 See supra Part III, pp. 25 IO-23 (describing the low recidivism rates for expungement recipients despite Michigan allowing expungements for those with violent felony convictions); see also MICH. COMP. LAWS $§ 780.62$ I(3) (2020) (allowing expungements for those with one felony conviction, with the exceptions of sex offenses that are subject to registration requirements and offenses carrying potential life-imprisonment terms). 
make a serious dent in these large-scale social problems if we make it available much more broadly and much more easily. Legislatures throughout the country have been taking up the issue, which provides reason for optimism. They should now consider the empirical evidence, which makes a clear case for action. 